\title{
Site Selection and Evaluation Studies of the Waste Isolation Pilot Plant (WIPP), Los Medaños, Eddy Coúnty, NM
}

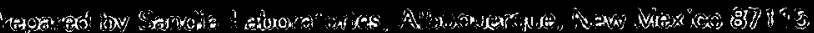

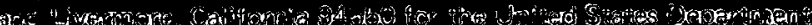

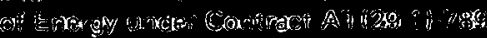

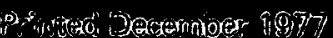




\section{DISCLAIMER}

This report was prepared as an account of work sponsored by an agency of the United States Government. Neither the United States Government nor any agency Thereof, nor any of their employees, makes any warranty, express or implied, or assumes any legal liability or responsibility for the accuracy, completeness, or usefulness of any information, apparatus, product, or process disclosed, or represents that its use would not infringe privately owned rights. Reference herein to any specific commercial product, process, or service by trade name, trademark, manufacturer, or otherwise does not necessarily constitute or imply its endorsement, recommendation, or favoring by the United States Government or any agency thereof. The views and opinions of authors expressed herein do not necessarily state or reflect those of the United States Government or any agency thereof. 


\section{DISCLAIMER}

Portions of this document may be illegible in electronic image products. Images are produced from the best available original document. 
Issued by Sandia Laboratories, operated for the United Sitates Department of Energy by Sandia Corporation.

\section{NOTICE}

This report was prepared as an account of work sponsored by the United States Government. Neither the United State:; nor the United States Department of Energy, nor any of their employees, nor any of their contractors, subcontractors, or their employees, makes any warranty, express or implied, or assumes any legal liability or responsibility for the accuracy, completeness or usefulness of any information, apparatus, product or process disclosed, or represents that its use wciuld not infringe privately owned rights. 
SAND77-0946

Unlimited Release

Printed December 1977 SITE SELECTION AND EVALUATION STUDIES OF THE WASTE ISOLATION
PILOT PLANT (WIPP), LOS MEDAÑOS, EDDY COUNTY, NM

George B. Griswold

Underground Process Control Division 5732

Sandia Laboratories

Albuquerque, NM 87115

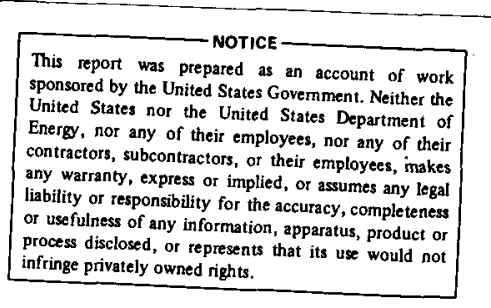

\begin{abstract}
Bedded-salt deposits of the Salado Formation have been selected for evaluation for a proposed Waste Isolation Pilot Plant (WIPP) to be located in Eddy County, NM, $\sim 26$ mi east of Carlsbad. Site selection and evaluation studies that included geologic mapping, geophysical surveys, drilling, and resource appraisal were conducted over and under the prospective location. The lower portion of the Salado meets essential criteria for waste isolation. Beds chosen for waste storage lie 2074-2730 ft below the surface. High-purity salt exists at these depths, and the geologic structure revealed by geophysical surveys indicates that these beds are essentially flat. Additional geophysical surveys are now under way. The initial interpretation of the new data indicates that more structure may exist in the salt beds in the northern portion of the site area. Full evaluation of potentially commercial deposits of potash and natural gas within the WIPP site will be reported by separate studies, as will be the hydrologic details of the region.
\end{abstract}




\section{ACKNOWLEDGMENT}

Site evaluation efforts described in this report include the condensation of the work of many individuals and contracting companies. References acknowledge those who have contributed to the study.

Wendell $\mathrm{D}$. Weart of Department 5310 supported the investigations ard was an effective spokesman to representatives from both ERDA and the State of New Mexico on the progress of site studies. Les R. Hill of Division 5311 and his staff provided technical assistance, arid Robert D. Statler of Division 1133 and his staff effectively supported the field operations. H. Clyde Walker, of Division 5342 , administered a large number of contracts and monitored project cos $\mathrm{s}$. W. Earl Cunningham of Fenix and Scission, Inc. was in direct charge of all drilling operations.

Special mention is due a working panel that periodically reviewed the progress of the site study. Members of this panel were: Roger Y. Anderson, Charles L. Elliot, Gebhard J. Long, Edward L. Reed, Sherman A. White, and Roy C. Williamson, Jr.

Charles L. Jones of the U.S. Geological Survey has been associated with the WIPP since its inception. His works and thoughts provide the basis for parts of this report. Jerry W. Mercer and Brennon R. Orr, also of USGS, conducted the hydrologic studies at Los Meidaños. 


\section{CONTENTS}

Introduction

Location of Los Medaños Study Area and Geographic Definition of the Proposed WIPP Site

History of Site Selection and Evaluation at Los Medaños

Large-Scale Screening Criteria Used to Select the Los Medaños Site

Topography and Surface Features

Surficial Geology

Subsurface Structure From Surface Down to the Top of the Castile

Subsurface Structure From the Precambrian Basement Up to the Castile

Geologic Cross Sections and Composite Structure Map

Horizon Selection for Waste Disposal

Geophysical Surveys

Shallow Seismic Surveys

Deep Seismic Exploration Surveys

Magnetic Surveys

Gravimetric Surveys

Schlumberger Expansion Arrays

Detailed Electrical and Gravity Surveys Conducted Over

Breccia Pipes Outside the Site Area

Mineral Resource Evaluation

Oil and Gas

Potash

Potential Geologic Hazards

Brine and Gas Accumulations in the Salado

Suberosion of Salt at the Base of the Evaporites and Relationship to Breccia Pipes and Geopressured Brine Reservoirs 
TABLES

Table

I Drill Hole Information Available

Page

II Seismic Structure Mapping Horizons

14

III Stratigraphic Summary of Four Holes

17

IV Results of Drill-Stem Testing

20

V Wireline Geophysical Logs Run In ERDA No. 9

22

Horizon Selection, ERDA No. 9

VI

Horizon Selection, AEC No. 8

Brine Flows From Nearby Wells 


\section{ILLUSTRATIONS}

Figure

1

2

3

4

5

5

General Location of Los Medaños and Alternate Sites

Site Selection Criteria Overlay

Topographic and Geologic Map of Los Medaños

Index of Drill Holes

Subcrop Geologic Map of Los Medaños

Geologic Section Looking Northwest

Geologic Section Looking Northeast

Structure Maps - Gatuna to Rustler

Structure Maps - Magenta to Vaca Triste

Isopach Maps - Gatuna to Salado

Isopach Maps - Salado to Base 126 Marker Bed

Structure of Top of Salado Formation

Structure of Base of 124 Marker Bed

Structure of a Horizon in the Middle of the Castile Formation

Structure of the Delaware Sandstone

Structure of the Morrow Limestone

Structure of a Devonian Horizon

Composite of Gravity and Seismic

ERDA No. 9 Schematic Diagram

U.S. Geological Survey Well Record - ERDA No. 9

Borehole Geophysical Logs for ERDA No. 9, 0-1000 ft.

Borehole Geophysical Logs for ERDA No. 9, 1000-2000 ft.

Borehole Geophysical Logs for ERDA No. 9, $2000 \mathrm{ft}$. to TD

Sandia Seismic Profile Lines 1 and 2

Details of Two Anomalies Along Seismic Profile Line 2

Compilation of Seismic Lines

Location of Schlumberger Expansion Arrays

Inclined Air Photos of Breccia Pipes

Electrical Survey Results Over a Breccia Pipe (Hill A \& B)

Electrical Survey Results Over a Shallow Sink Hole in Section 9

Potash Resources

NOTE: Figures accompany this report in a separately wrapped package. They are arranged by numerical sequence in the package. 


\section{ILLUSTRATIONS (Cont.)}

\section{Figure}

32 Hydrocarbon Reservoirs and Possible Extensions

33 General Features

34 Geologic Features

35 Geophysical Surveying

$36 \quad$ Drilling Operations

$37 \quad$ Core Handling Procedures 


\section{SITE SELECTION AND EVALUATION STUDIES OF THE WASTE ISOLATION PILOT PLANT (WIPP), LOS MEDANOS, EDDY COUNTY, NM}

Introduction

Sandia Laboratories has investigated the feasibility of constructing an underground facility for the terminal isolation of radioactive waste (radwaste) in southeastern New Mexico salt beds. The project is known as the Waste Isolation Pilot Plant (WIPP). One objective of the project is to establish the suitability of halite (salt) as the surrounding medium for radwaste. This report addresses the initial site selection and evaluation of an area believed to be suitable.

The scope of this report is limited to geologic investigation of the immediate area proposed for the site. Other studies that relate to site characterization, such as hydrology and ecology, will not be discussed in this report but will be reported separately. Site investigations are continuing, with new knowledge being gained almost daily. This report considers only studies completed before June $1,1977$.

Much previous geologic work preceded Sandia's entrance into the WIPP program. It is assumed that the reader is knowledgeable about published reports of the U.S. Geological Survey (USGS) on their work from 1972-1975. In addition, familiarity with the regional geologic setting of the New Mexico portion of the Delaware Basin is assumed. A regional geologic summary is being prepared by Dennis Powers and Sue-Ellen Shaffer (SAND77-0448).

This report is supported with 37 illustrations (Figures 1-37). The first 18 are maps that commence with the surface and progress downward through the geologic section. They will not necessarily be introduced in that order in the text. Figures 19-27 deal with drilling, geophysics, and resources. The last five illustrations (Figures 33-37) contain photographic scenes of the general area and the activities conducted during site evaluation. A reader not acquainted with the physiography of southeast New. Mexico or not knowledgeable in the techniques of geologic exploration may find it desirable to review these photographs before attempting to digest the text that follows.

Engineering studies have indicated that $\sim 3$ sq $\mathrm{mi}$ will be needed for the underground facilities. Additional area will be required beyond the excavated area to ensure the long-term integrity of the repository. A 1-mi-wide zone around the repository will be established in which no underground excavation or deep drilling is allowed, with an additional 1-mi-wide zone established in which some underground mining and deep drilling will be allowed. On the surface, only the plant site (an area limited to $\sim 60$ acres) will require restricted access. The eventual design led to the designation of four zones: 


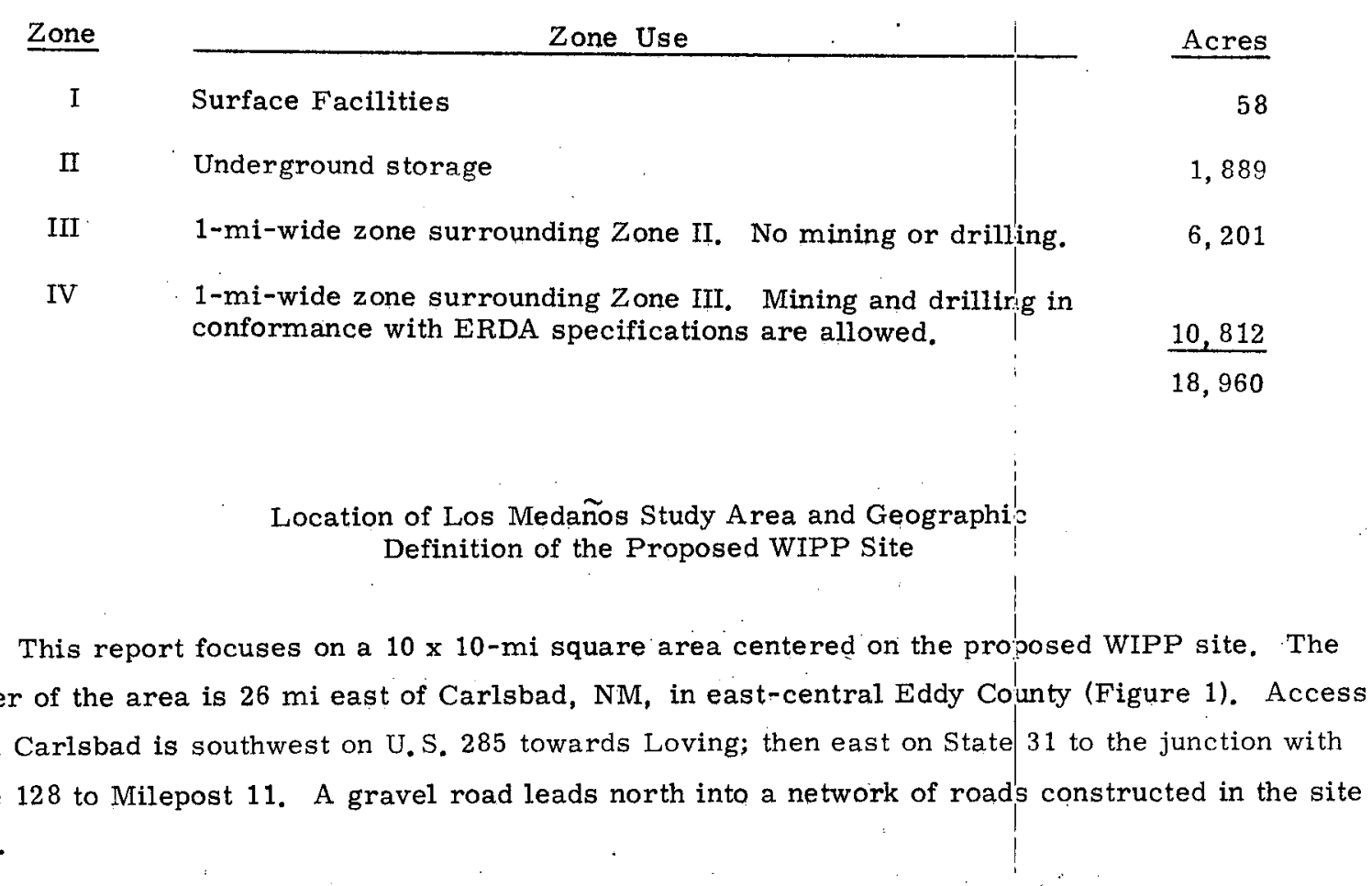

Figure 3 is a topographic map of the Los Medaños study area scaled lat 1 in. $=4000 \mathrm{ft}$, a standard scale used for most of the maps presented. This $10 \times 10-\mathrm{mi}$ area will hereafter be referred to as "Los Medaños," the Spanish word for sand dunes. The name appearis on the U.S. Coast and Geodetic 15-min Nash Draw quadrangle for an active dune field near the Jaimes Ranch in the southern part of the map area.

The WIPP site area, divided by the previously described zones, is also shown in Figure 3 . The irregular pattern of the outer boundary of Zone IV originated from a d'esire to conform to the Bureau of Land Management's (BLM) land subdivision system. The WIPPIprogram plan calls for the entire area within this boundary to be brought under control of the Department of Energy (DOE). The inner boundaries that define Zones II and III are polygonal, designed to minimize the area to be withdrawn and still conform with the requirement to avoid deep drill holes:

In this report, "Los Medaños site" or "area" refers to the $10 \times 10$-ni basic map, whereas the "WIPP site" is the composite of Zones I-IV centered within the larger area.

History of Site Selection and Evaluation at Los Medaî̀os

Oak Ridge National Laboratory (ORNL) and the USGS jointly selected the northern portion of the Delaware Basin as a general location for waste disposal in early 1972.! The USGS immediately began regional geologic investigations resulting in the selection of a 3-sq-ini area at the Lea-Eddy County boundary and designated as the "Old Site" on Figure 1. Field investigations began in March 1974 under the direction of ORNL. Two holes were drilled, AEC No. 7 to $3,918 \mathrm{ft}$ and AEC No. 8 to 
$3,028 \mathrm{ft}$, with the latter hole completed on May 19, 1974 (see Figure 2). The site area then lay dormant until Sandia assumed responsibility for the WIPP program. Drilling activities recommenced in June 1975 with the objective of drilling two more holes, one on each of the remaining site corners. Only the ERDA No. 6 hole, located near the northwest corner, was actually drilled. An artesian flow of brine was encountered at 2,709 ft. This phenomenon, coupled with complex structure as evidenced by the core, resulted in rejection of that site.

The USGS recommended other alternate site areas on November 14, 1975. After further refining site selection criteria, the site now known as Los Medaños, located in T22S, R31E, was selected as the best. Site evaluation activities expanded to include geophysical surveys for mapping geologic structure and drilling to test stratigraphy. ERDA No. 9, a stratigraphic test hole, was drilled in the geographic center of Los Medaños during the summer of 1976. The hole was drilled $2,887 \mathrm{ft}$ just into the top of the Castile Formation. AEC No. 8, originally drilled to $3,028 \mathrm{ft}$, was deepened in 1976 through the Castile and into the Delaware to 4,910 ft. Resource assessment of potash required drilling 21 core holes through the McNutt to intermediate depths. Three hydrologic test locations have been drilled to the top of the Salado. Records from these and other preexisting holes thus provide details of the stratigraphic conditions. Extensive open-hole formation testing was done in ERDA No. 9 and during the deepening of AEC No. 8.

Seismic exploration surveys commenced in the summer of 1976. Twenty-six line miles of 24-fold CDP-type profiling were run along crossing lines through the site. In addition, some 200 line miles of older seismic data were purchased through a brokerage firm from Shell Oil Co. These data were fully reduced and interpreted by August 1976. During the fall and winter of 1976 other seismic profiles were obtained from several oil companies. An updated interpretation using this additional information was completed in early March 1977.

Shallow geophysical survey techniques have also been used at the site. A weight-drop technique was used for high-resolution seismic prospecting in the hope that shallow structures (i.e., those above the Salado) could be mapped. Results were inconclusive. Electrical resistivity surveys were tested in the site area during the summer of 1976. Results have indicated it is not a successful method for detecting regional suberosion of salt from the Rustler and Salado Formations.

Electrical and detailed gravity surveys have been conducted over known breccia pipes near but outside the site. The electrical surveys were successful in detecting the pipes, but the gravity work was only partially successful. This work commenced in the summer of 1976, with data reduction and interpretation completed in early 1977.

Regional gravimetric and airborne magnetic surveys were purchased in mid-1976 from private sources. The magnetic surveys defined more precisely the course of the long dike that passes along the western edge of Nash Draw, and the magnetic profiles were also searched for evidence of other dike trends. The gravity surveys were reviewed for indications of breccia pipes as well as deep structure. Interpretative reports of both surveys were completed by year-end. 
Aerial photos over the site and buffer areas were made on February 19, 1976, before any field activities began, to give a record of the land surface conditions in a pristine condition. A larger area was flown in early October 1976. These photos were used for photogeologic interpretative studies in and around the site.

Oil and gas resources were evaluated by using existing production ani exploratory drilling information, along with structural interpretations obtained from the seismic istudies.

\section{Large-Scale Screening Criteria Used to Select the Los Medianos Site}

The criteria used by ORNL and USGS in selecting the original site along the Lea-Eddy County boundary were:

- A 2-mi radius from any boring through the Ochoan evaporites down into the Delaware, or deeper formations

- Salt of high purity at $<3,000 \mathrm{ft}$

- A minimum depth to suitable salt of $1,000 \mathrm{ft}$

- Avoidance of obvious mineral resources

The cores from AEC Nos. 7 and 8 intercepted commercial grades of potash. At ERDA No. 6, the complex structure and brine flow were sufficient evidence that more selective criteria were needed in selecting future sites.

Selection criteria for the Los Medaños site were expanded to include:

- Avoidance of known oil and gas trends

- Avoidance of the known potash enclave for the site proper, and minimizing the area affected by the buffer zone

- Allowance for a probable salt deformation belt $6 \mathrm{mi}$ wide out into the basin and away from the Capitan Reef

- Establishing a distance of $1 \mathrm{mi}$ or more from suberosion of the top of the Salado Formation

- Minimizing State and private land in Zones I and II

- Avoidance of existing potash lease rights in Zone I and II

- Avoidance of known anticlinal structures

One important criterion was relaxed. The 2-mi radius from deep borings was reduced to $1 \mathrm{mi}$. This change, which resulted from studies performed for ORNL on the dissolutioning effects in boreholes, was made desirable by the extensive deep gas-exploration drilling in the Delaware Basin. Results of borehole plugging and dissolutioning studies indicate that a 1 -mi buffer is very conservative. 
These criteria were applied to all areas in the New. Mexico portion of the Delaware Basin where the Salado was known to be both free of dissolution, at an acceptable mining depth, and free of deep drill holes. Figure 1 illustrates areas that in the judgment of USGS met these three criteria. Figure 2 illustrates how the expanded criteria were applied at Los Medaños. Only the current site and an area designated as Alternate II withstood the test of the additional criteria. The Los Medaños site was preferred because Alternate II was restricted in size, was deeper, and the high-purity salt lying between the Cowden and Castile was thought to be absent. The top of the Salado was at $\sim 800 \mathrm{ft}$ at Los Medaños versus $1500 \mathrm{ft}$ at Alternate II. Other factors favored the selection:

- Structural interpretation of what seismic data was then available to Sandia indicated the Los Medaños site would be in a synclinal area unfavorable for oil and gas accumulation.

- If the site were in a syncline, geopressured brine reservoirs would be less likely.

- Alternate II area lay adjacent to the Double $\mathrm{X}$ and Triple $\mathrm{X}$ shallow oil fields where water flooding for secondary recovery could occur.

No seismic exploration data whatsoever was available to Sandia on the Alternate II area, and only partial coverage at Los Medaños.

Sandia Laboratories selected Los Medaños as the best candidate area in early December 1975.

Topography and Surface Features

The land surface at Los Medaños, an essentially gentle west-to-southwest dipping plane, is devoid of sharp physiographic features. Elevations range from 3,570 ft in the east to $3,250 \mathrm{ft}$ in the west, with the average slope gradient $50 \mathrm{ft} / \mathrm{mi}$. The steepest local gradients are on the leeward side of active sand dunes that reach the angle of repose for such sand. The most prominent topographic feature is Livingston Ridge, a mild escarpment $75 \mathrm{ft}$ high. A small sinkhole $30 \mathrm{ft}$ deep and $\sim 1,000 \mathrm{ft}$ in diameter exists in the north part of the site. Partially stabilized sand dunes cover most of the land surface, particularly to the north, east, and southeast. Active dunes are present in the south. The flattest terrain is on the west where the land surface consists of outcroppings of Mescalero caliche,

\section{Surficial Geology}

Outcroppings in the site area consist of Rustler and Dewey Lake of Permian age, the Gatuna of Pleistocene age (all extensively covered by caliche), and then sand dunes of recent but not accurately dated age. Surficial geology is shown in Figure 3. Because this map was compiled from aerial photos, small outcroppings may have gone undetected. 
Outcroppings conform to the known subsurface geology, which is a nórth-striking and gently east-dipping monocline, with the oldest rocks exposed on the escarpment at Livingston Ridge. The Dewey Lake and Gatuna are present sparingly on the ridge face and immediately pass under the caliche eastward. Scattered outcrops of Rustler lie to the east. The caliche surface has. been breached along a shallow drainage extending across Livingston Ridge in the northwest part of the area. Outcroppings are lost after entering the dune field and seldom reappear eastward in the site area.

\section{Subsurface Structure From Surface Down to the Top of the Castile}

It is desirable to describe the sediments and their structure from the surface to the top of the Castile separately from sediments in deeper beds. The sediments above the Castile represent an interval where standard seismic exploration records do not resolve the units, and drilling provides the only realistic exploration tool. This is true in spite of electrical resistivity surveys capable of giving some insight into the top evaporites; e.g. , base of the Dewey Lake to the first salt or anhydrite, whether in the Rustler or Salado. Near the site described as the arjea shown in Figure 4 , there are 158 drill holes from which information can be gleaned in drilling records. This information is summarized in Table I.

TABLE I

Drill Hole Information Available

\begin{tabular}{|c|c|c|c|}
\hline Type Boring & $\begin{array}{l}\text { Mean Depth } \\
\text { (ft) }\end{array}$ & Complete Record to & Partial Record to \\
\hline 21 Potash Holes (Sandia) & 1,500 & Base of McNutt & \\
\hline 5 ERDA Hydro Holes & 850 & Top of Salado & \\
\hline 102 Potash Holes (Industry) & 1,500 & & $\begin{array}{l}\text { Top Salado, base of } \\
124\end{array}$ \\
\hline $\begin{array}{l}5 \text { Petroleum Development/ } \\
\text { Exploratory }\end{array}$ & $>4,000$ & & $\begin{array}{l}\text { Dewey Lake, Rustler, } \\
\text { Salado, Castile, and } \\
\text { deeper }\end{array}$ \\
\hline $\begin{array}{l}21 \text { Petroleum Development/ } \\
\text { Exploratory }\end{array}$ & $>4,000$ & & $\begin{array}{l}\text { Base of Castile down } \\
\text { to total depth }\end{array}$ \\
\hline AEC No. 7 & 3,918 & Lower part of Castile & \\
\hline AEC No. 8 & 4,910 & Upper part of Delaware & \\
\hline ERDA No. 6 & 2,775 & Cowden Anhydrite & \\
\hline ERDA No. 9 & 2,887 & Top of Castile. & \\
\hline
\end{tabular}


Wireline geophysical logs were run in the 21 potash exploratory holes drilled by Sandia. These logs allowed picking of all significant formation changes down to the depth drilled. For other potash holes drilled by private industry, the procedure was much simpler. These holes were rotarydrilled with no core down into the upper part of the Salado and then cored to depths slightly below the base of the $124 \mathrm{Bed}$. No wireline logs were run. The depth to the 124 Bed is considered to be reliable, but the depth to the top of the Salado had to be inferred from examination of the rotary drill cuttings. Moreover, unless care was taken to use a salt-saturated circulating medium, the cuttings were leached of halite, which resulted in picking the top of the Salado deeper than the actual formation. Therefore, the contours on the base of the $124 \mathrm{Bed}$ are more accurate than those for the top of Salado.

These drill records are interpreted in Figures 5-13. The immediate subcrop geology (i. e., what is present immediately beneath the sand and caliche) is shown in Figure 5. The Santa Rosa Formation covers the east side of the mapped area. Note that the younger Gatuna is absent on top of the Santa Rosa but covers an extensive portion of the west side, where it rests directly on the Dewey Lake. Farther west, the Dewey Lake is exposed in a belt that follows the Livingston Ridge escarpment. The Rustler is exposed in the extreme west on the plain below Livingston Ridge. The setting described conforms to an outcrop pattern expected from nearly flat-lying beds that have been truncated by erosion to conform with existing topography. There is the suggestion that the thin Gatuna Formation (never more than $30 \mathrm{ft}$ thick) represents outwash alluvial deposition as the Santa Rosa was eroded from west to east. A tongue of exposed Dewey Lake that may represent a shallow postcaliche erosional channel extends southeast from Livingston Ridge.

Figures 8 and 9 present smooth structural contouring of eight shallow stratigraphic horizons. These maps cover a smaller area than the standard site-area maps. This smaller area is that in which extensive well logs were obtained from the 21 potash exploration holes. As previously explained, detailed records are not available for the industry-drilled potash and oil/gas holes in the surrounding area.

The top of the Gatuna structure map (Figure 8) is somewhat misleading in that it represents not only that top but the top of the Santa Rosa or Dewey Lake where the Gatuna is absent. The other seven maps are normal structure maps. The form of the top of the Santa Rosa Formation appears to be that of a flat-lying bed that has suffered erosion encroachment from the west. On the other hand, the top of the Dewey Lake has had little erosion and presents itself as a flat-lying, undulating surface. The top of the Rustler Formation is the first horizon to reveal a southeast-plunging synclinal structure. This structure persists in the deeper horizons in this sequence of maps; e. g., the Vaca Triste that marks the top of the McNutt Member of the Salado.

The four maps in Figure 10 and the top two in Figure 11 are isopachous contours for the intervals between the surfaces just described. The erosional wedge shape of the Santa Rosa is quite evident, as is the rapid thinning of the Dewey Lake towards Livingston Ridge and Nash Draw that is also caused by erosion. 
The Rustler rapidly thickens from $300 \mathrm{ft}$ in the center of the area to $500 \mathrm{ft}$ in the extreme southeast due to decreasing suberosion of salt from within this formation A suberosion front is postulated along the steepest gradient of these contours. About $200 \mathrm{ft}$ of salt has been removed over all except the extreme southeast part of the area. 'This suberosion is believed to have preceded the suberosion in the underlying Salado.

The isopach of the interval from the top of the Salado to the base of the 103 Marker Bed (Figure 11, upper left map) reveals that the suberosion wedge extends down to the top of Salado salt in the extreme west. (Note the rapid thinning west of Hole P-12.) Indeed, Holes P-12, -13 , and -14 exhibit solution residue at the top of the Salado, and in Hole P-14 evidence exis is indicating a thin brine aquifer located at the very top of the first salt bed penetrated. The approximate position of these suberosion fronts, Salado and Rustler, is shown in Figure 5. The position is approximate but the best that can be given. The front in the Salado Formation is somewhat farther east than what USGS had postulated (refer to Figure 2).

The lower two maps shown in Figure 11 concern thicknesses related to the 124 Marker Bed. The structure of that horizon will be discussed later. Suffice it to state now that both maps are featureless and reveal only that the intervals gradually thicken southwari.

Figure 12 presents the smoothed contour results for the top of the Salado in the study area. The humped contours on the west reflect the removal of salt by suberosion. The same southeastplunging syncline open to the southeast that was observable in the Rustler Formation is in evidence. A cluster of three depressions lies at the upper (northwest) end of this tivend. The deepest of these is centered on Hole F-91 in the southwest corner of Section 10, T21S, R31E. No detailed record is available on this industry-drilled hole, and it is not known if the overlyirig Rustler, Dewey Lake, and Santa Rosa Formations are actually depressed as one would suspect, or if the top of the Salado was erroneously reported. The low is near a shallow surface sink located ir the extreme southeast part of Section 9 .

Anticlinal structures are shown over ERDA No. 6 in the extreme riortheast and Hole B-1, a deep gas well properly known as Belco Hudson Federal No. 1 and located to the southwest in Section 1, T23S, R30E. Both structures are known to possess geopressured brine reservoirs in the underlying Castile Formation.

Structural contours for the base of the 124 Marker Bed are given in Figure 13. The 124 Marker Bed is the deepest and most consistently reported bed cored in all of the potash drill holes. In addition, the depths reported in the industry-drilled holes are considered valid because they are based on cored sections.

The surface of the base of the 124 Marker Bed is similar to that described for the top of the Salado. The two anticlines centered on ERDA No. 6 and the Belco Hudson Federal No. 1 well persist. Note the centers of two depressions along the axis of the syncline? The one to the extreme 
east may not be closed since drill records are sparse in that area. The other roughly coincides with the cluster of three lows described for the top of the Salado. The center has shifted slightly to the west, centered on Hole F-92.

In Zones I and II the surface of the 124 Marker Bed is relatively uniform, with a gentle eastward dip that varies from $80-100 \mathrm{ft} / \mathrm{mi}$. This horizon is 470 and $1,020 \mathrm{ft}$, respectively, above the low-level transuranic (TRU) and intermediate-level (RH) mining horizons selected for waste disposal in the WIPP facility; therefore, it is the best estimate of structural conditions in those levels. No faulting is discernible from the drilling information. High-resolution geophysical surveys to be conducted over the site area are expected to confirm that significant faults do not exist.

Subsurface Structure from the Precambrian Basement Up to the Castile

Deep drilling at Los Medaños is limited to the cluster of five holes in the James Ranch gas field and to 21 other tests in a widely spaced pattern. The spacing is such that only regional deep structural trends can be projected. Seismic exploration surveys, consisting of 26 line miles of new data obtained by Sandia plus $\sim 500$ line miles of proprietary data from industry, were used to refine the structural setting. Results are shown in Figures 14-17, which are for the surfaces indicated in Table II.

\section{TABLE II}

Seismic Structure Mapping Horizons

\begin{tabular}{|c|c|c|c|}
\hline Bed & Stratigraphic Position & $\begin{array}{l}\text { Mean Depth } \\
\text { (ft) } \\
\end{array}$ & $\begin{array}{c}\text { Mean Elevation } \\
(\mathrm{ft})\end{array}$ \\
\hline Castile Horizon & $\begin{array}{l}\text { 700 ft above Base. } \\
\text { Ochoan Age }\end{array}$ & 3,400 & Sea Level \\
\hline Delaware Sandstone & $\begin{array}{l}\text { Top of Delaware Mountain } \\
\text { Group. Guadalupian Age }\end{array}$ & 4,200 & -800 \\
\hline Morrow Limestone & $\begin{array}{l}\text { Principal gas-producing } \\
\text { horizon at Los Medaños. } \\
\text { Lower Pennsylvanian Age }\end{array}$ & 13,400 & $-10,000$ \\
\hline Devonian Marker & Limestone Unit & 15,900 & $-12,500$ \\
\hline
\end{tabular}

Two seismic profiles are exhibited in Figure 24 to illustrate the quality of the data obtained by the Sandia surveys. On these profiles the position of the beds listed in Table II is superimposed to illustrate the interpretation technique. The approximate Precambrian surface is indicated. Even though some consistent horizons in the Precambrian appear on the records, they are not interpretable, and no attempt has been made to do any quantitative structural interpretation below the. Devonian marker. 
The seismic interpretation agrees with the regional structural setting. These data illustrate that on a small scale warping and faults exist, these structures becoming more pronounced with depth. Seismic interpretation is largely an art form even though the field surveys use sophisticated electronics, and the raw data is digitally processed with elaborate programs to condition and then "stack" the seismic response signals. No two geophysicists fully agree; this is particularly true in analyzing fault traces. The interpretation presented here is the more complex of two studies performed by independent geophysicists. From the standpoint of defending the geologic stability of the repository, it is more conse rvative to use the complex interpretation. The structure will be described from the deepest (Devonian) back up to the Castile.

Referring to Figure 17, the fault trends are north to northeast with a subsidiary trend to the northwest. The maximum fault displacement seen on the Devonian is $300 \mathrm{ft}$, and the most common mode is a downdropping on the west side. Anticlines and synclines having amplitudes of $500 \mathrm{ft}$ from the troughs to ridges are prevalent in the Devonian. Coming up to the Morrow Limestone, some $2,500 \mathrm{ft}$ higher stratigraphically, the structure is less complex (Figure 16). The strong north-to-northeast trending faults have died away. Structural relief from syncline to anticline is reduced to a 200-500 ft range. At the Delaware sandstone horizon, about $10,000 \mathrm{ft}$ above the Morrow Limestone, warping reduces to $300 \mathrm{ft}$ maximum (Figure 15). The faults shown are not continuous extensions of faults shown in the Morrow to Devonian but represerit two periods of faulting. The older terminates in the Pennsylvanian and is related to basement-type movements, and a younger post-Permian set formed due to compaction during diagenesis after deposition of the Delaware Mountain and perhaps the Ochoan evaporites.

The Castile horizon, shown in Figure 14, is the shallowest structure map that can be gleaned from existing seismic surveys. The mapping horizon is the middle, not the top, of the Castile Formation. This horizon lies $850-1300 \mathrm{ft}$, respectively, below the low-level transuranic (TRU) and intermediate-level remote-handled $(\mathrm{RH})$ mining horizons for the WIPP prijject. It is, therefore, the best representation of structural conditions immediately below the planned repository mining levels just as the base of the 124 Marker Bed was for the conditions above.

Possible faults are shown. Minor faulting with displacements of less than $10 \mathrm{ft}$ has been witnessed in the potash mines. Faults shown in the Castile should be corisidered tentative pending more-detailed and higher-resolution seismic profiling. The northeast-triending fault may be partially substantiated by surface outcroppings (refer to Figure 3). The fault trace follows the approximate trend of Livingston Ridge. The Dewey Lake Formation outcrops along the west face of the ridge, and the local dips are $10-20^{\circ}$ to the west. This steep local attitude, which is reverse to the regional dip, is attributed to slumpage due to salt dissolutioning at the top of the Salado in Nash Draw. However, the Rustler Formation outcrops immediately to thie west in Section 15, T22S, R30E. The thickness of the Dewey Lake is thought to be $250 \mathrm{ft}$ or more, whereas the topographic relief is only $100 \mathrm{ft}$. Hence, a fault may exist between the Rustler outcrops and the ridge face. Such a fault would coincide with the trend and displacement mode of the one shown on the Castile surface. The vertical displacement could be as great as $150 \mathrm{ft}$ with the clownthrown block on the 
east. No fault trace is observable on the air photos, and the veneer of caliche that caps Livingston Ridge is not disturbed. If the speculated fault exists, then its last period of movement preceded the formation of the caliche. Another possibility is that the Rustler and upper part of the Salado may rapidly thicken as they pass westward out from under Livingston Ridge; a thickening that can be attributed to swelling of anhydrite being converted to gypsum.

The structure of the Castile horizon is in general agreement with that exhibited by the 124 Marker Bed. The anticlines around the Belco Hudson Federal No. 1 well in Section 1, T23S, R30E at both horizons are congruent. An anticline is expected under the ERDA No. 6 location in the Castile; however, the seismic data available to use was not of sufficient quality to allow valid interpretation in that particular area. The main difference in the shapes of the 124 Marker Bed and Castile horizon surfaces is that the southeast-plunging syncline on the former has been subdued on the latter. Indeed, a closed anticline is postulated in the Castile centered in the northeast corner of Section 21, T22S, R31E. The low northwest of this anticline is roughly in the same position as the sharp low revealed in the 124 Marker Bed.

\section{Geologic Cross Sections and Composite Structure Map}

The results of the previously described geologic structure maps were used to compile two geologic cross sections along crossing lines through the site area. Figure 6 is a cross section looking northwest, and Figure 7 is a cross section looking northeast. The vertical scale is exaggerated three and one-third over the horizontal; hence, the structure is amplified. Key potash exploration and oil/gas wells that were used to assist compilation of the cross sections are shown. Interpolation between holes made use of the plan structure maps.

A composite plan map of structural trends is presented as Figure 18. This map attempts to correlate known structural trends in the "shallow" and "deep," defined as the Delaware and Devonian, respectively. These trends were established by a synthesis of the seismic and gravity data available. This particular map was more useful in estimating hydrocarbon potential of the site area than in revealing features in the Ochoan evaporites.

Stratigraphic Test Drilling at Los Medaños

The reader may find it helpful to review the pictorial displays in Figures 36 and 37 to understand the text that immediately follows.

Four deep core holes have been drilled for stratigraphic and physical testing of salt beds believed to be suitable for waste disposal. Essential stratigraphic data are summarized in Table III. 
TABLE III

Stratigraphic Summary of Four Holes

Drill Hole Number

\begin{tabular}{|c|c|c|c|c|c|c|c|c|}
\hline & & & & & & & & \\
\hline Location (section/twp/range) & $20 / 22$ & $S / 31 E$ & $35 / 21$ & $\mathrm{~S} / 31 \mathrm{E}$ & $11 / 2 ?$ & $S / 31 E$ & $31 / 21$ & $S / 32 E$ \\
\hline Date Completed & $6 / 2$ & $6 / 76$ & $9 / 2$ & $4 / 75$ & $8 / 5$ & $/ 76^{*}$ & $4 / 18$ & $8 / 74$ \\
\hline Surface (Kelly Bushing) & & $415)$ & & 536 & & 542) & $(36$ & 662) \\
\hline Formation Tops & Depth & Elev. & Depth & Elev. & Dept? & Elev. & Depth & Elev. \\
\hline Gatuna & 27 & 3,388 & 12 & 3,524 & & --- & $-\cdots-$ & --- \\
\hline Santa Rosa & 54 & 3,361 & 22 & 3,514 & 25 & 3,516 & 20 & 3,642 \\
\hline Dewey Lake & 63 & 3,352 & 71 & 3,465 & $17: 1$ & 3,368 & 120 & 3,542 \\
\hline Rustler & 550 & 2,865 & 536 & 3,000 & 669 & 2,873 & 669 & 2,993 \\
\hline Magenta & 610 & 2,805 & 595 & 2,941 & 725 & 2,817 & 732 & 2,930 \\
\hline Culebra & 720 & 2,695 & 710 & 2,826 & 843 & 2,699 & 876 & 2,786 \\
\hline Salado & 860 & 2,555 & 815 & 2,721 & 994 & 2,548 & 998 & 2,664 \\
\hline 103 Marker (base) & 1,050 & 2,365 & 984 & 2,552 & 1,170 & 2,372 & 1,177 & 2,485 \\
\hline Vaca Triste (base) & 1,370 & 2,045 & 1,282 & 2,254 & $1,47,6$ & 2,066 & 1,510 & 2,152 \\
\hline 124 Marker (base) & 1,670 & 1,745 & 1,537 & 1,999 & $1,74 i$ & 1,801 & 1,788 & 1,874 \\
\hline 126 Marker (base) & 1,744 & 1,671 & 1,613 & 1,923 & 1,822 & 1,720 & 1,874 & 1,788 \\
\hline 136 Marker (base) & 2,058 & 1,357 & 1,913 & 1,623 & 2,128 & 1,414 & 2,163 & 1,499 \\
\hline 139 Marker (base) & 2,180 & 1,235 & 2,024 & 1,512 & 2,248 & 1,294 & 2,262 & 1,400 \\
\hline Cowden (top) & 2,540 & 875 & 2,270 & 1,266 & 2,540 & 1,002 & $2,51 \dot{6}$ & 1,146 \\
\hline Cowden (bottom) & 2,562 & 853 & 2,290 & 1,246 & 2,563 & 979 & 2,532 & 1,130 \\
\hline Castile & 2,836 & 579 & 2,555 & 981 & 2,982 & 560 & 2,894 & 768 \\
\hline Delaware & $-\cdots--$ & $-\cdots$ & ---- & $-\cdots$ & 4,315 & -773 & ----- & $-\cdots$ \\
\hline Total Depth & 2,887 & 528 & 2,775 & 761 & 4,910 & $-1,368$ & 3,918 & -256 \\
\hline
\end{tabular}

* AEC No. 8 was drilled to $3028 \mathrm{ft}$ on $5 / 19 / 74$. The hole was reentered and deepened to $4910 \mathrm{ft}$ during July and early August 1976.

Of the four holes, three (ERDA No, 6 and AEC Nos, 7 and 8) were drilled at the old site on the Lee-Eddy County Line. ERDA No. 9 was drilled in the exact center of the Los Medaños site and is of greatest significance to this discussion; however, there was generally excellent lateral correlation between all four holes. The deeper part of ERDA No. 6 is the single exception, where complex structure was revealed by the steep dips in the core along with brine flow encountered immediately below the Cowden. That good lateral correlation exists between holes spaced several miles apart is the traditional experience in the Ochoan evaporites of the Delaware Basin. 
Figure 19 is a diagrammatic section of drilling results from ERDA No. 9. The drilling schedule was as follows:

1. Cement 16-in. surface casing to $40 \mathrm{ft}$ in $20-\mathrm{in}$. hole.

2. Rotary drill into top of Salado (1049 ft).

3. Run wire line geophysical logs.

4. Set 10-3/4-in. casing and cement to $1056 \mathrm{ft}$ in a 15-in. hole. Run bond logs.

5. Convert to an inverted oil-emulsion drilling fluid.

6. Pass circulating system through gas separator (continuous mud analysis and gas sampling).

7. Drill continuous core to depth of $2,887 \mathrm{ft}$ : hole $7-3 / 4 \mathrm{in}$.; core $4-1 / 4 \mathrm{in}$.

8. Conduct three drill-stem tests at selected intervals while drilling.

9. Ream hole to $9-7 / 8$ in. to $2886 \mathrm{ft}$.

10. Run wireline geophysical logs.

11. Conduct six additional tests by straddle-packer testing after logging.

12. Stand 7-in. casing. Cement back to $2540 \mathrm{ft}$. Run bond logs.

13. Run directional survey.

14. Cap well.

The purpose of the extensive formation testing and drilling-fluid monitoring was to detect any evidence of geopressured brine flow such as that found at the ERDA No. 6 hole. No unusual conditions were observed. Table IV summarizes the results of the drill-stem testing. The slight pressure buildups reflect nitrogen-brine accumulations similar to those that are frequently observed in nearby potash mines. These are to be expected throughout the Salado Formation, particularly in or near clay seams. A trace of $\mathrm{H}_{2} \mathrm{~S}$ was detected by the drilling fluid monitors at $1409 \mathrm{ft}$. The concentration was $0.5 \mathrm{ppm}$, well below the limit of hazard to health. Drill-stem Test No. 1 tested this zone, with no further recorded evidence of $\mathrm{H}_{2} \mathrm{~S}$. Trace amounts of $\mathrm{H}_{2} \mathrm{~S}$ may be present in the evaporites, but that $\mathrm{H}_{2} \mathrm{~S}$ was detected at all in this hole testifies more to the sophistication of the gas monitors rather than to an anomalous geologic condition. 
TABLE IV

Results of Drill-Stem Testing

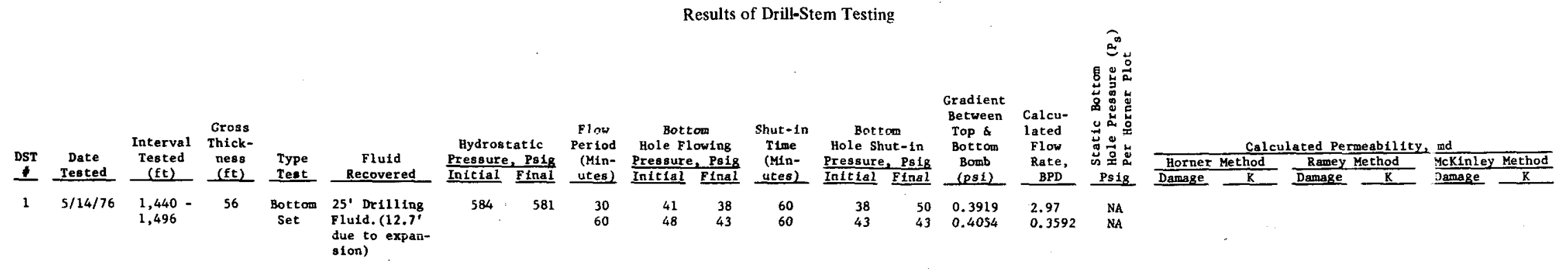

Remarks: Open tool with fair blow. Reopened tool with no blow. No measurable flow. No analysis possible due to short shut-in period \& continuance of afterflow durin period. During drilling, this interval had minor $\mathrm{H}_{2} \mathrm{~S}$ entry recorded.

Remarks: Reportedly potential zone of "torage. No flutd or gas entry observed during drilling. Opened tool with very weak blow. Dead in 13 ". Reopened tool for 2 nd $a 3$ 3rd flows and dead. All fluid entry on DST accounted for by drilling fluid ex * Average permeability per core analys is 2,037 to $2,055.3^{\prime}$ ranged from 0.0003 to $0.17 \mathrm{md}$ with an average $0.019624 \mathrm{md}$.

$3 \quad 5 / 24 / 76$

No fluld or gas entry noted during dr111ing. Interval tested as major clean salt section and to test bottom of hole (total depth). Tool opened with very wr is blow. Dead in

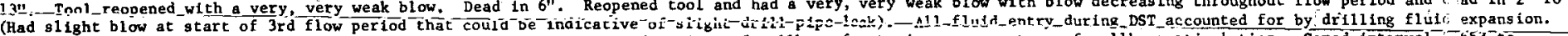
Ramey method of estimating permeability subject to question due to indications of wellbore fracturing or some type of wellibore stimulation. Cored interval .553 to 2,684.7, had permeabilty to air rang ing from 0.0004 to 16.0 md with an average of 1 . Smechanical torque. porosity throughout cored interval is extremely 10.6 at less High perme.
than $0.7 \%$.

Footnotes: Pressure readings normally taken from bottom gauge unless gauge was inoperative.

Attempts to meter surface flow rates with Halliburton and cone \& Kerley low pressure diaphran flow meters

- Based on Halliburton Report by Mr. James E. S1gman dated August 9, 1976 


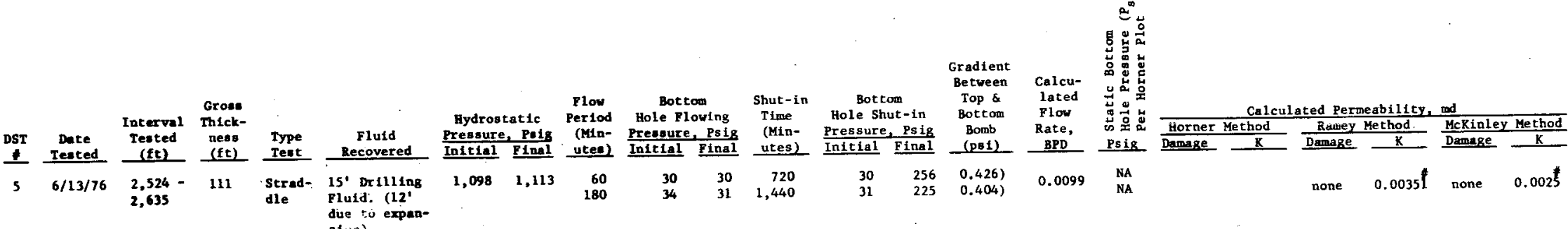

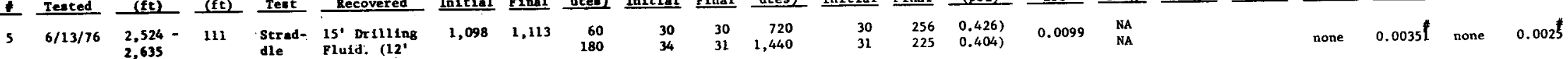
due tor)

with a very wak blow and dead at end of 1 st flow. Reopened with a slight blow and dead in 4 minutes.

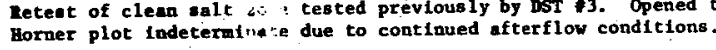

$66 / 15 / 76$

2,310
$2,376-$

66 Strad-

Merun.

Renirka: hisrun - could not obtaln packer seat at either interval.

$76 / 16 / 76 \quad 2,310-36 \quad$ strad-

lenarks: Misun - packer held for flrst flow but lost packer seat then tool opened for second flow.

$8 \quad 6 / 17 / 76$

2,635

90 strad- 3' Drilling

pousible
due to expan-
o Lon)

$\begin{array}{rrrrrr}1,140 & 1,120 & 60 & 29 & 25 & 720 \\ & & 60 & 34 & 28 & 1,080 \\ & 120 & 37 & 29 & 1,440\end{array}$

$\begin{array}{lll}26 & 166 & 0.429) \\ 28 & 151 & 0.400) \\ 29 & 148 & 0.371)\end{array}$

0.0396

$\begin{array}{rlr}272 & \text { none } & 0.00007 \\ \text { NA } & & \end{array}$

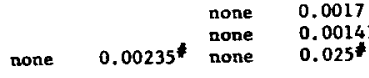

(anker Interval Interval tested is 100 foot clean salt section and possible storage site. Hion on second and third flow. Horner plot indicates possible pressure depletion.

$96 / 20 / 76 \quad 2,310-38 \quad$ stried-

Renerks: Mistun - atteapt to reteat Interval attempted by DST 7 . Packers would not hold. Move tool to $1,455-1,498^{\prime}$.

10
$6 / 20 / 7$
$1,455-$
43 Strad- ${ }_{\text {Fluid }}^{120^{\prime} \text { Drilliag }} 1,001$
667
$\begin{array}{rrrr}60 & 92 & 91 & 720 \\ 60 & 99 & 92 & 1,080 \\ 120 & 98 & 91 & 1,440\end{array}$
$\begin{array}{lll}91 & 199 & 0.36 \\ 92 & 160 & 0.36 \\ 91 & 140 & -\end{array}$
Footnotes: Pressure readings normally taken from bottom gauge unless gauge was inoperative.
Aetempta to neter surface flow rates uith Halliburton and cone a kerley low pressure diaphran flou meters
were unsuccessful. Flow ratea vere too small to measure in all cases.
- Based on Helltburton Report by tr. James E. Sigmon dated AugusL 9, 1976.

$\begin{array}{ll}\text { NA } & \text { NA } \\ \text { NA } & \text { NA } \\ \text { NA } & \text { NA }\end{array}$

none $0.000655^{*}$ none $0.000694^{*}$

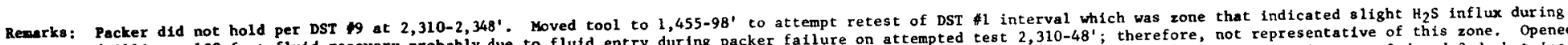
drilling. 120 feet fluld recovery probably due to flutd entry dur ing packer fallure on attempted test $2,310-488^{\prime}$; therefore, not representative of this zone. Opened

tool with very weak blow. Dead in 3 minutes. No blow on 2 ad and 3 rd flow. Horner plots reflect possible depletion from 255 to 175 psise 
The nitrogen-brine accumulations should be at pressures either equal to or greater than the equivalent pressure of a saturated brine column extending from the depth of measurement to the top of the salt beds. The reason is that the brine is completely salt-saturated; if minor amounts of interstitial water are present in the salt, they should reflect a normal salt-brine hydrostatic gradient. On the other hand, if the brine-gas is contained within small confined lenses, then pressures should be equivalent to normal gravity loading of the overlying salt and other rocks. Plastic flowage of the salt should ensure this condition if the brine gases are isolated pockets.

The highest pressure buildup was in Test No. 4 where the test interval was $2635-2886 \mathrm{ft}$. If the fluids were confined by an equivalent brine column, then the pressure would be in the order of $800 \mathrm{psi}$. Since the final shut-in pressure was only 312 psi after $24 \mathrm{hr}$, we must conclude that the drill-stem test did not adequately test the formation. This is not an operational fault of the technique we used, but rather an indication that extremely long shut-in times (perhaps a month or more) will be required. Such times are not realistic for conducting active drilling operations. Therefore, the only conclusion that can be drawn from the 10 drill-stem tests is that no significant amount of fluid is present in the Salado. Definitive tests as to what trace amounts are present and under what presisures must be determined by other means, preferably by perforatioris through a well cased hole.

The core-handling procedures were routine in that as each run was removed, it was cleaned, marked as to footage, examined megascopically for geologic detail, photiographed, and then wrapped and sealed in polyethylene plastic. This suite of core was and continues to be tested for physical and chemical properties. The test results will be reported by others.

Cutting samples were collected routinely every $10 \mathrm{ft}$ during core-section drilling. These samples were examined chemically and by $X$-ray diffraction to determine the quality of the salt and to detect any mineral assemblage extraneous to that expected for the Salido. These analyses are complete, and no anomalous minerals were identified.

A detailed descriptive log of the lithology of ERDA No: 9 is given in Figure 20. The log was compiled from examination of rotary cuttings collected every $10 \mathrm{ft}$ from the surface to $1090 \mathrm{ft}$, and from core examination from there down to the total depth of $2886 \mathrm{ft}$. Coje recovery was excellent, exceeding 95 percent. The $\log$ has indicated that the stratigraphy is quite normal for the Salado Formation in this part of the Delaware Basin. Bedding planes were flat, never exceeding a $5^{\circ}$ dip. While minor amounts of potassium ore minerals occurred in several of the traditional ore-bed horizons, none of the intercepts could be considered as economic.

\section{Horizon Selection for Waste Disposal}

The USGS advised that the two best potential zones for waste disposal were the infra-Cowden halite (i. e., salt beds beneath the Cowden anhydrite and the top of the Ca.stile) and a second zone lying between the 134 and 140 Marker Beds. These selections were based on USGS knowledge gained 
from drilling records and logs from holes drilled throughout the Delaware Basin, and on examination of the core from the three holes drilled at the old site location. A complex suite of wire line geophysical logs was run under open-hole, fluid-filled conditions at ERDA No. 9 to increase the understanding of the entire Salado section, and to verify and refine horizon selection. The following logs were run (Table V):

TABLE V

Wireline Geophysical Logs Run In ERDA No. 9

Type

Acoustic

Acoustic, VDL

Density

Neutron

Spectral gamma

Temperature

Caliper

Induction

Microlaterolog

Neutron lifetime

Cyclic activation

Inelastic neutron

Silicon-calcium )

"Sonan"

Diplog

Fluid density

Sidewall acoustic

Sidewall VDL

"Seisviewer"

Uphole seismic
Purpose

Elastic velocity, $P$ wave

Elastic velocity, $S$ wave

Formation density

Hydrogen detection

Uranium, thorium, potassium

Formation temperature

Hole size

Formation resistivity

Formation resistivity

Calcium, oxygen, silicon, hydrogen

Fluid entry

Dip of bedding planes

Drilling mud density

Elastic velocity, $P$ wave

Elastic velocity, $S$ wave

Hole damage, fractures

Formation velocities

Rarely has such a comprehensive set of borehole geophysical measurements been made in a single hole. To some extent the measurements were redundant, but measuring the same parameters by different sensors has enhanced the credibility of the interpretations.

Figures 21-23 illustrate the wireline geophysical logs for six parameters: density, gamma radiation, caliper, sonic velocity, electrical resistivity, and two neutron activation logs. The combination of natural gamma and sonic velocity was the most useful in picking the traditional marker beds. Normally these beds have polyhalite and anhydrite mixtures that reveal themselves as increases in both natural radiation and seismic velocity. The neutron activation logs consistently 
confirmed our interpretations. The Cowden anhydrite bed and. the Castile are best shown by the density, velocity, and neutron activation logs. Little natural gamma radiation is present in these anhydrites.

A detailed study of each of the various logs was made. In that the objective of the WIPP program is to demonstrate the utility of salt as a medium for waste isolation, then the horizons selected should be those of the highest purity and with fewest nonhalite interbeds. Any zone exceeding $50 \mathrm{ft}$ thick that indicated uniform salt was considered to be a candidate horizon. The logs were then cross-correlated to determine which horizons were the most consistent; $i$, e., absent of anomalous response. It was in this manner that the two mining levels were selected.

The logs confirmed that the purer and thicker halite beds were in the lower portion of the Salado. The Upper Member is clay-and anhydrite-bearing. The McNuti (Middle Member) contains appropriate polyhalite and other hydrous minerals. Within the Lower Member, the infra-Cowden halite was by far the purest and most uniform, as inferred from elastic properties, density, lack of gamma activity, and uniform electrical resistivity. Next in quality was a halite zone between the 136 and 140 Marker Beds. Further refinement led to selection of an intermediate-level TRU (remotehandled) zone within the infra-Cowden and low-level TRU (contact-handled) waste zones (Table VI):

\author{
TABLE VI \\ Horizon Selection, ERDA No. 9
}

\begin{tabular}{|c|c|c|c|c|}
\hline & $\begin{array}{l}\text { Depth } \\
\text { (ft) }\end{array}$ & $\begin{array}{c}\text { Elev. } \\
(\mathrm{ft})\end{array}$ & $\begin{array}{l}\text { Thickness } \\
\text { (ft) }\end{array}$ & $\begin{array}{l}\text { Stratigraphic } \\
\quad \text { Position }\end{array}$ \\
\hline \multicolumn{5}{|c|}{ Contact Waste Zone: } \\
\hline top & 2,074 & $1,352\}$ & 102 & Base of $137 \mathrm{Bed}$ \\
\hline base & 2,176 & $1,250)$ & & Top of 139 Bed \\
\hline
\end{tabular}

Remote-Handled Waste Zone:

$\begin{array}{lll}\text { top } & 2,620 & \begin{array}{c}806 \\ 696\end{array} \\ \text { base } & 2,730 & 696\end{array} \quad \begin{aligned} & \text { Below anhydrite lense } \\ & \text { Above anhydrite lense }\end{aligned}$

Tentative mining plans call for excavation of rooms $\sim 20 \mathrm{ft}$ high; th'ese thicknesses are more than adequate. Ideally, mine openings should be placed in the middle of the zones selected so as to give uniform conditions above and below the repository levels.

A similar suite of logs was run in AEC No. 8 (Table VII) once that hole was deepened into the Delaware. The caliper log indicated some hole enlargement in the salt sections; hence, the logs were not considered as reliable as those from ERDA No. 9. However, they offered a good comparison of conditions $4 \mathrm{mi}$ away. The same horizons appear to be the best for waste disposal and differ only in thickness. 
TABLE VII

Horizon Selection, AEC No. 8

\begin{tabular}{|c|c|c|c|c|}
\hline & $\begin{array}{c}\text { Depth } \\
\text { (ft) } \\
\end{array}$ & $\begin{array}{c}\text { Elevation } \\
(\mathrm{ft})\end{array}$ & $\begin{array}{c}\text { Thickness } \\
\text { (ft) } \\
\end{array}$ & $\begin{array}{c}\text { Stratigraphic } \\
\text { Position }\end{array}$ \\
\hline \multicolumn{5}{|c|}{ Contact Waste Zone: } \\
\hline top & 2,128 & $1,414\}$ & \multirow{2}{*}{118} & Base of 136 \\
\hline base & 2,246 & $1,296)$ & & Top of 139 \\
\hline \multicolumn{5}{|c|}{ Remote-Handled Waste Zone: } \\
\hline top & 2,616 & $926)$ & \multirow{2}{*}{104} & Below anhydrite lense \\
\hline base & 2,720 & $822)$ & & Above anhydrite lense \\
\hline
\end{tabular}

A summary of significant physical properties for the proposed horizons to be used is given in Table VIII. The elastic data presented are based on the constitutive equations where, if density, P-wave, and S-wave velocities are known, then all elastic properties can be calculated. The table illustrates that the halite horizons are quite uniform.

\section{Geophysical Surveys}

The seismic surveys have been partially described in the section dealing with the structure beneath the Salado Formation. However, a fuller description of both those surveys and other geophysical exploration surveys needs to be presented to demonstrate how remote sensing from the surface has assisted in site evaluation. Both shallow and deep seismic surveys have been conducted that rely on two properties of the rock layers, P-wave velocity and density. Electrical surveys have also been conducted that measure earth resistivity. Finally, magnetics and gravimetric surveys that are potentiometric measurements of the total earth fields were used.

\section{Shallow Seismic Surveys}

A rectangular grid of 1/2-mi survey lines was run at Los Medaños. A totaì of 43 line miles were surveyed. The system utilized close-spaced clusters of geophones implanted into the soil. Seismic energy was imparted into the earth by hoisting and then dropping a 1,000-1b weight under freefall. Signals were recorded and timed in relation to the moment of impact of the weight onto the land surface. Wave trains reflected from deep horizons were observed and, by using known velocities for the immediately underlying sedimentary beds, the depths to significant acoustic impedance interfaces were calculated.

The results of this survey are ambiguous because high frequencies are necessary to resolve shallow bodies, and the weight-dropping technique failed to provide sufficient amplitude of highfrequency signals. The results of the shallow work have been discarded because many anomalies thought to exist, based on that survey, were disproven after the 21 potash core holes were drilled. If future shallow seismic surveys are conducted, considerably more sophistication will be required of the instrumentation system along with stronger energy input. 
TABLE VIII

Physical Properties of Disposal Horizons

TRU Leve1

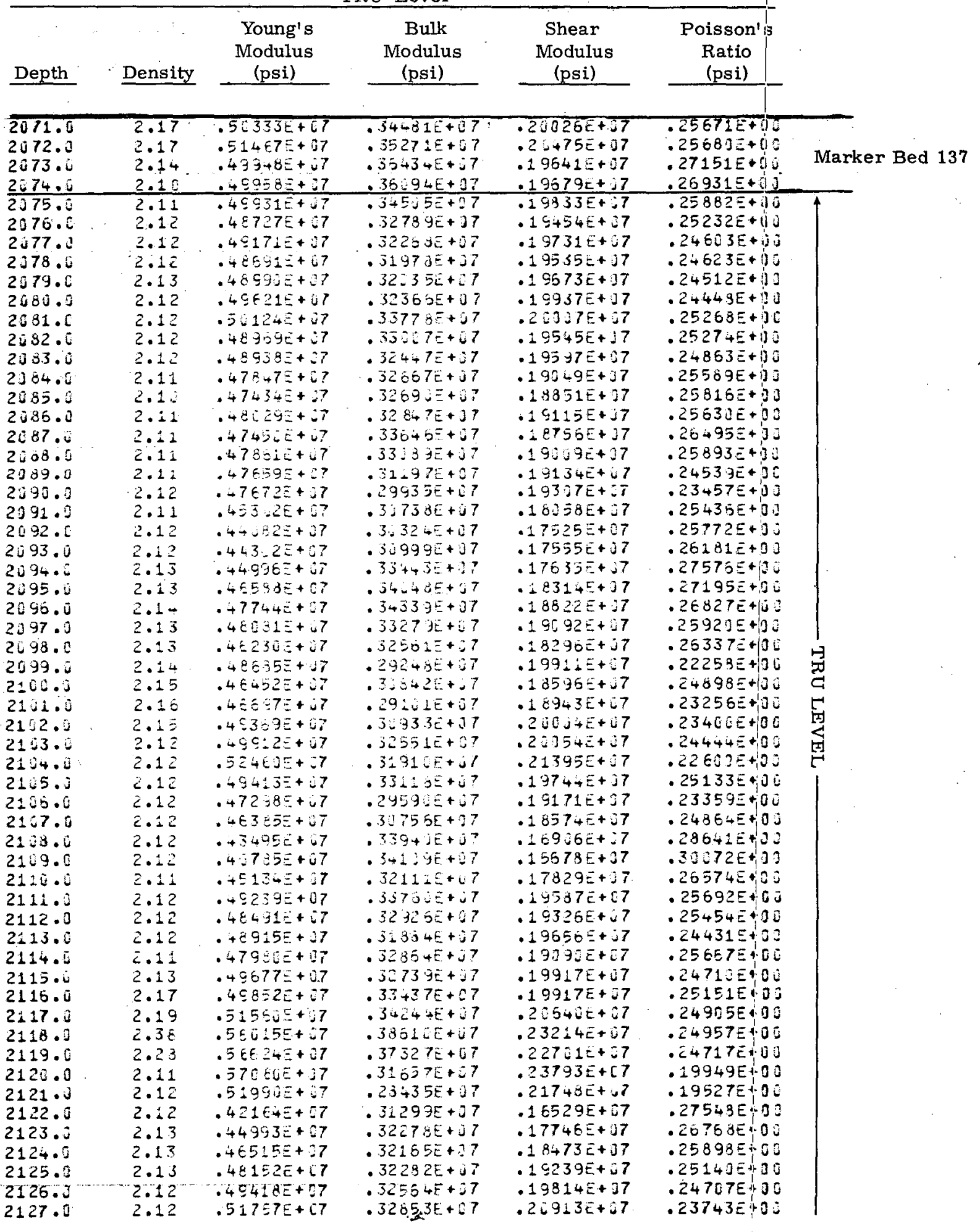


TABLE VII (cont'd)

Physical Properties of Disposal Horizons

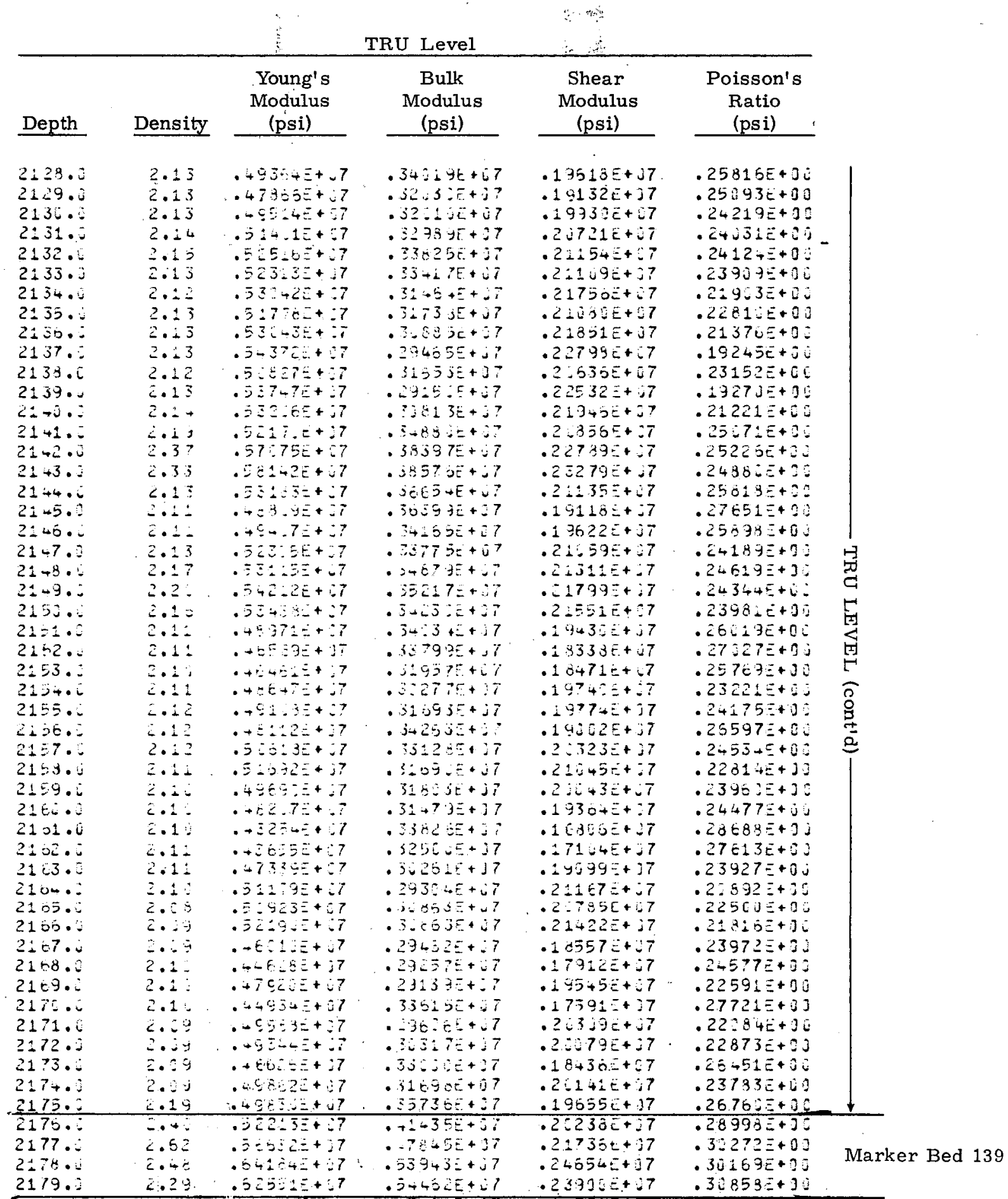


TABLE VIII (cont'd)

Physical Properties of Disposal Horizons

RH Leve1

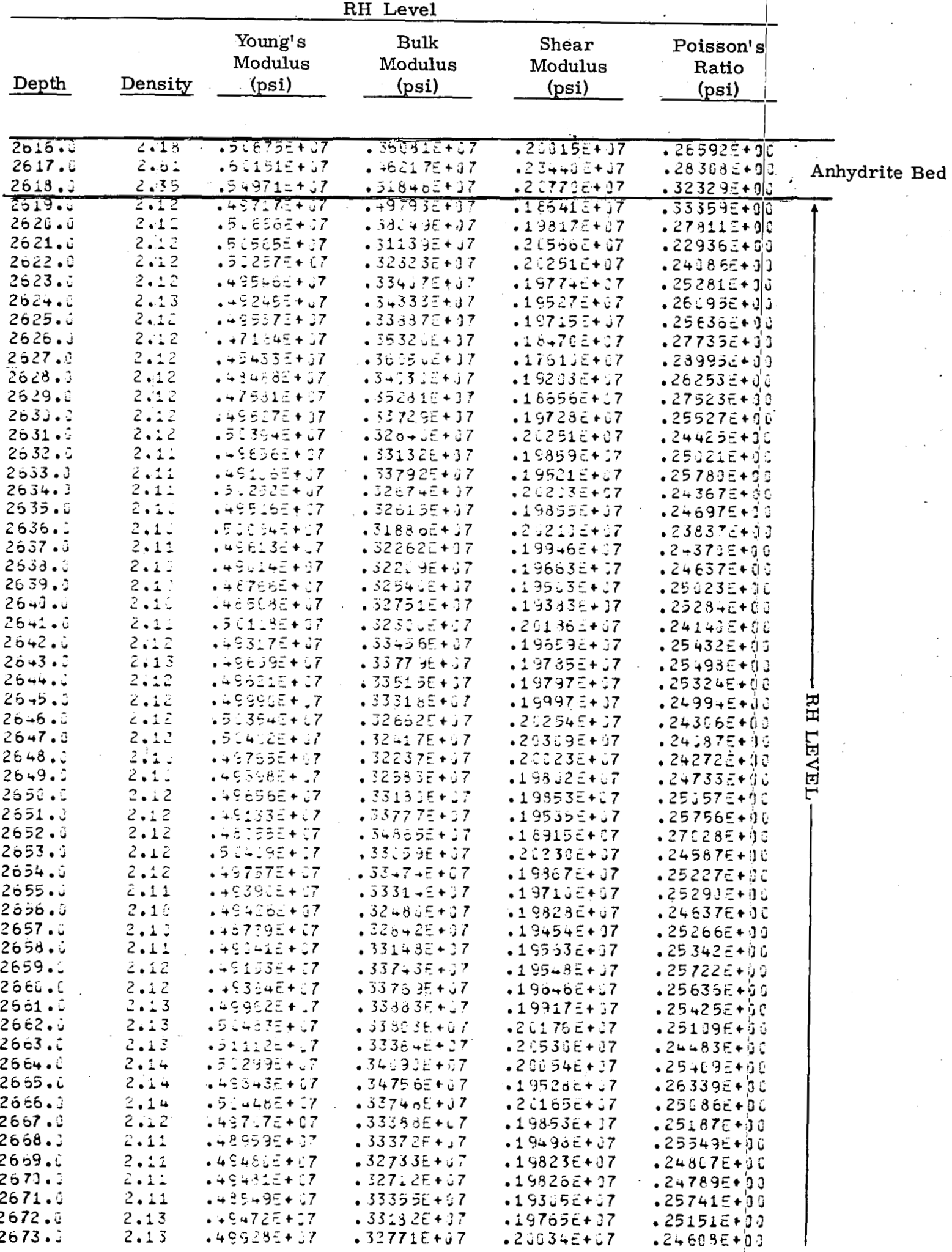


TABLE VIII (cont'd)

Physical Properties of Disposal Horizons

*

RH Level

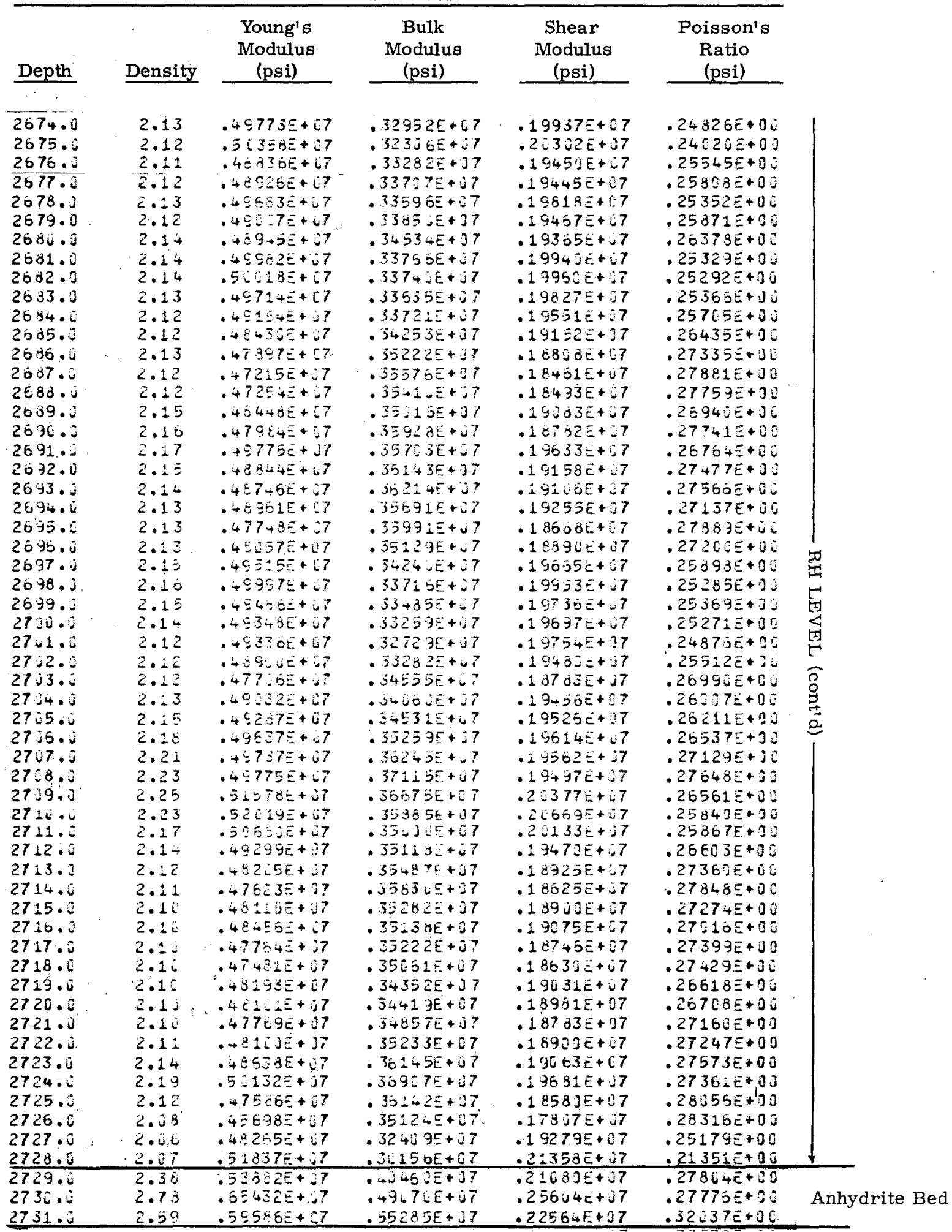


Sandia conducted 26 line miles of vibratory-type seismic surveys in the site area. In addition, 500 line miles of other deep-sounding seismic surveys have been obtained either by purchase or loan from private industry. Figure 26 presents the various surveys that were used to compile structural maps of the Castile and deeper horizons. Some difficulty was experienced in synthesis of the surveys because they involved different crews, instrumentation, and data processing. However, the interpretation is considered adequate for initial site evaluation.

Several structural anomalies we re noted on the seismic profiles, but fortunately none were discovered in the area proposed for actual mining. The more significant of these anomalies will now be described.

Anticlinal Feature Near Belco Hudson Federal No. 1 Well, Section 1, T23S, R30E -- An anticlinal feature exists that persists from the top of Salado down to the Devonian Marker. Sandia. Line 2 passed over this structure from northeast to southwest. The details of portions of that line are shown in Figure 25. The surface trace of the profile is shown on Figure 25. Only the shallow portion (Delaware upwards) of the profiles is shown. The anticline just described appears in the lower half of the diagram at Station 143. The Belco Hudson Federal No. 1 Well is $\sim 1000 \mathrm{ft}$ in front of this vertical profile. Note that the anticline gives way to a syncline at Station $i 55$. Complex structure is still evident to the southwest as far as Station 177. Structure along the Delaware sandstone horizon is rather mild, revealing only a gentle anticline centered under Station 155 . The complex structure in the Castile may represent salt flowage or deep removal of salt by groundwater.

Anticline in the Castile, Northwest Part, Section 21, T22S, R31E -- An anticline was shown on the structure map of the Castile, Figure 14. The details of the seismic profile over the feature are shown in the upper part of Figure 25. The crest of the anticline is at 3 tation 35 . Note that the two reflectors just above the Castile horizon marker appear to merge on the crest of the anticline (recall that the 124 Marker Bed structure map, Figure 13, reveals a synclinal structure for the Salado in this area).

Complex Feature, Northwest Part, Section 8, T22S, R31E - Note the position of a seismic profile line labeled "Cabin Lake 5 " on Figure 26. It is an east-west line about $8 \mathrm{mi}$ long with its center point on the northern boundary of Section 8, T22S, R31E. This line was run by an oil company, but permission had been granted to inspect but not copy the shallow portions of the data.

Normally the Delaware and Castile reflections are easily traceable on the section. However, the Castile reflections completely disappear for about $1 / 2 \mathrm{mi}$, even though/ the Delaware horizon continues in a normal fashion. The center of the Castile anomaly is in the/ northwest part of Section 8. This position is roughly congruent with a depression of the 124 Marker Bed, although the center of the latter is the southeast center of the same section (Figure 13). Lack of tight drill-hole control and wide spacing of seismic profiles could account for this discrepancy in position. The structure could be interpreted as a breccia pipe formed by deep-salt dissolution that has caused downward displacement of the anhydrite beds within the Castile. 
New seismic profiling recommenced in the site area under Sandia's direction during the fall of 1977. Full data reduction and interpretation of these new surveys will not be in hand until 1978. However, the initial interpretation of the records has verified the presence of this structure. In addition, a new feature of similar but less pronounced character has been recognized in the seismic data centered on the common corner of Sections 16, 17, 20, and 21, T22S, R31E. This location is at the northern boundary of Zone II.

While other structures were discovered during the study of seismic profiles available from several oil companies, the above three anomalies were the only significant ones found in the WIPP site area. "Seismic data from oil company records were not of sufficient quality to make a reliable interpretation of the complex Castile structure known to exist near ERDA No. 6. The profiles do reveal that the Castile is disturbed, but no definitive interpretation is possible.

\section{Magnetic Surveys}

Sandia purchased from private sources a 1-gamma-resolution airborne magnetic survey over the entire New Mexico portion of the Delaware Basin. In addition, a 10-gamma resolution was available from the USGS for much the same area. These two surveys have been reinterpreted to establish the strike trend of the lamprophyre dike that outcrops south of White City, NM; and that has been observed in two potash mines and in several deep oil tests. The course of the dike, shown in Figure 1, passes no closer than $7 \mathrm{mi}$ to Zone II of the proposed site, a distance considered to be far enough so as not to present a hazard. If other dike trends exist, the surveys were not of sufficient resolution to detect them.

The magnetic surveys do not reveal any sharp contrasts in the site area. Hence, no major basement structure is postulated under the site.

\section{Gravimetric Surveys}

Complete coverage of the New Mexico portion of the Delaware Basin was purchased from private sources. The station density is approximately $6.8 / \mathrm{sq}^{\circ} \mathrm{mi}$ and has been contoured on an interval of 0.2 milligal. Deep structural trends are evident. These features have been correlated with seismic interpretations to provide a structural trend map (Figure 14). The results indicate an east-west-trending belt of structural highs passing beneath the site area. North-trending highs are present to the east and west. The lows are sinuous and farther out. These structural trends are considered to be normal for a major depositional basin such as the Delaware.

\section{Schlumberger Expansion Arrays}

A total of 40 Schlumberger expansion array surveys were conducted in the site area. The location of these surveys is shown in Figure 27. Even though line lengths are long, each expander yields valid resistivity only in the central part of the line. The objective is to determine lithologic changes with depth, as shown by changes in electrical resistivity. The salt is highly resistive in relation to the siltstones and sandstones of the Dewey Lake and Santa Rosa Formations. If salt and 
anhydrite are present in the Rustler, they should show a corresponding increase in resistivity and can be detected. If the salt has been removed and the anhydrite converted to gypsum, then the surveys might reflect the top of the first salt in the Salado Formation. Unfortunately, the results of the field work do not support this hypothesis. Apparently, the varying thicknesses of the Santa Rosa and Dewey Lake beds overwhelm the electrical response of the underlying salt beds.

Detailed Electrical and Gravity Surveys Conducted Over Breccia Pipes Oultside the Site Area

Breccia pipes are known to exist in the Delaware Basin. While several specific hypotheses have been ventured for their origin, there is general agreement that dissolution of salt followed by collapse of the overlying strata is the essential process by which they are formed. All known pipes are in areas that have experienced major salt dissolutioning. That at least one penetrates as deep as the McNutt member of the Salado has been confirmed by underground exposures in the Mississippi Chemical Co. potash mine. Aerial views of this particular pipe and several others are shown in Figure 28. The surface topographic exposure of these particular pipes may be due to the fact that they are located within Nash Draw. It is conceivable that breccia pipes exist that do not express themselves topographically; and indeed, one having very little surface relief was accidentally encountered in the 1950s during the drilling of a potash exploratory hole in Section 12, T20S, R29E. Even though that particular pipe is $20 \mathrm{mi}$ northwest of the proposed site at|Los Medaños, it was sufficient warning to us that we should devise a method for detecting these /special structures. The Los Medaños area is relatively flat, and outcrops are covered with dune saind.

Detailed electrical resistivity and gravimetric surveys have been rur, over two known and three suspected pipes. The known pipes are the two previously described, the one encountered in the potash mine and the one discovered by an exploratory hole. The three/suspected pipes were distinctive topographic features near the one exposed in the mine (refer tolFigure 28). All of these locations are outside the area of investigation at Los Medaños, but they serve as case studies to determine the feasibility of detecting breccia pipes under shallow cover.

The electrical resistivity surveys employed an in-line pole-dipole te chnique. Both the dipole length and separation from the input pole were varied so as to determine experimentally the best configuration to reach below the surface weathering effects. This technique of geophysical surveying has proved successful in detecting the two known pipes. The surveys reveal that the breccia core has a much lower resistivity than the surrounding undisturbed strata. Results of profiling across the three suspected structures revealed that two are accompanied by prominent lows and are the refore thought to be breccia pipes (Hill A and B in Figure 28). The third (Hill D in Figurie 28) had no such low and is thought not to be a pipe. An example of the data derived over Hill A and Blis presented in Figure 29.

The same technique of measuring earth resistivity was applied in the shallow sink structure in the southeast part of Section 9, T22S, R31E. The results of that work are shown in Figure 30 . The data clearly show that it is a shallow feature that does not persist with depth. 
Gravimetric surveys were conducted over the same five known and suspected breccia pipes across which electrical surveys were conducted. The surveys were detailed and used the best available instrumentation and techniques. Station density was every $100 \mathrm{ft}$ over the suspected structures, plus a surrounding grid of 200-ft stations out at least two diameters from the pipes. All field measurements were reduced following conventional procedures for gravity data analysis. The detailed areas were contoured at $0.05-$ milligal intensities. These were then compared with a regional gravity map that was contoured on $0.20-$ milligal intervals.

The conclusion from the gravity work is that it was not a reliable indicator of the presence of breccia pipes. No abnormal high or low over the regional field was discernible.

\section{Mineral Resource Evaluation}

At the onset of the evaluation for the WIPP site location, we realized that some conflict with mineral resource was inevitable. The site was chosen in an attempt to minimize this conflict, but no details were available to quantify the extent of this conflict. Some potash drilling had been done in the area, but the data were not initially available to Sandia because such information is held in confidence by the USGS on behalf of the various mining companies who had done the drilling. Oil and gas production rates were known for proven reservoirs, but full exploration had not been conducted in the site area. In addition, the sudden advent of the energy crisis escalated the price of natural gas four-to fivefold in just the last $2 \mathrm{yr}$, causing interest in previously unattractive areas. The Morrow Formation is the principal gas-producing horizon in this portion of the Delaware Basin, but it was not considered to be an attractive exploration target before the price escalation. This is no longer true; deep exploratory drilling is now under way throughout the basin. Indeed, applications for drilling permits have been filed by three different companies in the Los Medaños site area in recent months.

\section{Oil and Gas}

The oil and gas potential now has been evaluated for the Los Medaños site and environs. The evaluator used the Delaware to Devonian structural maps that resulted from the seismic surveys to plan step-out wells to fully develop known fields as well as to plan wildcat tests to prospect likely structures. Production histories of surrounding wells were tabulated to predict total recoveries and decline rates associated with the withdrawal. Risk factors were assigned based on experience within the Delaware Basin. Conventional discounted cash-flow analyses were then used to calculate the present value of these resources. The potentially recoverable hydrocarbons, principally natural gas, were estimated assuming full and prudent development under current economics and technology.

The essential results of the oil and gas study are shown in Figure 32. The position of known and postulated reservoirs are shown superimposed on the Morrow Limestone structure. Known production in the area ranges from Delaware down to the Morrow Formation. However, the Delaware and Bone Springs are thought to be of only minor importance. Natural gas occurring in the Atoka and Morrow sandstones, both of Pennsylvanian age, hold the best promise for commercial production. 
There are two principal producing fields in the Los Medaños area. Five wells produce gas from the Morrow in a field known as Cabin Lake in the northwest. Another five-well field, called the Los Medaños Field, produces gas from both the Atoka and Morrow in the southwest part of the map area: Four other single-well fields produce from the Delaware, Bone Springs, A toka, and Morrow Formations. Fourteen dry holes have been drilled. Of these, only two were deep enough to penetrate the Pennsylvania; the other 12 tested only the Delaware Formation.

From the structure contours on Figure 32, it appears that a faulted anticline controls the Morrow reservoir in the Los Medanos field to the southwest of the site region. This same structure probably persists up into the Atoka. Therefore, the best opportunity for extension of both these reservoirs exists to the northeast.

Within the boundaries of the actual WIPP site, a pattern of faulted anticlines is shown. These structures are believed to hold promise for discovery of gas in the Morrow. Experience in other parts of the Delaware Basin has indicated a tendency for Morrow gas reservoirs to occur on the flanks of quaquaversal structures and noses.

To evaluate the hydrocarbon resources within the boundaries of the WIPP site, potential drilling sites were picked based on the structure contours of the Morrow. Depiending on structure and offset distance from producing wells, these potential drilling sites were rinked as either proven undeveloped, probable, or possible. These locations are shown in Figure 32. Two locations are considered proven undeveloped, and both are immediate offsets to a prolific A toka gas well in the southern part of Section 36, T22S, R30E. This particular well, known as the Shell James Ranch No. 1, has been partially surrounded by an arc of four other wells on the south and west that failed to tap the Atoka reservoir even though all four made successful completions in the Morrow. The production decline for the Atoka well indicates that the well is probably draining several square miles. This fact, coupled with favorable structure, indicates that immediate offsets to the northeast have a high chance of success. These wells will only enhance the rate of recovery of the Atoka reservoir now being drained by one well. Ultimate recovery will remain about the same. Four other prospective drilling sites were selected to fully develop the Morrowi reservoir in the Los Medaños Field. Two of these locations were ranked as "probable," and two were ranked as "possible."

The faulted anticlinal structure in the northwest part of the proposed land withdrawal area is considered more speculative than the northeast extension of the Los Medaños field. The Delaware, Bone Springs, and Atoka beds would be tested by any well going on down the Morrow Sandstone, but experience elsewhere in this part of the Delaware Basin indicates a low probability of striking commercial reservoirs. On the other hand, the chances of encountering gas in the Morrow are considered to be fairly good. Eleven drilling targets were selected for this area; 8 are considered probable and 3 as possible. Finally, four other locations were chosen to explore a structural nose located farther east. These four locations were assigned possible rankings for Morrow gas dis coveries. 
The potential gas that could be discovered and produced if the above hypothetical drilling program was executed is given in Table IX. The two Atoka wells will tap a reservoir that is now being efficiently drained by the Shell James Ranch No. 1. Therefore, little loss in resource is expected if the WIPP land withdrawal prevents drilling these two particular wells. However, these two drilling prospects have a good probability of extending the known Morrow reservoir in the Los Medaños Field, and prevention of drilling at those locations must be considered as a loss of those resources.

TABLE IX

Potential Economic Gas Resources Under WIPP Site

\begin{tabular}{|c|c|c|c|c|}
\hline \multirow{2}{*}{$\begin{array}{c}\text { Location } \\
\text { (Section/Township/Range) } \\
\end{array}$} & \multirow{2}{*}{$\begin{array}{l}\text { Expected } \\
\text { Reservoir } \\
\end{array}$} & \multicolumn{3}{|c|}{$\begin{array}{l}\text { Expected Reserve } \\
\text { (Billion } \mathrm{Cu} \mathrm{Ft} \text { ) }\end{array}$} \\
\hline & & $\underline{\text { Proven }}$ & Probable & Possible \\
\hline \multirow[t]{2}{*}{$\mathrm{N} 1 / 236,22 \mathrm{~S}, 30 \mathrm{E}$} & A toka & \multicolumn{3}{|c|}{--- Being Drained-n } \\
\hline & Morrow & 2.07 & -- & -- \\
\hline $\mathrm{W} 1 / 2 \quad 1,22 \mathrm{~S}, 30 \mathrm{E}$ & \multicolumn{4}{|c|}{ Outside WIPP Boundary } \\
\hline SW $1 / 431,22 \mathrm{~S}, 31 \mathrm{E}$ & Atoka & \multicolumn{3}{|c|}{ 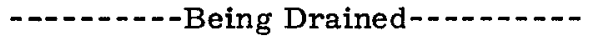 } \\
\hline & Morrow & 2.07 & -- & -- \\
\hline $\mathrm{NW} 1 / 431,22 \mathrm{~S}, 31 \mathrm{E}$ & Morrow & -- & 1.64 & -- \\
\hline $\mathrm{S} 1 / 225,22 \mathrm{~S}, 30 \mathrm{E}$ & Morrow & -- & -- & 1.33 \\
\hline $\mathrm{SW} 1 / 430,22 \mathrm{~S}, 31 \mathrm{E}$ & Morrow & -- & -- & 1. 33 \\
\hline $\mathrm{SE} 1 / 4 \quad 7,22 \mathrm{~S}, 31 \mathrm{E}$ & Morrow & -- & 2.09 & -- \\
\hline $\mathrm{SE} 1 / 413,22 \mathrm{~S}, 30 \mathrm{E}$ & Morrow & -- & 2.09 & -- \\
\hline $\mathrm{NW} 1 / 417,22 \mathrm{~S}, 31 \mathrm{E}$ & Morrow & -- & 2.09 & -- \\
\hline $\mathrm{NE} 1 / 417,22 \mathrm{~S}, 31 \mathrm{E}$ & Morrow & $\therefore$ & 2.09 & -- \\
\hline $\mathrm{SE} 1 / 416,22 \mathrm{~S}, 31 \mathrm{E}$ & Morrow & -- & -- & 1.67 \\
\hline $\mathrm{W} 1 / 424,22 \mathrm{~S}, 30 \mathrm{E}$ & Morrow & -- & 2.09 & -- \\
\hline SW $1 / 419,22 S, 31 \mathrm{E}$ & Morrow & -- & -- & 1.67 \\
\hline $\mathrm{NW} 1 / 419,22 \mathrm{~S}, 31 \mathrm{E}$ & Morrow & -- & 2.09 & -- \\
\hline $\mathrm{NE} 1 / 420,22 \mathrm{~S} ; 31 \mathrm{E}$ & Morrow & -- & 2.09 & -- \\
\hline $\mathrm{SE} 1 / 420,22 \mathrm{~S}, 31 \mathrm{E}$ & Morrow & -- & -- & 1.67 \\
\hline $\mathrm{NE} 1 / 421,21 \mathrm{~S}, 31 \mathrm{E}$ & Morrow & -- & 2.09 & -- \\
\hline $\mathrm{NE} 1 / 428,21 \mathrm{~S}, 31 \mathrm{E}$ & Morrow & -- & -- & 1.67 \\
\hline $\mathrm{SE} 1 / 433,21 \mathrm{~S}, 31 \mathrm{E}$ & Morrów & -- & -- & 1.67 \\
\hline $\mathrm{NE} 1 / 434,31 \mathrm{~S}, 31 \mathrm{E}$ & Morrow & -- & -- & 1.67 \\
\hline$\cdot$ & Totals & 4.14 & 18.36 & 12.68 \\
\hline & Grand Total & & & 35.18 \\
\hline
\end{tabular}

$\underline{\text { Potash }}$

Potash resource evaluation was more difficult and is not yet complete. This evaluation is being performed jointly by the USGS and the U.S. Bureau of Mines (USBM). The procedure was to in-fill drill between previously existing potash exploration holes (those that had been drilled by industry) at 
a minimum spacing of 1 hole/sq mi, or 21 new holes. Cores were taken continuously across the potential potash-bearing zones, selectively split, and then assayed. The results of these holes, along with information from the older privately drilled holes, allowed potential ore zones to be defined in plan, thickness, and grade. This phase of the evaluation was conducted by the USGS, but economic evaluation of this resource is the responsibility of the USBM. Mining methods and cost data have been accumulated from the existing mining operations in the immediate area.

Beneficiation testing on core samples has been done to determine what refining will be required and what percent recovery can be expected for the deposits under the Los Medaños site area. Discounted cash-flow analysis will be used to determine the present value of the resources.

The initial findings of the USGS indicate that potentially economic quantities of potash exist within the proposed site. The lateral extent of these deposits is presented in Figure 31 . It has been established policy within the USGS to consider as potential ore any deposit of potash mineralization that meets or exceeds these requirements: $4 \mathrm{ft}$ of 10 -percent $\mathrm{K}_{2} 0$ as sylvite, or $4 \mathrm{ft}$ of 4 -percent $\mathrm{K}_{2} \mathrm{O}$ as langbeinite or the equivalent combination of the two minerals. A "measured" reserve classification is given to those individual ore zones that have at least three sampled intercepts no farther than $1.5 \mathrm{mi}$ apart. Reserves are classed as "indicated" when the sample density is less, but where at least one intercept and reasonable geologic projection can be made. These standards are used by the USGS to determine if potash mineralization under federal lands qualifies for competitive bidding. All potash mineral lands in the Carlsbad district that meet these qualifications have been placed in an enclave called the Known Potash Area (KPA).

The position of the enclave as officially described by the USGS as of April 17, 1975, is posted on Figure 31. Our drilling of the 21 potash exploratory holes has demonstrated that much of the WIPP site area, originally mostly outside the KPA, would now fall within the minimum requirements set by USGS.

A more complete description of the data presented in Figure 31 will now be attempted. Langbeinite and sylvite ores are being currently mined in the extreme west part of the map area. The langbeinite is being extracted from the 4 th ore zone, and the sylvite is being mined from the 10 th ore zone. These are two of the traditional mining horizons known in the Carlsbad Potash District. Past mining and planned future extensions are shown. Plans are very tentative and are projected only for a few decades in advance of mining. Additional drilling or a change in market conditions could alter these plans. In addition, the plans are only of the existing Nash Draw mine now being operated by the Duval Corporation. Other mining leases exist in the area, but no plans have been submitted by the owners.

The USGS refined their estimates of ore to include a class higher than that required for land classification for competitive bidding. They set the higher criteria as $14 \% \mid \mathrm{K}_{2} 0$ for sylvite or $8 \% \mathrm{~K}_{2} \mathrm{O}$ for langbeinite while retaining the thickness and number of drill intercepts. A belt of higher-grade potash is shown that extends from Duval's Nash Draw mine on the west around the northern portion of the proposed WIPP site area. Four circular areas of indicated ore with these higher grades are also shown. 
The USGS has released their initial findings. Measured ore meeting the minimum criteria was found in the $2 \mathrm{nd}, 3 \mathrm{rd}, 4 \mathrm{th}, 5 \mathrm{th}, 8 \mathrm{th}, 9 \mathrm{th}$, and $10 \mathrm{th}$ ore zones. Deposits with the most economic potential occur in the 10 th and 4 th ore zones. The same conditions prevail under the higher grade requirements, but the potential tonnage decreases. Preliminary estimates for the WIPP site are given in Table X.

TABLE X

Potential Potash Reserves Under the WIPP Site

\section{Ore Zone}

4

10

All Others

Totals

otential Reserve, Tons x $10^{6}$

Potential Reserve, Tons $\times 10^{6}$

Minimum Grade

\section{Measured}

108.3

101.6

112.8

322.7
Indicated

$$
5.2
$$$$
5.9
$$

24.1

35.2
Higher Grade

Measured Indicated

58.5

0.3

47.7

3.3

$\underline{24.6}$

130.8
1.1

4.7

The USBM has not completed their economic evaluation to determine to what extent these measured and indicated reserves can be considered as actually mineable under today's market conditions and existing technology.

\section{Potential Geologic Hazards}

Investigations conducted at Los Medaños and reported here have found geologic conditions to be favorable to the proposed repository. Full confirmation of the site must await completion of detailed studies now under way. The work reported here is considered to be adequate to establish that the major selection criteria have been met. What follows is a discussion of some potential geologic hazards recognized in the surrounding areas that, if present in Zone II, might present a risk to terminal radioactive waste isolation. Additional geologic and geophysical investigations now under way at Los Medaños will determine additional geologic information relative to these potential hazards.

\section{Salt Flowage}

Highly deformed salt was revealed in the cores of halite beds from the Castile Formation in AEC No. 7. More intense deformation was observed in ERDA No. 6 and extended up in the section to the Cowden anhydrite. Examination of seismic profiles near the Capitan Reef has further substantiated the existence of a salt-deformation belt in front of that geologic feature. The selection of the Los Medaños site took this deformation belt into consideration. However, we assigned an arbitrary width of $6 \mathrm{mi}$ for the belt. Local deformation could extend farther out into the basin, particularly over or near any anticline or fault in the Delaware Mountain Group immediately underlying the 
Castile. Possible faults in the Delaware were observed on several seismic profiles, and their tentative positions are shown on Figure 15. Note that a shallow graben is shown between two of the northwest-trending faults. This minor structure could be the cause for the more complex structures seen in approximate juxtaposition in the 124 Marker Bed and in the Castile. (Figures 13 and 14).

The deformation belt in front of the reef is considered to have been formed by a décollement process initiated during the Tertiary Period when the entire Delaware Basin was tilted to the east. If correct, then all of the evaporite section should have had translation even though the intense deformation would be limited to near the Capitan Reef, which acted as an abutment. Some crinkling of halite beds sandwiched between anhydrite beds should be anticipated during such movement. In ERDA No. 9 the anhydrite lenses in the zone from the Cowden to the top of the Castile were essentially flat-lying, but at the contacts with halite there was some evidence of mixing that could be attributed to deformation. Salt recrystallization was also visible. A few thin anhydrite lenses were present in the thicker sections of infra-Cowden halite; frequently they exhibited contortion.

Brine and Gas Accumulations in the Salado

Brine and gas pockets are hit on an almost routine basis in the coujse of mining potash from the McNutt member of the Salado. The largest pocket reported containedlan estimated 100,000 gal of brine, but the average pocket is much smaller (10-100 gal). No quantitative measurements have been made on the gas volume or its in-situ pressure. The gas is mostly nitrogen; the brine is saturated in $\mathrm{Na}, \mathrm{Mg}, \mathrm{K}$, and $\mathrm{Ca}$ chlorides and sulfates. The presence of these pockets|has presented no major obstacle to potash mining, and the inference is that they will not present a hazard to WIPP mining operations. However, the presence of these fluid accumulations needs to be cited to correct the impression that salt beds are completely dry. The simpler geology (i.e., thick pure salt beds) selected for the repository mining levels is suggestive of a lesser frequency of occurrence of fluid-bearing lenses.

Table XI lists the known nitrogen gas "kicks" we witnessed in our exploratory drilling program: ERDA 9, ERDA 6, AEC 8, and AEC 7.

TABLE XI

Nitrogen Gas "Kicks"

\begin{tabular}{lc} 
Hole & Depth (ft) \\
\hline ERDA 9 & 1409 \\
ERDA 6 & 1841 \\
& 2021 \\
AEC 8 & $1100-1282$ \\
AEC 7 & 1610 \\
P-7 & $780-1234$ \\
P-12 & unknown \\
P-20 & unknown
\end{tabular}

Comment:s

Trace $\mathrm{H}_{2} \mathrm{~S}$

Blew for $30 \mathrm{~min}$

Blew for $45 \mathrm{~min}$

Produced $\mathrm{N}_{2}$ gas for seýeral mos

$\mathrm{N}_{2}$ gas. Blew for $1 \mathrm{hr}$

Numerous kicks

Hole unloaded drill fluid over a weekend shutdown. Depth thought to be $1300 \mathrm{ft}$.

Slight blow when hole reached final depth 
Perhaps the highest pressured zone encountered was in AEC No. 7, which was drilled by ORNL. It occurred after the planned total depth was reached and while the drill pipe was being removed before demobilization of the rig. The gas entry point was believed to be at a depth of $1610 \mathrm{ft}$. Some drilling fluid was ejected from the hole, but the blowout was exhausted in about $1 \mathrm{hr}$.

A nitrogen gas kick was initiated in AEC No. 8 on June 26, 1975. The hole had been left in a temporary abandoned condition by ORNL a little over a year; we were attempting to set a packer below the Culebra aquifer zone so as to complete the hole as an observation well. The tubing and packer assembly were ejected from the hole, and nitrogen gas continued to be emitted from the hole. The well was allowed to flow under open hole conditions for 2 mos with no noticeable depletion in flow rate. Subsequent flow tests were done in June 1976. The calculated open flow was $35,000 \mathrm{cu}$ $\mathrm{ft} / \mathrm{day}$.

Suberosion of Salt at the Base of the Evaporites and Relationship to Breccia Pipes and Geopressured Brine Reservoirs

Breccia pipes are known to exist in Nash Draw. They are a potential hazard that should be avoided because they may possess vertical permeability that could affect the long-term integrity of the repository. Under the previous section dealing with Geophysical Surveys, it was argued that such pipes can be detected by electric surveys. Such surveys are now being run over the site area, Inspection of aerial photos has revealed a circular but sand-dune-covered feature suggestive of an underlying pipe in the northwest part of Section 14, T23S, R30E. This location is only $4 \mathrm{mi}$ southwest of Zone II (Figure 3). The cluster of depressions shown on the top of Salado in Zone IV (Figure 12) surround the complex seismic anamoly where the Castile appears to be missing. A breccia pipe may be hidden under the flat sand-dune terrain in this area. If the collapsed breccia does not extend to the near surface, then it may not be detected by electrical surveys. High-resolution seismic profiling is being planned for this particular area.

The existence of breccia pipes is indicative of deep-solution cavities. As already mentioned, the pipe encountered in the Mississippi Chemical mine is proof that solution cavities have formed at depths at least as great as the base of the McNutt Member of the Salado. Deep solution could be occurring in the carbonate members of the Delaware Mountain or deeper horizons, but it is more reasonable to assume dissolution of the halites in the Castile or lower Salado.

The source of the dissolving fluid is more speculative. The largest nonsaline groundwater source is the Capitan Reef, and the numerous sinks in San Simon Swale are testimony that cavities are being formed in that area that overlies the reef. The swale is $20 \mathrm{mi}$ east of the site, but the arcuate-shaped front of the reef passes about $8 \mathrm{mi}$ from Zone II. The deformation belt in front of the reef could owe its existence to a combination of décollement of the evaporites due to regional tilting and salt dissolution from waters escaping from the reef.

Another possibility is that the deep dissolution front extends from the Pecos River and is thereby related to suberosion known to be acting at the top of the Salado. This implies that an undercutting wedge is working eastward. If so, then the discharge for the brine must be far to the south, 
probably well into Texas. A third source for water of low salinity would be upward movement of formation waters from the Delaware Mountain Group. The discharge could be northward into the reef or southward in solution channels at the base of the evaporites as was just postulated for waters associated with the Pecos River.

The existence of geopressured brine reservoirs in the Castile is further testimony that suberosion may occur at the base of the evaporites. The two nearest such reservoirs are shown on the geologic cross section (Figure 6). A summary of the flow rates from these and three other known occurrences is given in Table XII.

TABLE XII

Brine Flows From Nearby Wells

\begin{tabular}{lcccc}
\multicolumn{1}{c}{ Well Name } & \multicolumn{2}{c}{ Location } & Flow Rate (bbl/day) & $\frac{\text { Depth of Flow (ft) }}{\text { ERDA No. } 6}$ \\
Hudson Federal & Sec. 35, T21S, R31E & Sec. 1, T23S, R32E & 600 & 2709 \\
Culbertson-Erwin & Sec. 26, T22S, R32E & Strong & 2802 \\
Bootlegger Ridge & Sec. 36, T22S, R32E & 20,000 & 3515 \\
Gulf 1-A & Sec. 25, T22S, R32E & 36,000 & 3671
\end{tabular}

A drill-stem test was conducted in ERDA No. 6 to attempt to deterrnine the reservoir size. The test was not completely successful, but analysis of the data indicates that the reservoir ranges from 200,000-2,000,000 bbl. The other four wells were drilled by oil cornpanies who had no interest in the phenomena other than to get the wells back under control so that drilling could continue to deeper objectives. The stronger flow rates indicate that these brine wells tapped even larger reservoirs than we encountered at ERDA No. 6. The fact that these reservoirs are geopressured (i.e., they flow naturally) could be accounted for by collapse of over-lying beds. If this is the case, then such reservoirs may represent isolated pockets localized adjacent to remanent pillars of halite left behind a deep suberosion front. Hence, the flanks and any thicker-trian-normal section of Castile should be regarded with caution. No sharp anticline in the Castile hats been detected in the WIPP site similar to those at the Belco Hudson Federal No. 1 well or ERDA No. 6. However, a mild anticlinal structure is shown in the northeast part of Zone II (Figure 14). Nearby deep suberosion of Castile halite could have caused the structural lows observed on the structure map of the base of the 124 Marker Bed (Figure 13).

Studies are now under way to investigate deep suberosion phenomeria. The program will include seismic profiling and drilling. Additional flow testing of ERDA No. 6 is also planned. 
The northeast-trending dike previously mentioned is more than $70 \mathrm{mi}$ in strike length. The magnetic expression is indicative of a belt approximately 1 mi wide rather than a single narrow band as observed in the potash mines. Oil and gas tests have reported igneous material even farther out, suggesting that sills may have formed outward into the pre-Ochoan sediments. The strike of the dike structure parallels the western edge of Nash Draw and Quahada Ridge. This might suggest that the east side of Nash Draw, called Livingston Ridge, may reflect another structural trend. No indications of dikes coincident with this trend were detected in the aeromagnetic surveys.

\section{Conclusions}

The reconnaissance studies completed thus far form a sufficient base of information to determine that the Los Medaños site meets the essential criteria for terminal isolation of radioactive waste. The conflict with mineral resources is more subjective and the decision to preclude their eventual development must be made on the basis of national needs. That decision is not technical and will not be addressed further in this report.

The conceptual design for the WIPP project has indicated that only 3 sq mi will actually be needed for underground storage. This is the polygonal-shaped area centered on the common corner of Sections 20,21, 28, 29, T22S, R31E. Zones III and $I V$ are control zones beyond the repository to ensure the long-term integrity of the site. A review of the geologic structure maps, Figure 12-17, reveals that Zone II lies in an area of uniform and gentle dips on all horizons ranging down from the top of the Salado Formation to the Devonian Limestone.

The base of the 124 Marker Bed is stratigraphically about $475 \mathrm{ft}$ above the middle of the TRU mining level. The attitude of the 124 Marker Bed is north-striking, with a dip of about $50 \mathrm{ft} / \mathrm{mi}$ within the bounds of Zone II. This is considered to be very flat, and the same general conditions should persist down to the TRU mining level.

The middle of the RH'mining level lies $1025 \mathrm{ft}$ below the base of the 124 Marker Bed and 160 $\mathrm{ft}$ above the top of the Castile. There were insufficient drill-hole intercepts in the site area to compile a structure map of the top of the Castile. Instead, the most uniform seismic reflector within that formation was used to compile the structure shown in Figure 14. This horizon is estimated to be $900 \mathrm{ft}$ below the middle of the RH mining horizon. The middle of the Castile horizon reveals a closed anticline in the northeast corner of Zone II. The steepest dips are on the southwest flank of that anticline and are estimated at $250 \mathrm{ft} / \mathrm{mi}$. If the two postulated faults shown extending into the northwest corner of Zone II do in fact exist, then steep dips may be encountered in that area at the RH mining level. Experience would indicate that plastic flow within the salt has probably kept any faults of this magnitude tightly closed, and only a flexure in the pure salts would be expected at the mining levels. 
Suberosion of salt from the Rustler appears to be in various stages of development over Zone II. Rotary drilling through this zone of salt removal at ERDA No. 9, and subsequent hydrologic testing at the three hydrologic test locations (H-1, -2 , and -3 ) appears to indicate that complete subsidence has occurred, and there is no thick zone of brecciation. The suberosion process has not removed any salt from the Salado Formation in Zone II. The structural contours of this surface (Figure 12) and the isopach of the thickness between the top of the Salado and the base of the 103 Marker Bed (Figure 11) indicate no salt removal in Zones II and III. The suberosion front at the top of the Salado appears to be just entering Zone IV from the west-northwest. The two principal aquifers in the Rustler, the Magenta and Culebra, reveal (as expected) uniform dips that are in general agreement with the markers in the underlying Salado Formation.

The Dewey Lake Formation provides from 390-530 ft of cover over the Rustler in Zone II. Although the Santa Rosa has been stripped in the southwest quadrant, it pirovides additional cover of
up to $150 \mathrm{ft}$ in the northeast (Figure 10).

The surface of Zone II is completely sand-covered, and no topographic anomaly is present. The general drainage is to the southwest and conforms with the subsurface erosional pattern revealed on the isopachs of the Santa Rosa and Dewey Lake Formations.

The two mining horizons selected meet the general criteria for thickness and uniform physical properties for salt as determined from the wireline geophysical logs. In|addition, the chemical and $X$-ray analyses of drill cuttings taken every $10 \mathrm{ft}$ indicate the beds are $>95$ percent halite, with the remainder being anhydrite and minor clay. Visual examination of the core confirms these general conclusions. The results of drill-stem testing in ERDA No. 9 have given/proof that no anomalous quantities of brine or gases were present.

Mining operations for the WIPP program can be expected to encounter no more difficulties in excavation or ground support than have been learned in a half century of experience of potash mining in the Salado Formation. The beds selected for waste disposal are someiwhat deeper than the potash mining horizons, but the fact that mining will be conducted in near-pure halite rather than in a mixture of sylvite and halite should at least compensate for the added depth. Also, mining extraction will be held to a conservative 30 percent. versus the potash mining, which normally extracts 60 percent or more of the ore bed. 
The contributions of several individuals and companies are acknowledged by listing the various reports now on file with Sandia concerning Los Medanos site evaluation.

Shallow Seismic

Shallow Reflection Seismic Survey, Charles B. Reynolds \& Assoc., Inc. (6 pp, 31 fig.).

Deep Seismic

Colin McMillan, Los Medaños Area, Permian Exploration Co., July 1976 (4 pp, 5 fig.).

Inte rpretation of Geophysical Data, Los Medaños and Vicinity, G. J. Long and Assoc., Inc. , October 1976 (10. pp, 7 fig.).

\section{Electrical and Gravity}

Robert E. West and W. Gordon Wieduwilt, Experimental Geophysical Surveys of the Los Medaños Site and Surrounding Areas for Waste Isolation Plant Program, Mining Geophysical Surveys, December 1976 (45 pp, 6 fig.).

C. L. Elliot, An Experimental Detailed Gravity Survey of Known or Suspected Breccia Pipes at Weaver Hill, Hills A\&B, and Hills C\&D, Elliot Geophysical Company, December 1976, Vol. 1 to 3 .

C. L. Elliot, An Experimental Detailed Resistivity Survey of Known or Suspected Breccia Pipes and Sinkholes, Elliot Geophysical Company, December 1976 (39 pp, 1 fig.).

\section{Magnetic Surveys}

C. L. Elliot, A Preliminary Geophysical Study of a Trachyte Dike in Close Proximity to the Proposed Los Medaños Nuclear Waste Disposal Site, Elliot Geophysical Company, December 1975 (19 pp and 2 fig.).

\section{Physical Properties of Rocks and Cores}

C. L. Elliot, A Laboratory Investigation of Magnetic Physical Properties of Igneous Dike Samples from Kerr-McGee, Hobbs Plant, Section 31, T.20S., R.32E, Elliot Geophysical Company, December 1976 (10 pp).

C. L. Elliot, A Laboratory Investigation of Magnetic Density and Resistivity Physical Properties of Drill Core Samples from AEC No. 8 Well, Elliot Geophysical Company, December 1976 (14 pp).

C. L. Elliot, A Laboratory Investigation of the Density and Resistivity Properties of Drill Core Samples from ERDA No. 9 Geologic Investigation Well and USGS No. H-1 Hydrologic Investigation Well, Elliot Geophysical Company, December 1976 (11 pp).

\section{Geochemical}

J. E. Taggart and J. Renault, Mineralogical Analysis of Cuttings from Sandia WIPP Drill Hole No. 9, NMIMT, December 1976 (14 pp). 
J. E. Taggart and J. Renault, Mineralogical Analysis of Insoluble Residue from Sandia WIPP Drill Hole No. 9, NMIMT, December 1976 (2 pp).

Analytical Reports No. 676169 dated June 25, 1976; No. 776132 dated July 21, 1976; and No. 9761 dated September 2, 1976. (These reports give water soluble analysis and amount of insoluble residue of cuttings from 1076 to $2886 \mathrm{ft}$ in ERDA No. 9.) Martin Water Laboratories, Inc.

Geologic

C. L. Jones, B. M. Madsen, and D. F. Fuguas, Well Record, ERDA No. 9, U. S. Geological Survey, no date.

Roger Y. Anderson, Geologic Evaluation of the Los Medaños (ERDA No. 9) WIPP Site, UNM, November 1976 (28 pp), with addendum dated December 1976 (2 pp cind 2 fig.).

Roger Y. Anderson, Potential Geologic Hazards in the Los Medaños Area, UNM, September 1976 (9 pp).

\section{Drilling}

Hole History--ERDA No. 9, prepared by Fenix and Scisson, Consuling Engineers.

\section{Resources}

John Jay Keesey, Hydrocarbon Evaluation, Proposed Southeastern IJew Mexico Radioactive Material Storage Site, Vol. I and II, Sipes, Williamson and Aycock, Inc., September 1976 (28 pp and 26 fig.).

John Lorenz and Raymond Cheesman, Potash Ore Reserves in the Firoposed Waste Isolation Pilot Plant Area, USGS, 1977 (in preparation).

\section{Brine Reservoirs}

D. Tiab, Reservoir Calculations on Brine Accumulation at ERDA No. 6 and Other. Locations in the Vicinity of the Los Medaños Site, NMIMT, March 1977 (7 pp)

Walter Rose, Development of a Cónceptual Model to Explain Brine Filowage into Wells Drilled Through the Salado-Castile Formation in Locations such as ERDA No. 6 Site, NMIMT, March $1977(12 \mathrm{pp})$. 
DISTRIBUTION:

\section{U.S. Department of Energy}

Waste Repository Branch/WPR

Washington; DC 20545

Attn: D. L. Vieth, Acting Chief

U.S. Nuclear Regulatory Commission High-Level and Transuranic Waste Branch Division of Fuel Cycle and Material Safety Washington, DC 20555

Attn: J. C. Malaro, Chief

U. S. Department of Energy (13)

Albuque rque Operations Office

P. O. Box 5400

Albuquerque, NM 87115

Attn: D. Davis, Jr., Director, Nuclear Materials and Waste Mgmt. Div. N. H. Mackay

W. P. Armstrong (10)

Reading Room 1

U. S. Geological Survey (2)

Stop 966, Box 25046, Bldg. 25

Denver Federal Center

Denver, CO 80225

Attn: C. L. Jones

W. S. Twenhofel, Chief Special Projects Branch

U. S. Geological Survey

P. O. Drawer 1857

Roswell, NM 88201

Attn: M. Millgate

U. S. Geological Survey (2)

P. O. Box 4369

Albuquerque, NM 87106

Attn: J. Mercer

W. E. Hale, Hydrology Branch

U.S. Department of the Interior (2)

Bureau of Mines

Bldg. 20, Federal Center

Denver, CO 80225

Union Carbide Corporation

Bldg. 9102-2

P. O. Box $Y$

Oak Ridge, TN 37820

Attn: W. C. MeClain

Bechtel, Inc.

Business Development Nuclear

Fuels Programs

P. O. Box 3965

San Francisco, CA 94119

Attn: H. L. Browne, Manager
New Mexico Institute of Mining and Technology (6)

Socorro, NM 87801

Attn: M. Wilkening, Chairman

Governor's Subcommittee on Radioactive Waste Management

New Mexico Environmental Improvement Agency (2) P. O. Box 2348

Santa Fe, NM 87501

Office of the State Geologist

P. O. Box 2860

Santa Fe, NM 87501

Bureau of Land Management

P. O. Box 1397

Roswell, NM 88201

Attn: J. H. O'Conner, Area Manager

Bureau of Land Management

P. O. Box 1449

Santa Fe, NM 87501

Attn: R. Casebeer

Soil Conservation Service

P. O. Box 2008

Albuque rque, NM 87103

Attn: A. W. Hamelstrom Acting State Soil Scientist

New Mexico State Land Office

P. O. Box 1148

Santa Fe, NM 87501

Sandia Laboratories (5)

Carlsbad Office

1502 West Stevens St.

Carlsbad, NM 88220

Attn: J. E. Magruder (4)

Reading Room (1)

1100 C. D. Broyles

1133 R. D. Statler

5000 A. Narath

5300 O. E. Jones

5310 W. E. Weart

5311 L. R. Hill (20)

5311 G. E. Barr

5311 J. P. Brannen

5311. S. J. Lambert

5311 M. A. Molecke

5311 D. W. Powers

5311 A. R. Sattler

5311 S. E. Shaffer

5311 J. R. Wayland

5314 M. L. Merritt

5314 F. W. Bingham 
DISTRIBUTION: (Cont'd)

$\begin{array}{ll}5330 & \text { R. W. Lynch } \\ 5333 & \text { B. D. Zak } \\ 5335 & \text { H. D. Sininski } \\ 5337 & \text { L. D. Tyler } \\ 5337 & \text { J. L. Krumhansl } \\ 5337 & \text { A. R. Lappin } \\ 5337 & \text { R. C. Lincoln } \\ 5341 & \text { L. W. Scully } \\ 5341 & \text { P. D. O'Brien } \\ 5341 & \text { R. E. Stinebaugh } \\ 5341 & \text { H. C. Shefelbine } \\ 5341 & \text { W. E. Wowak } \\ 5342 & \text { J. W. McKiernan } \\ 5342 & \text { D. J. Hosterman } \\ 5342 & \text { H. C. Walker } \\ 5400 & \text { A. W. Snyder } \\ 5413 & \text { P. E. McGrath } \\ 5700 & \text { J. H. Scott } \\ 5730 & \text { H. M. Stoller } \\ 5732 & \text { D. A. Northrop } \\ 5732 & \text { G. B. Griswold (20) } \\ 9517 & \text { F. L. McFarling } \\ 9517 & \text { R. C. Mueller } \\ 8266 & \text { E. A. Aas } \\ 3141 & \text { C. A. Pepmueller (Actg) (5) } \\ 3151 & \text { W. L. Garner (3) } \\ & \text { For DOE/TIC (Unlimited Release) } \\ \text { DOE/TIC (25) } & \text { (R. P. Campbell, 3172-3) }\end{array}$

(R. P. Campbell, 3172-3) 

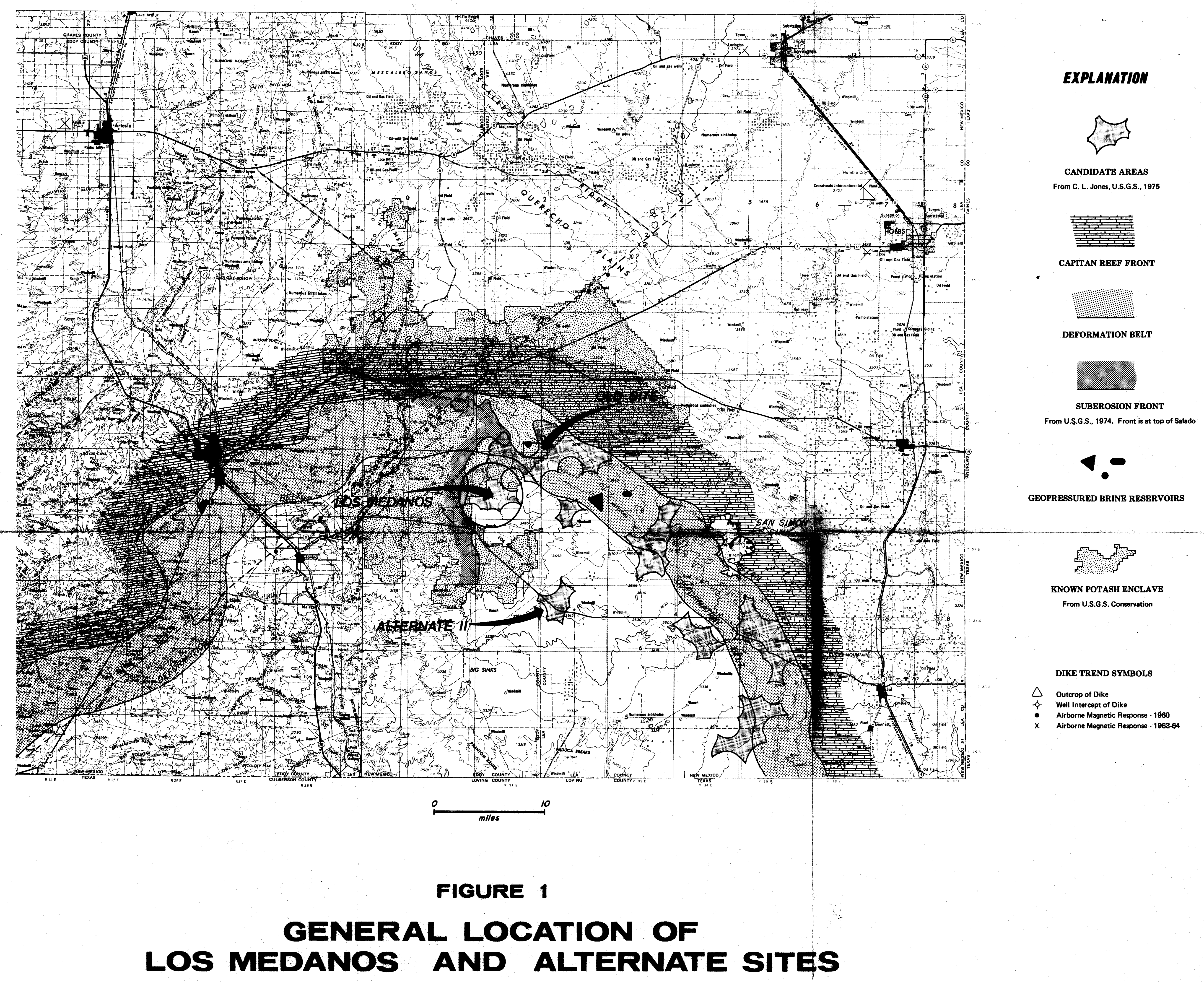

FIGURE 1 LOS MEDANOS AND ALTERNATE SITES 


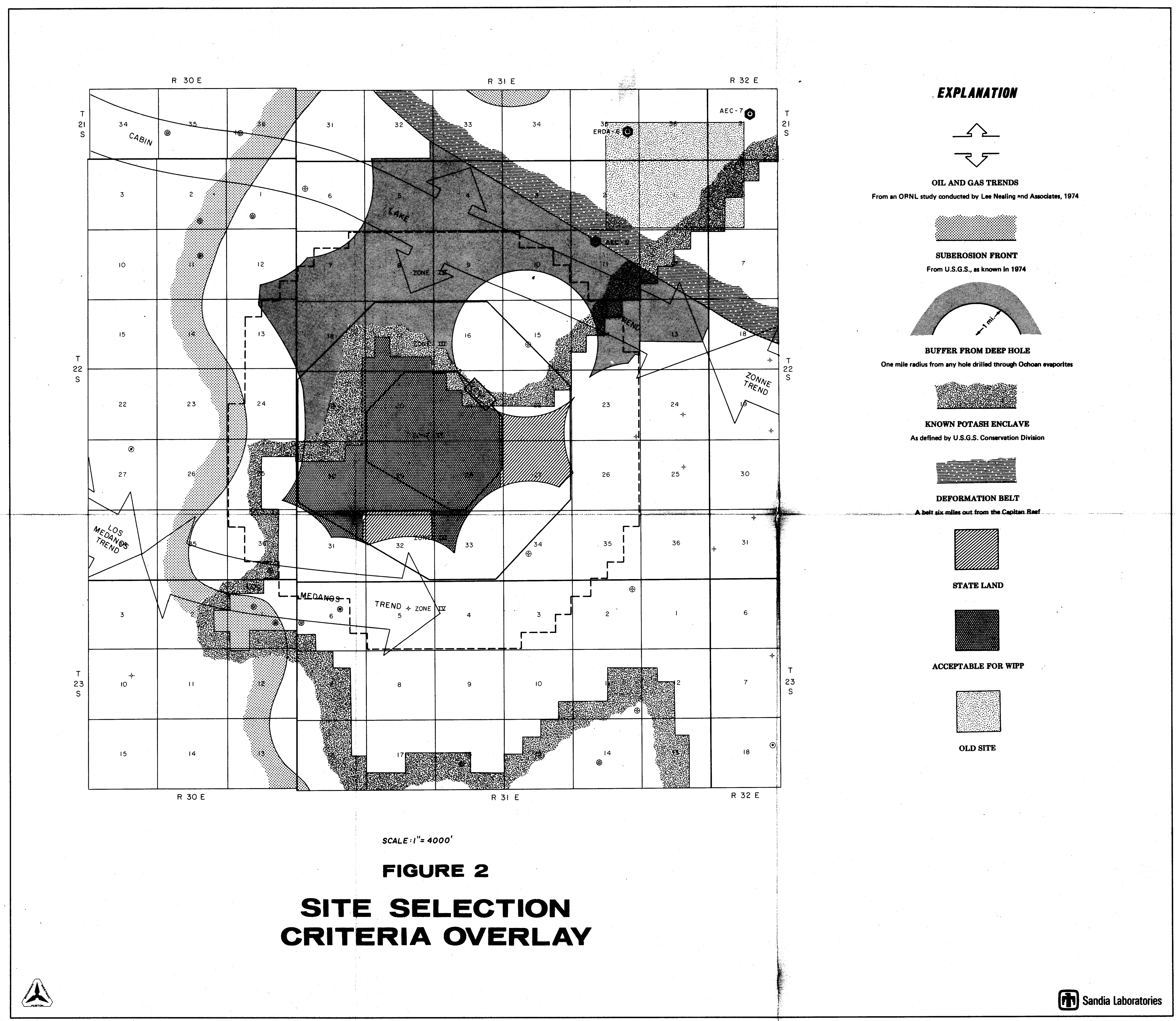



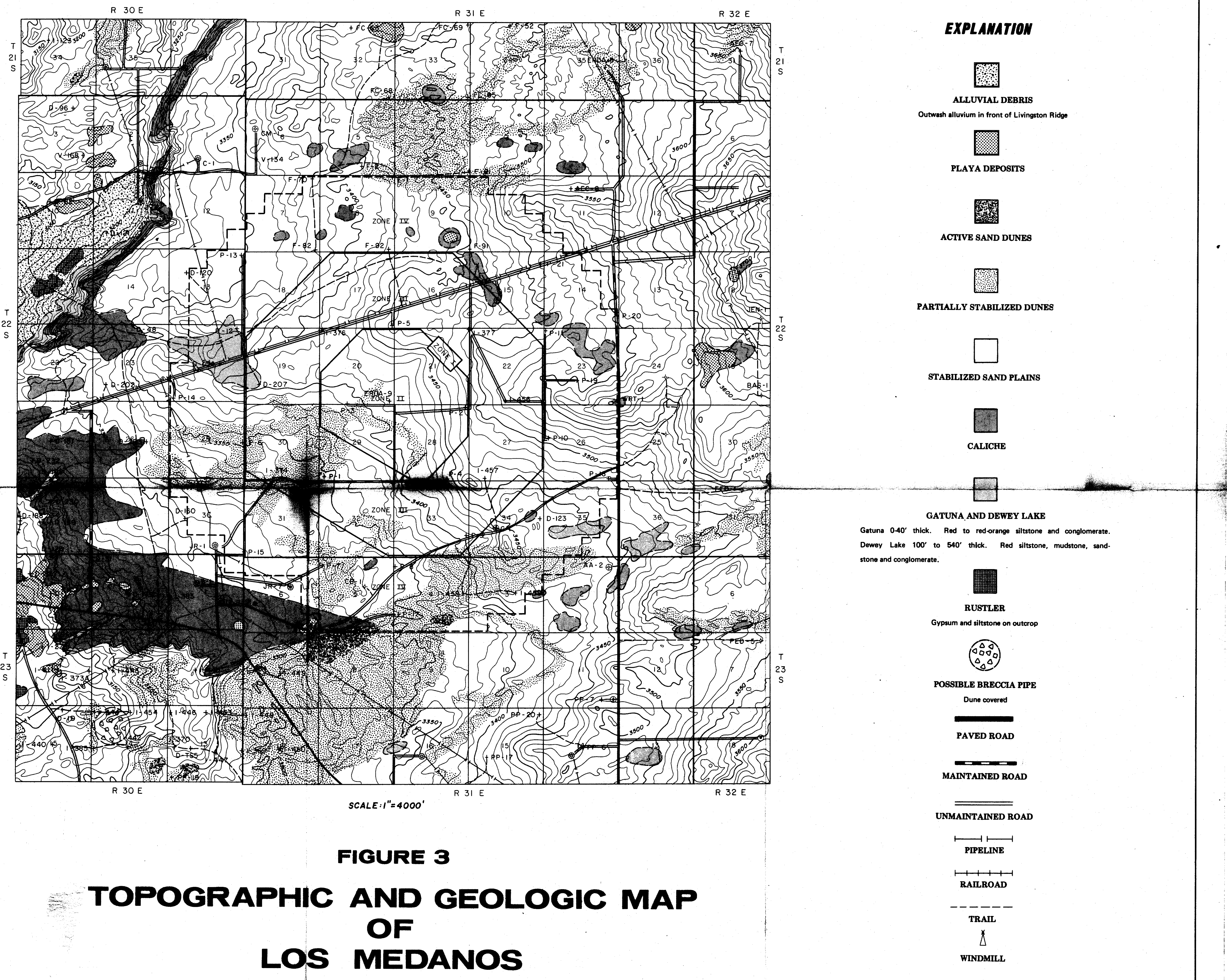


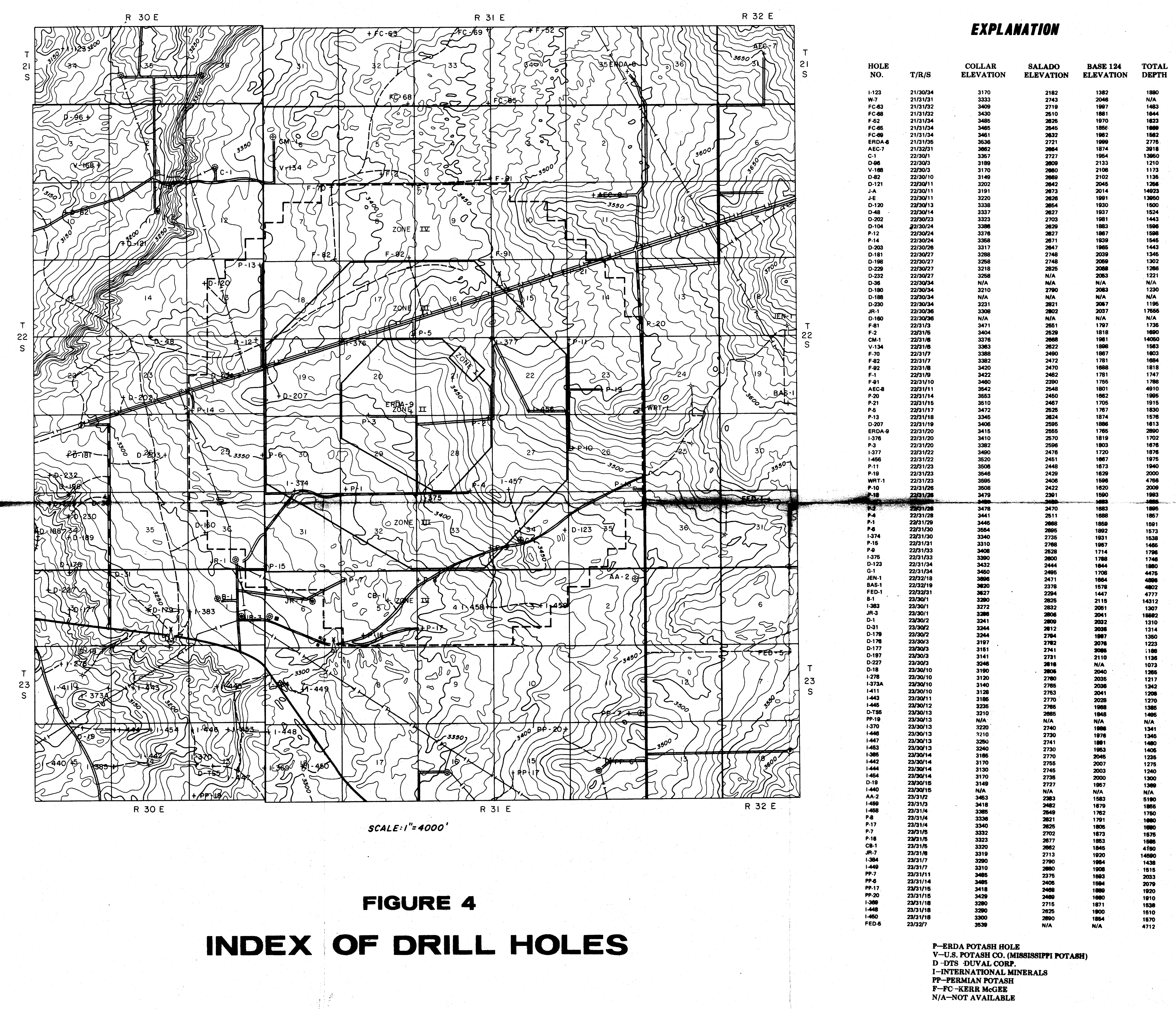




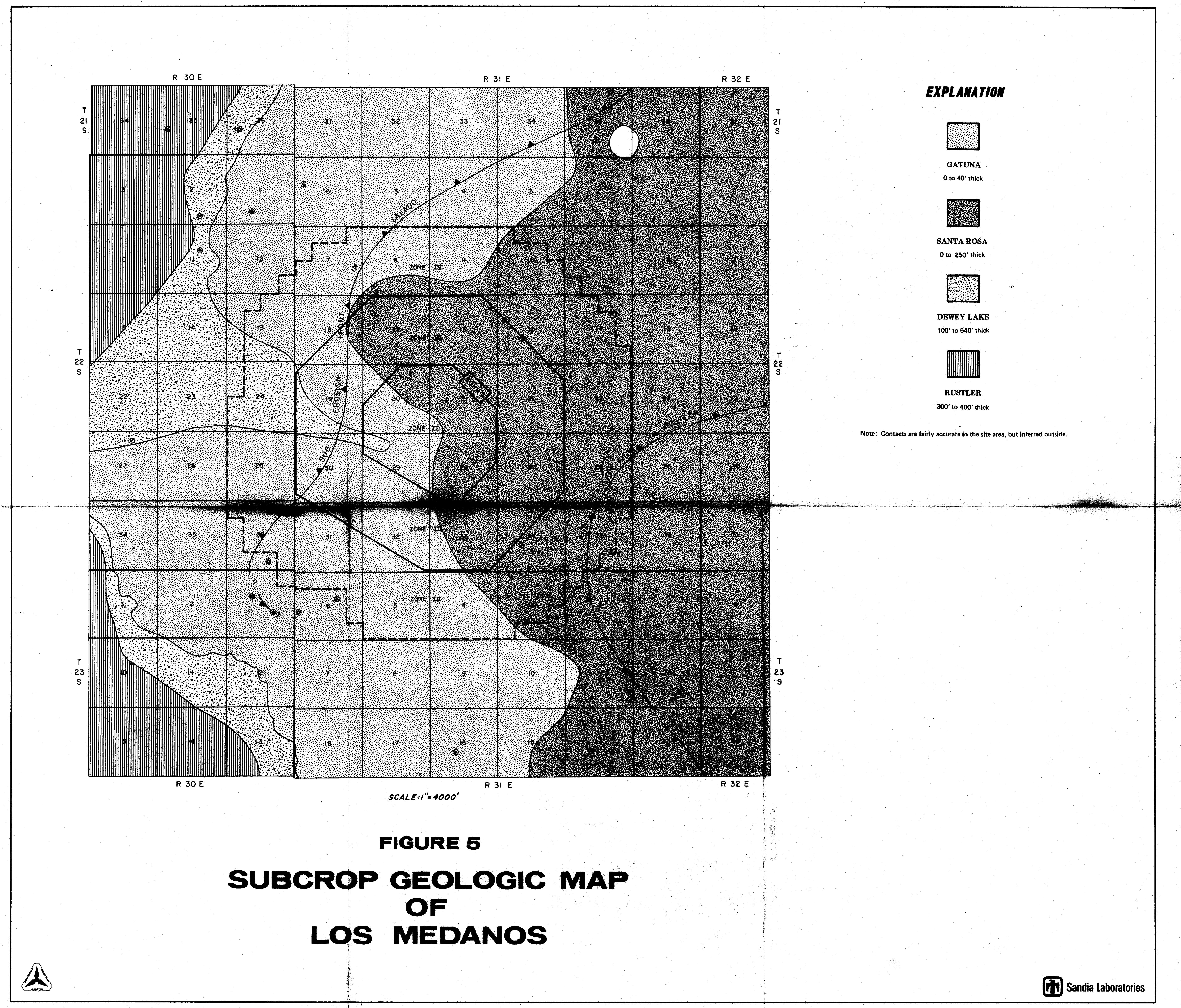




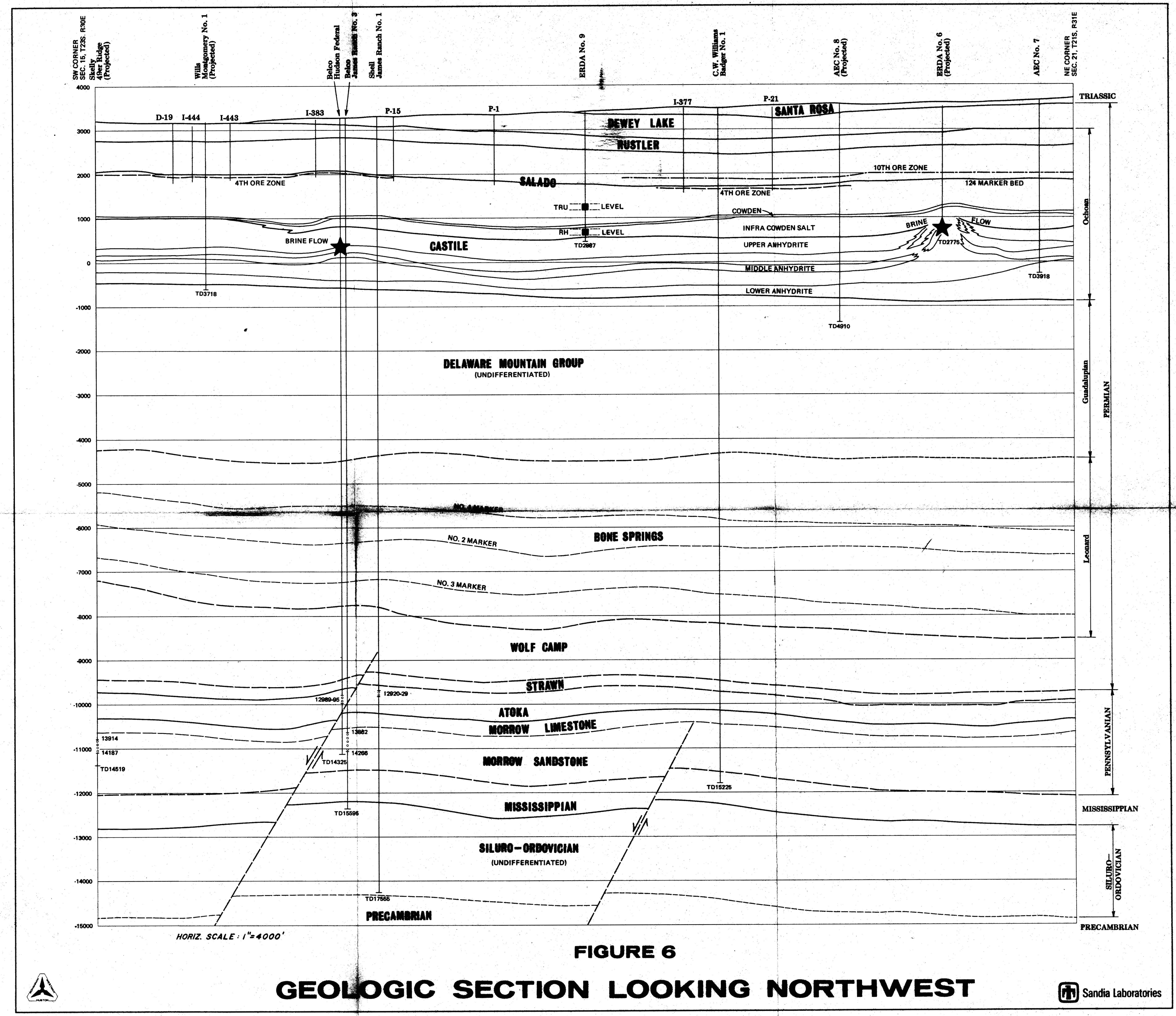




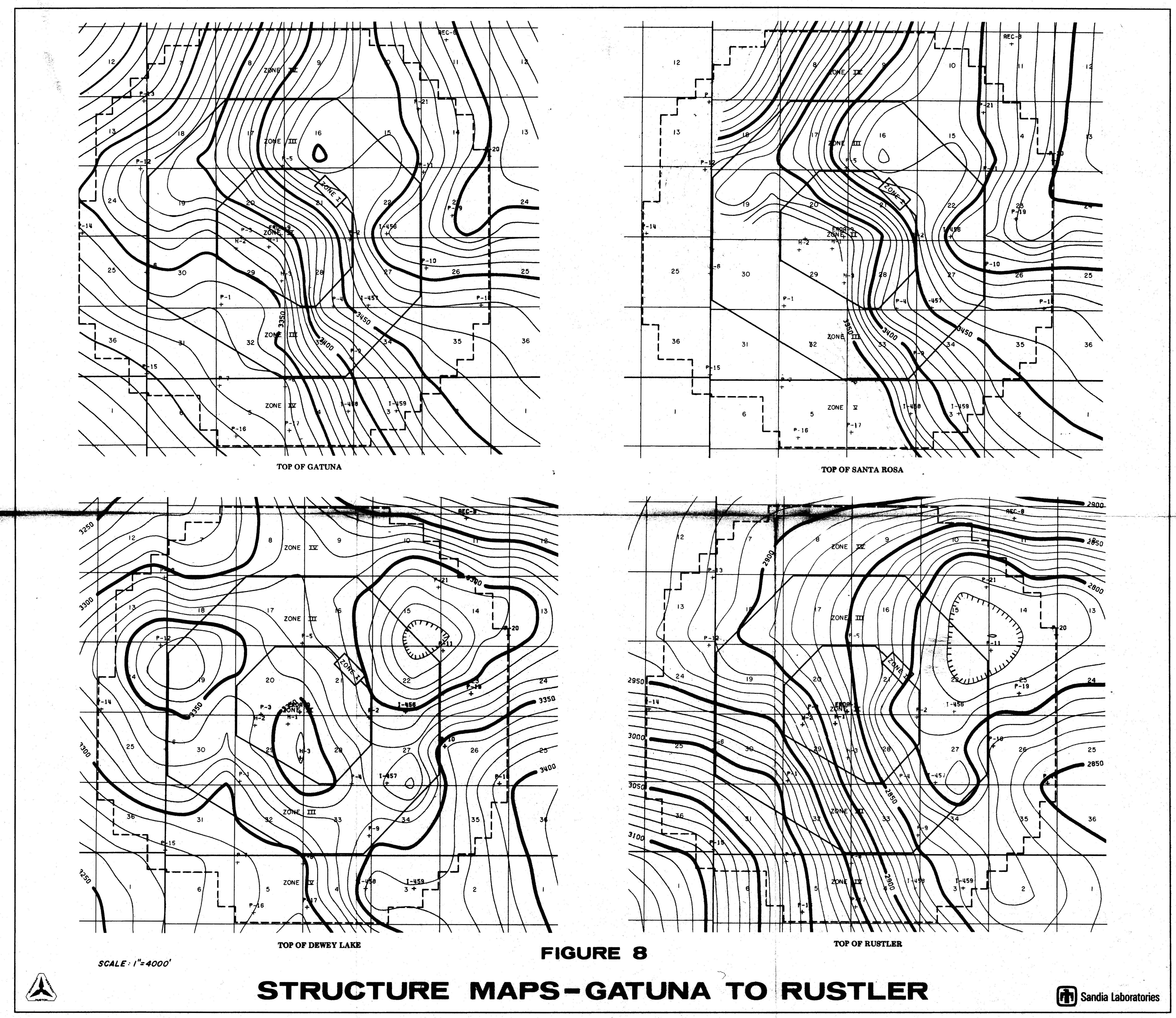



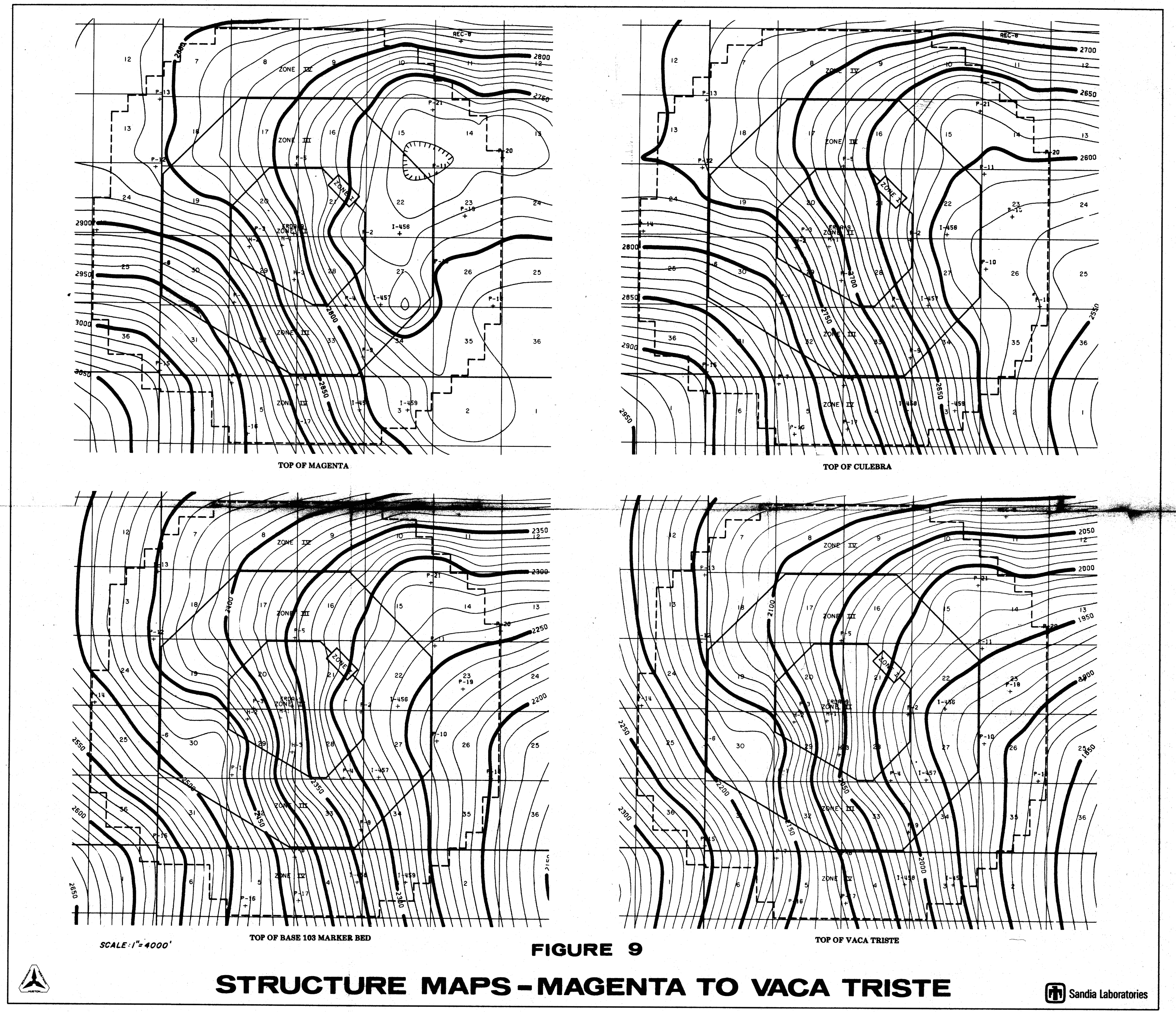

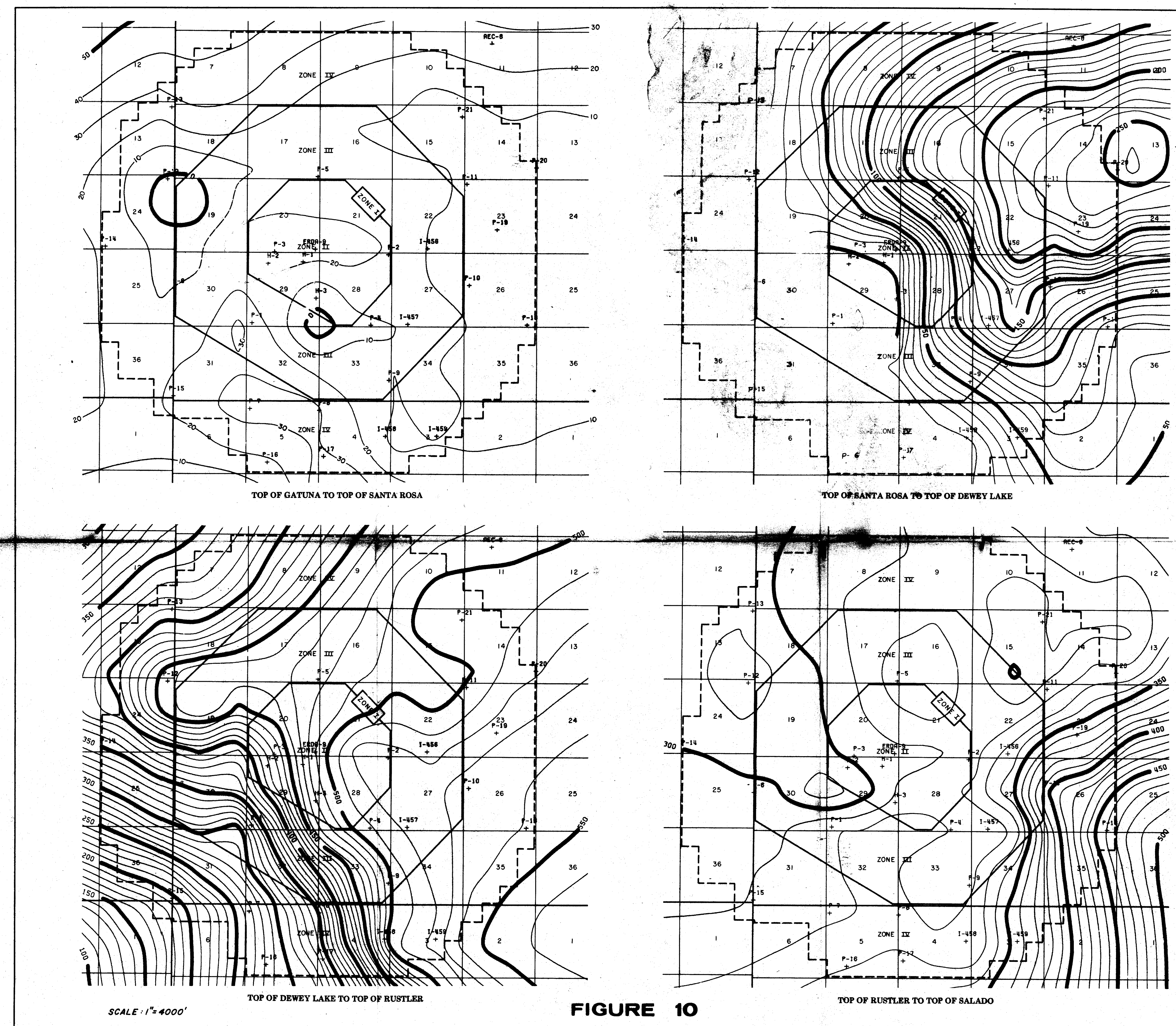

FIGURE 10

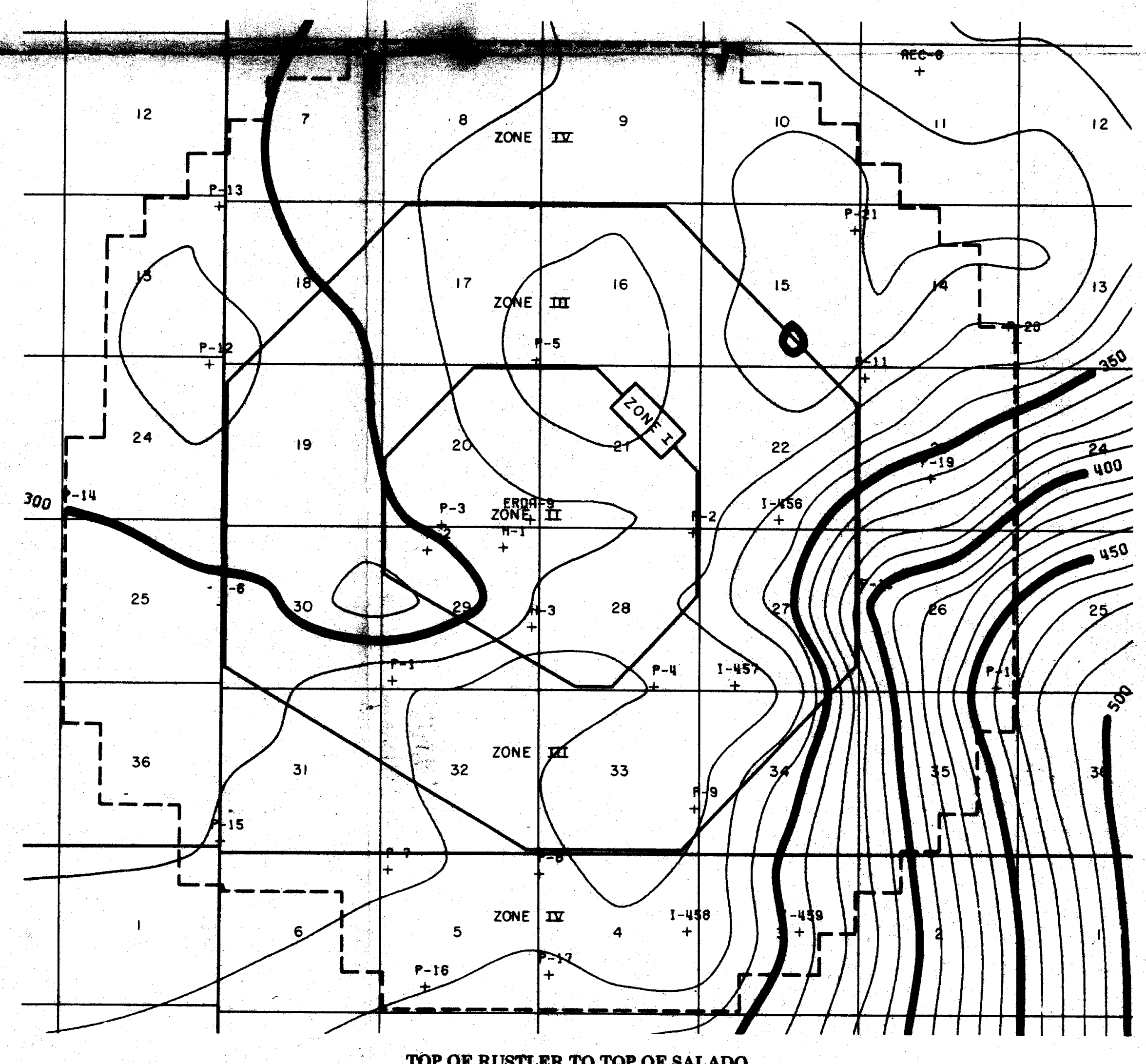




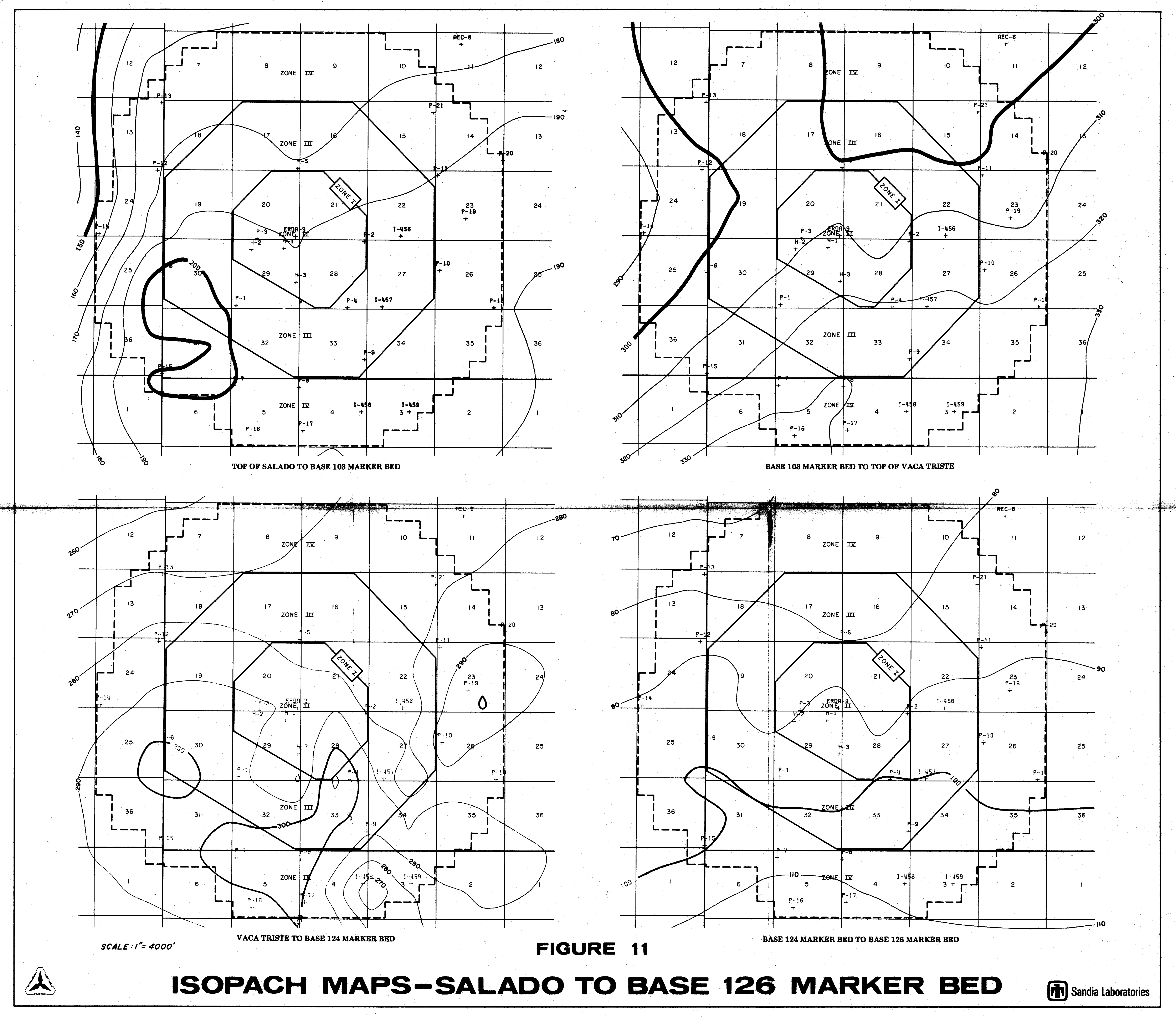




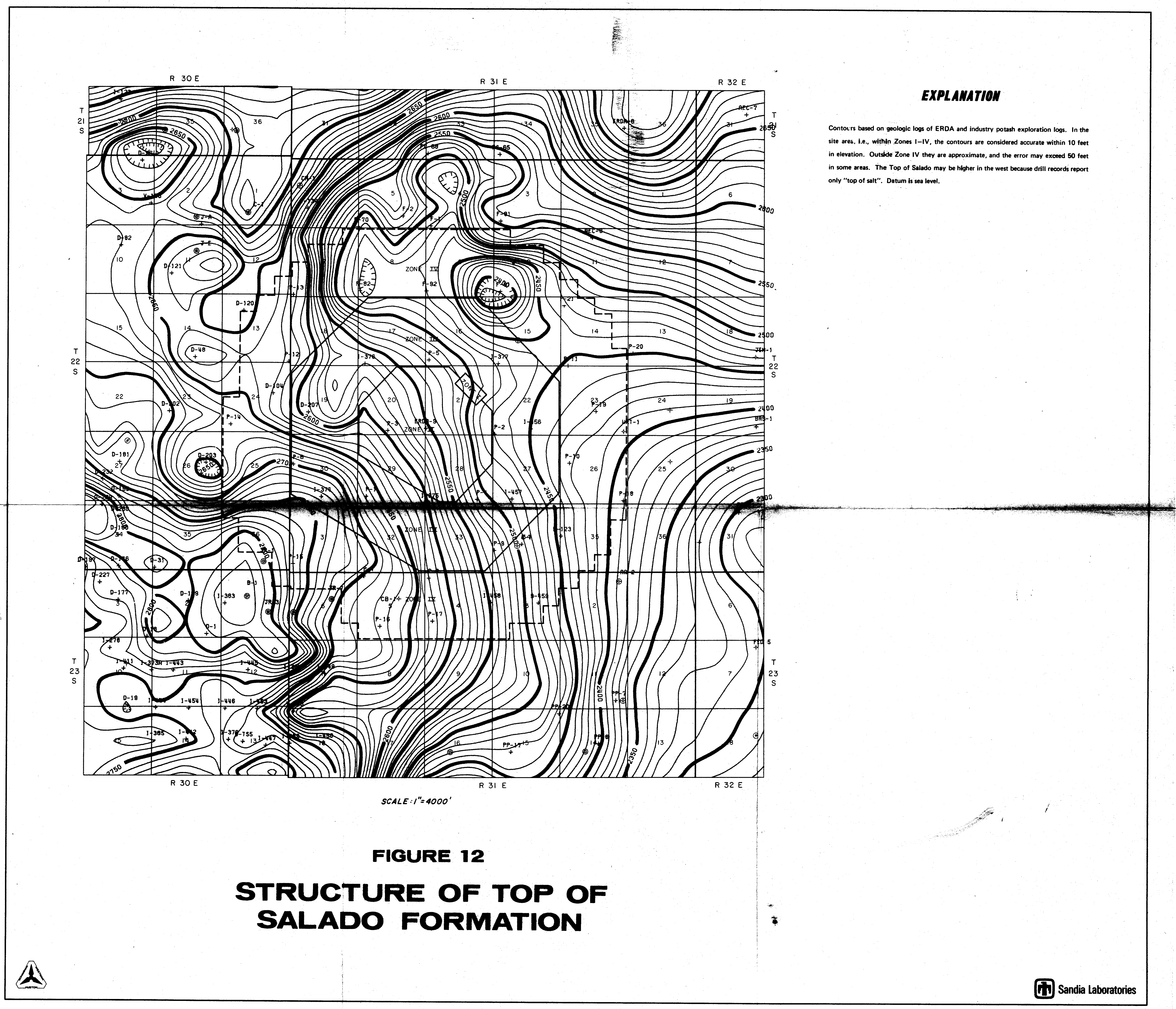




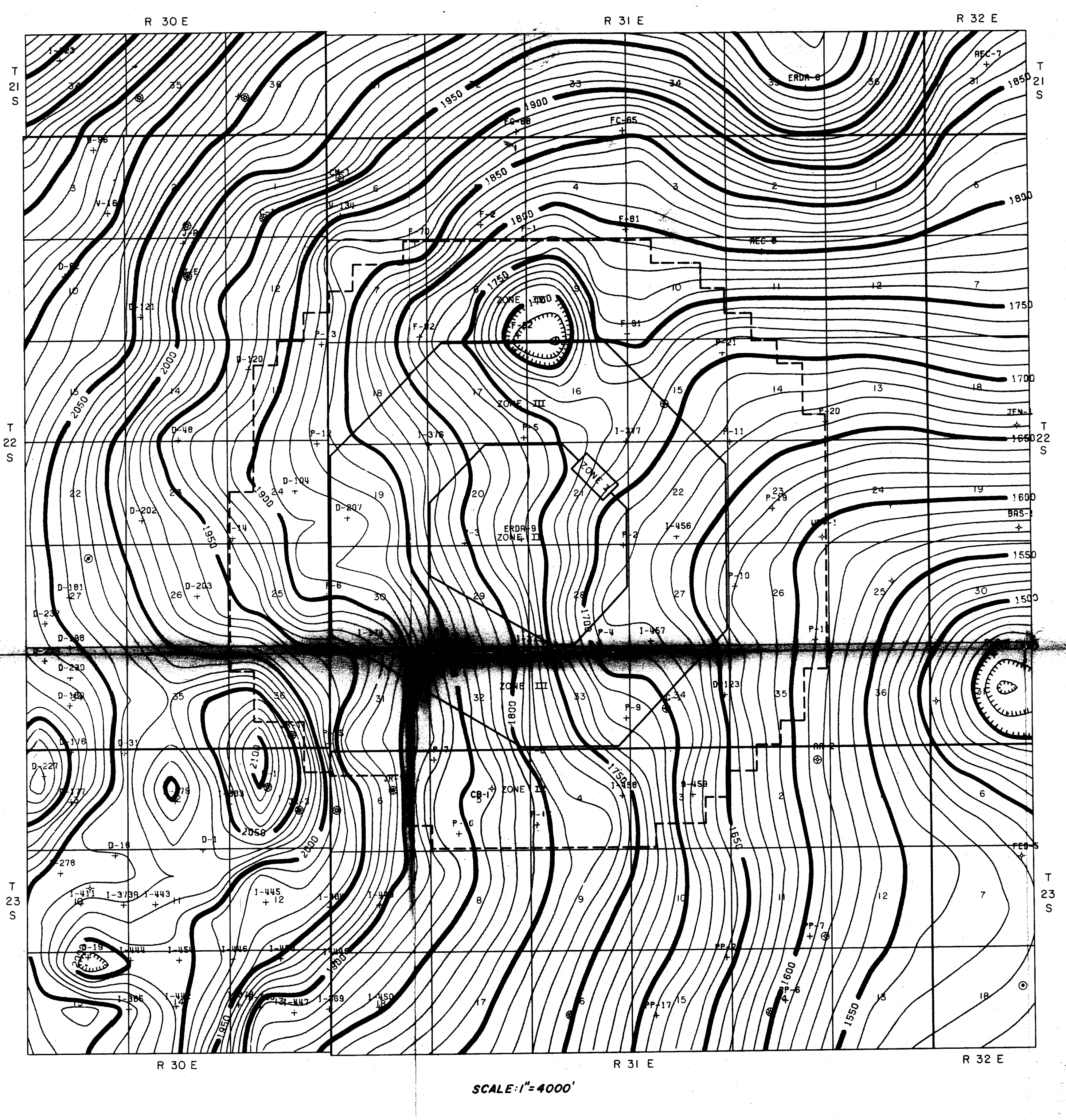

EXPLANATION

was taken from industry holes. Don. May be as

FIGURE 13

STRUCTURE OF

BASE 124 MARKER BED 


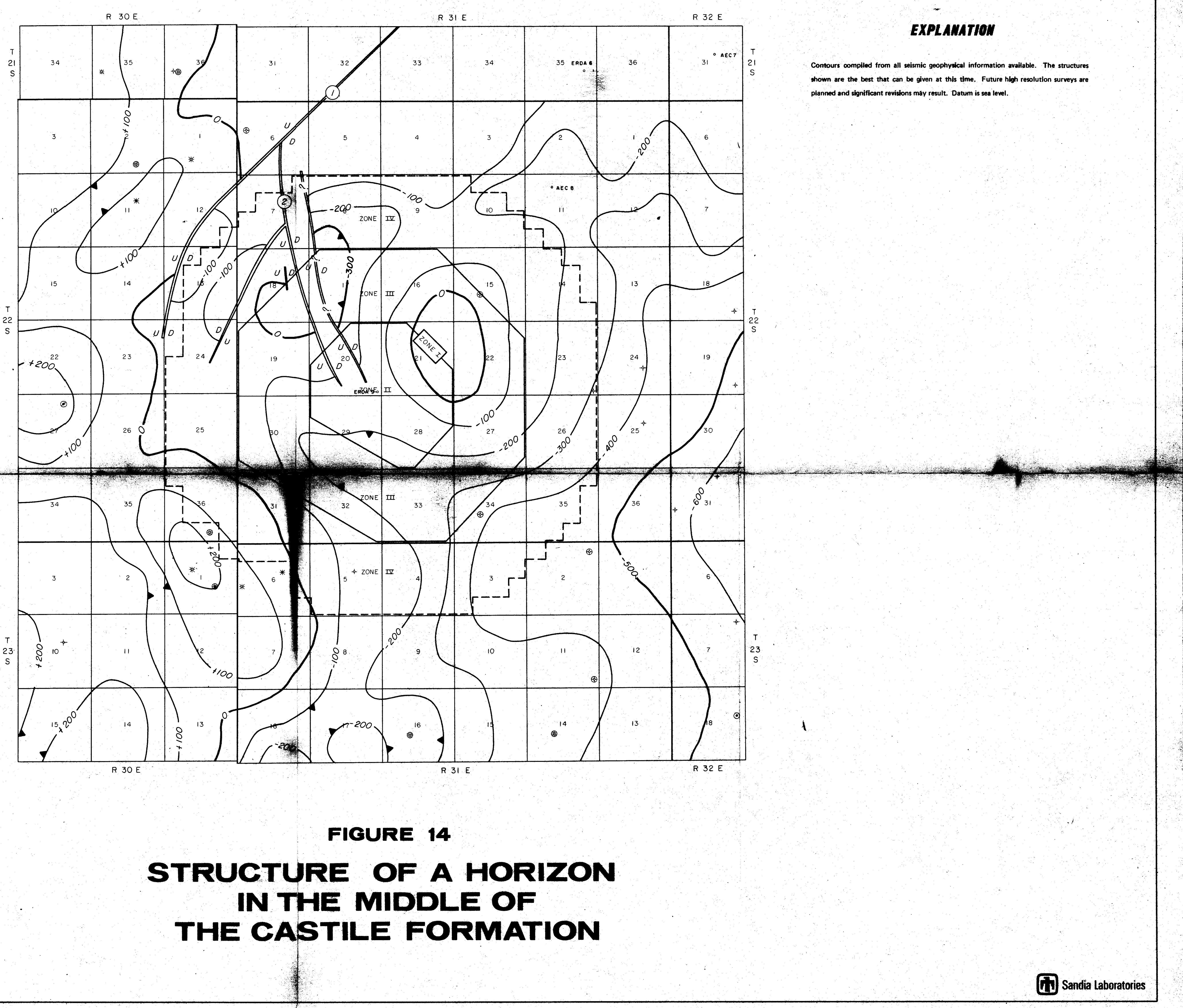




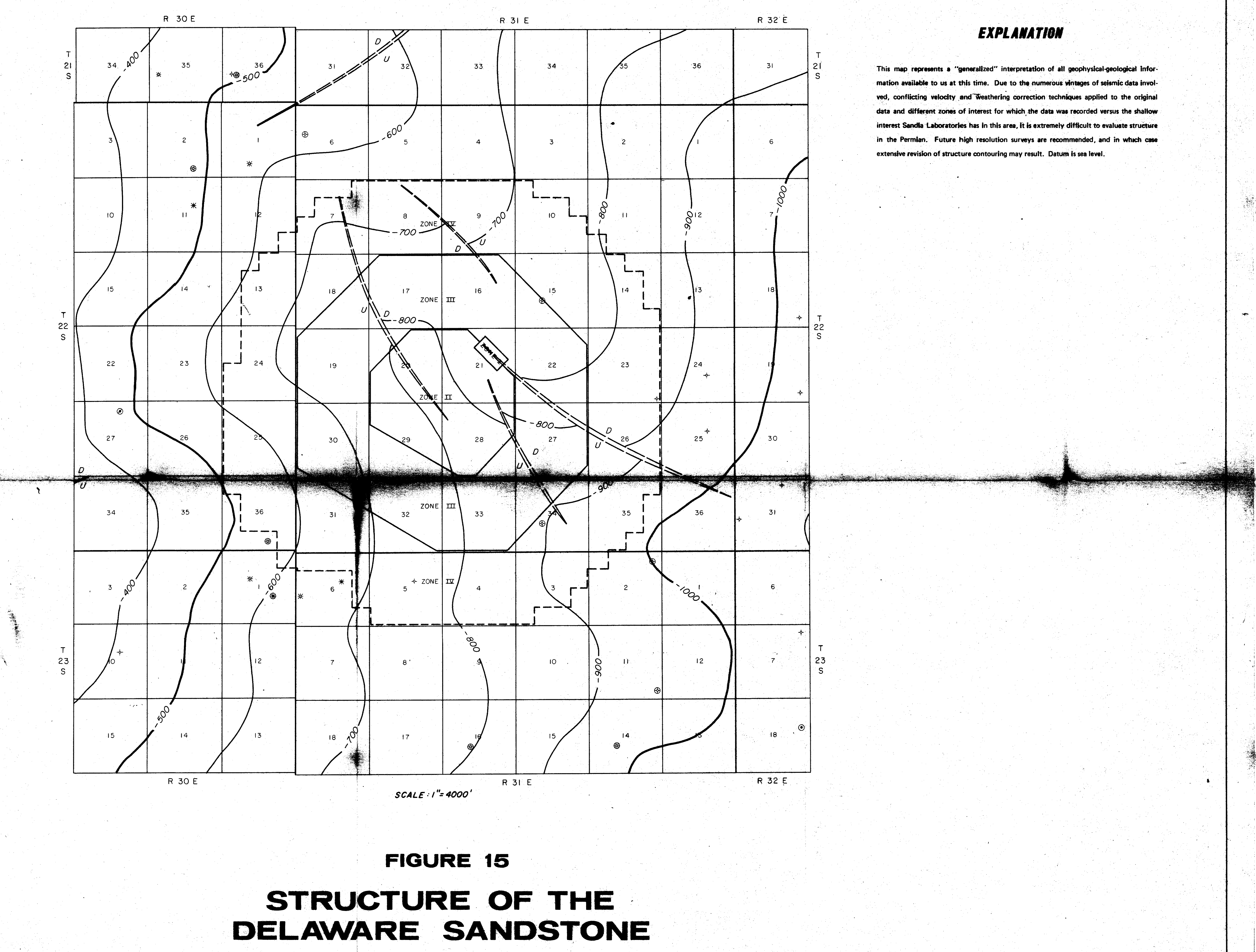




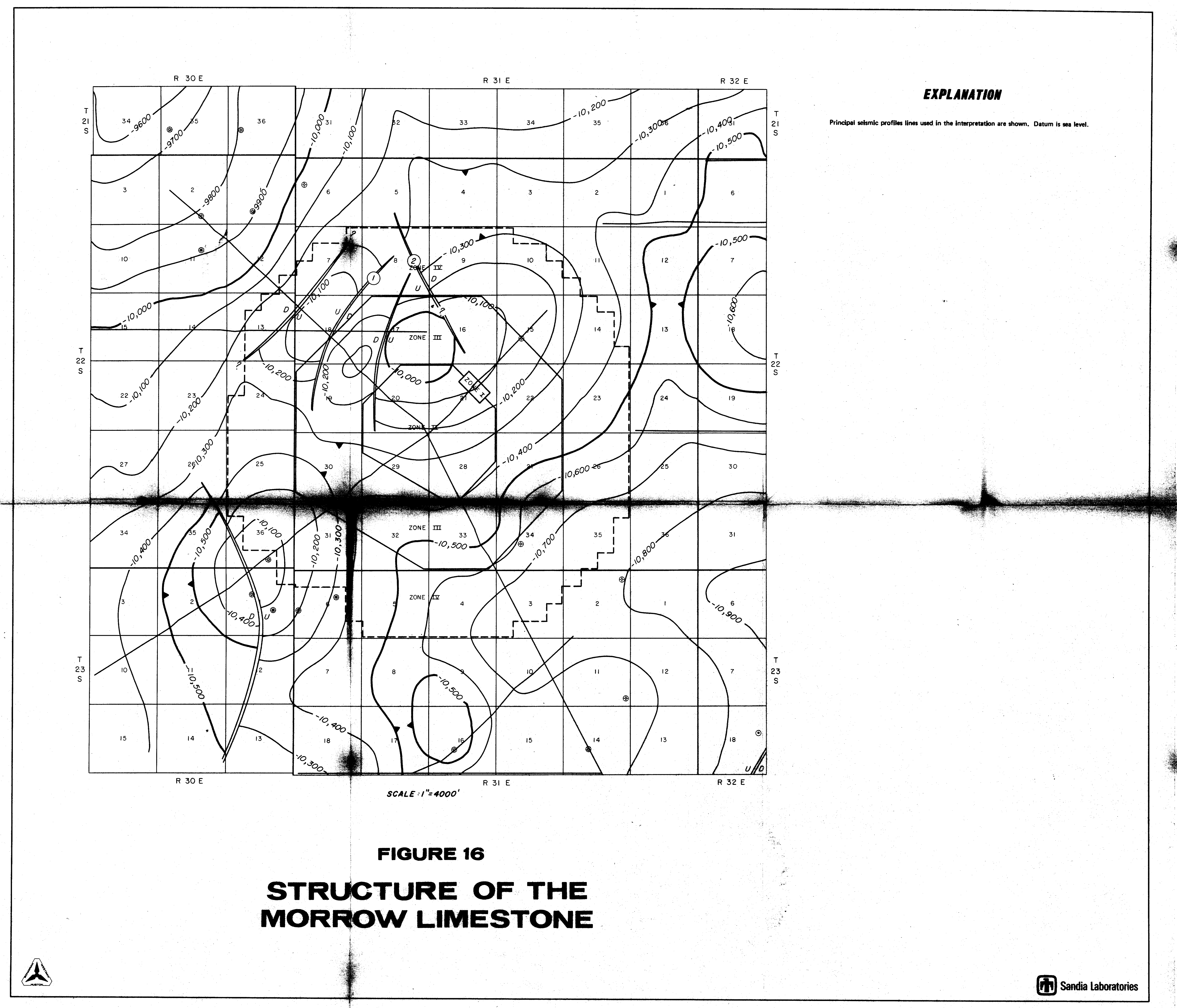




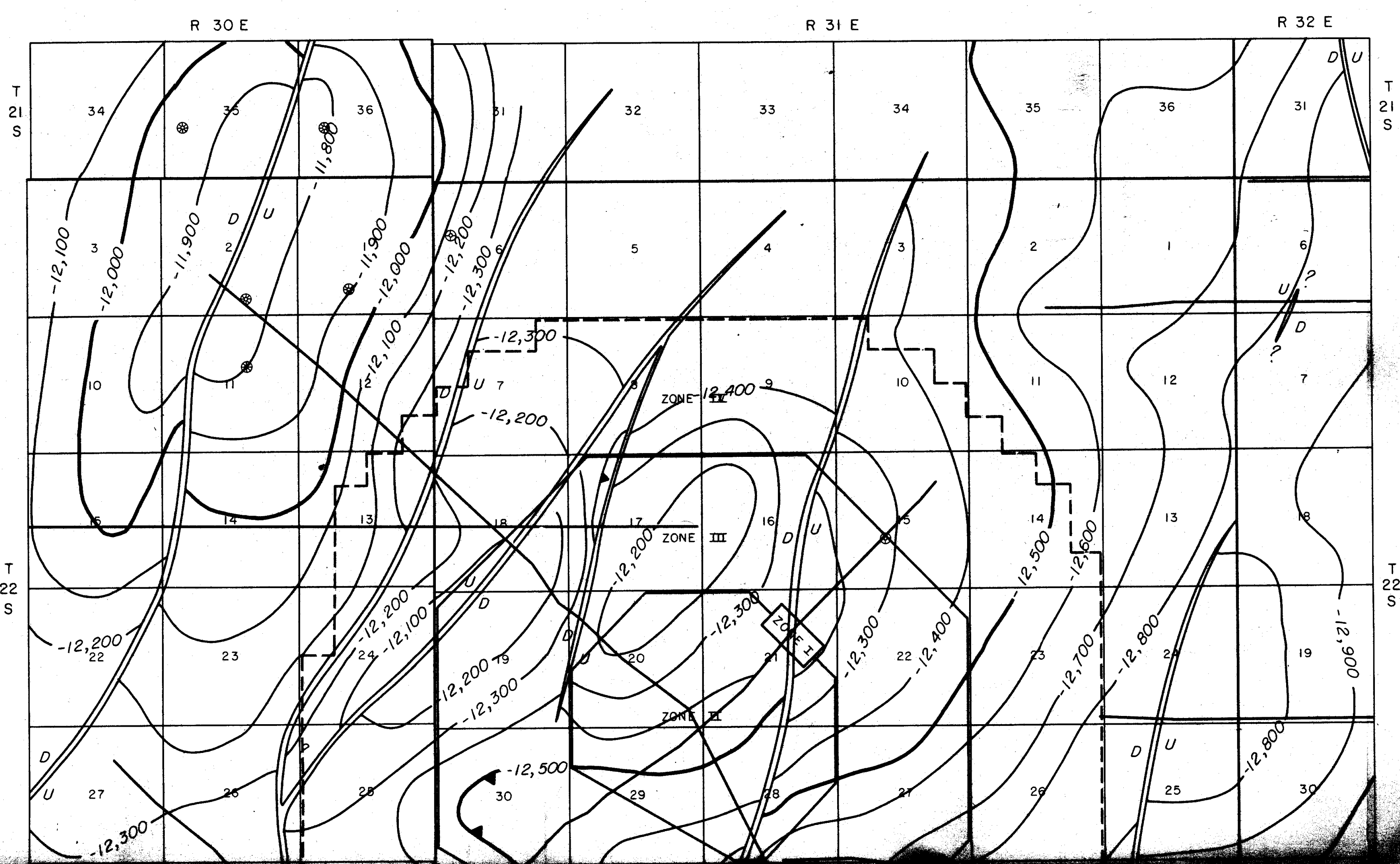

EXPLAMATION

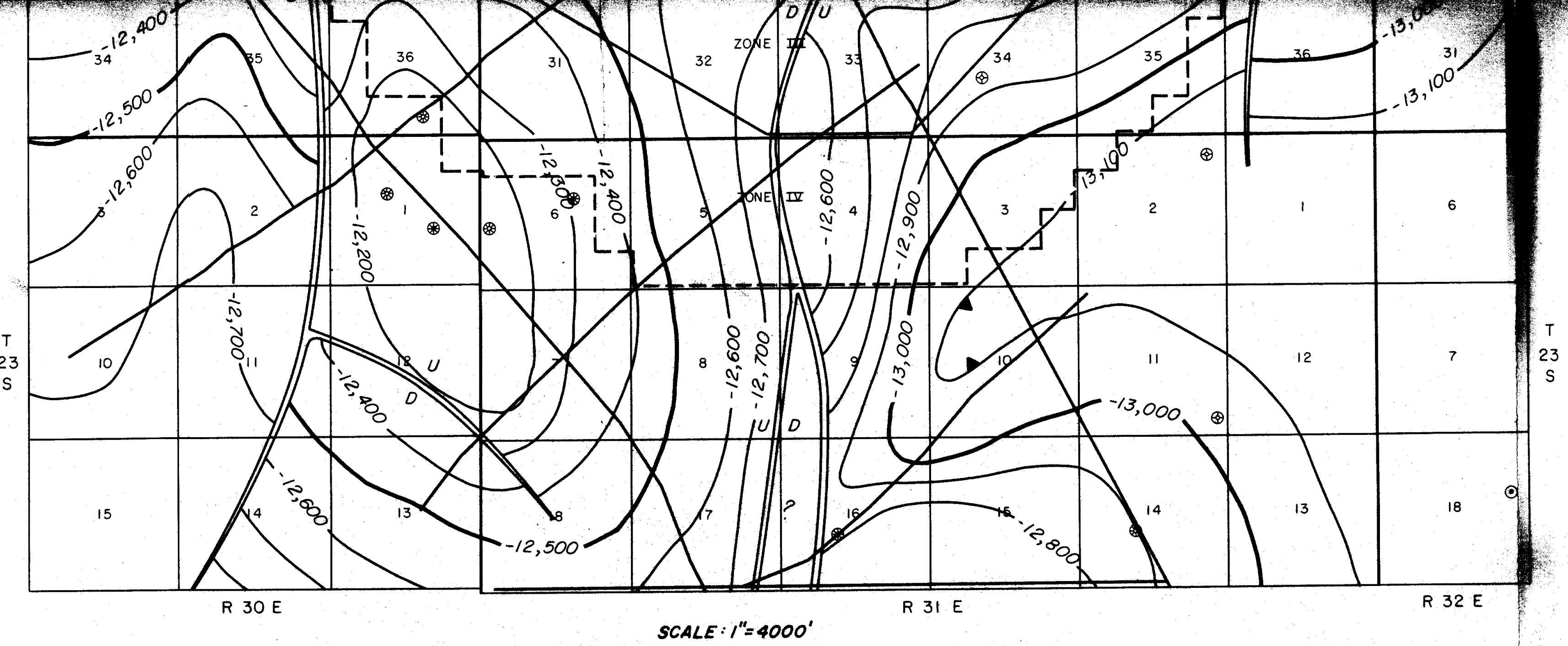

FIGURE 17

STRUCTURE OF A DEVONIAN HORIZON 


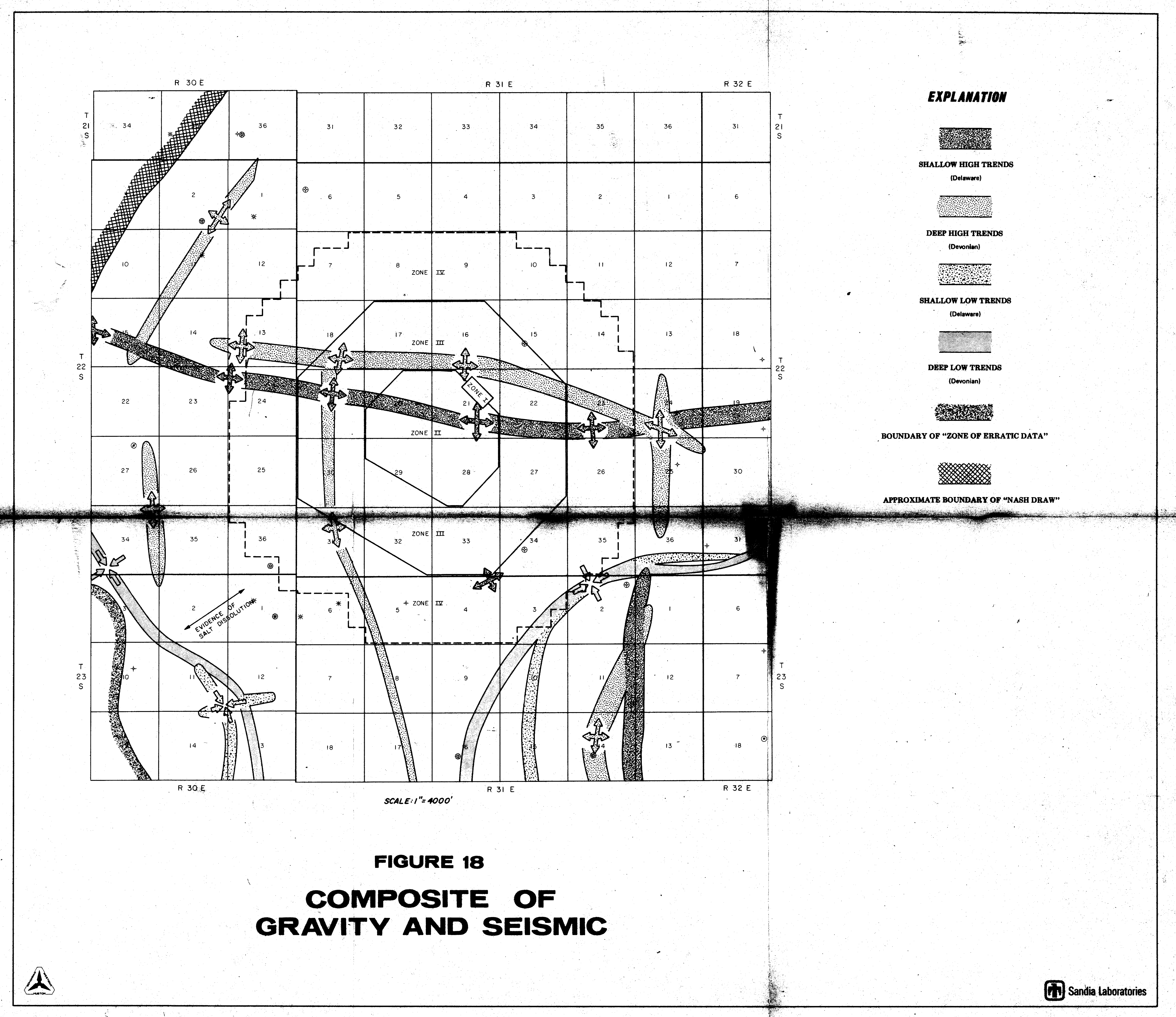




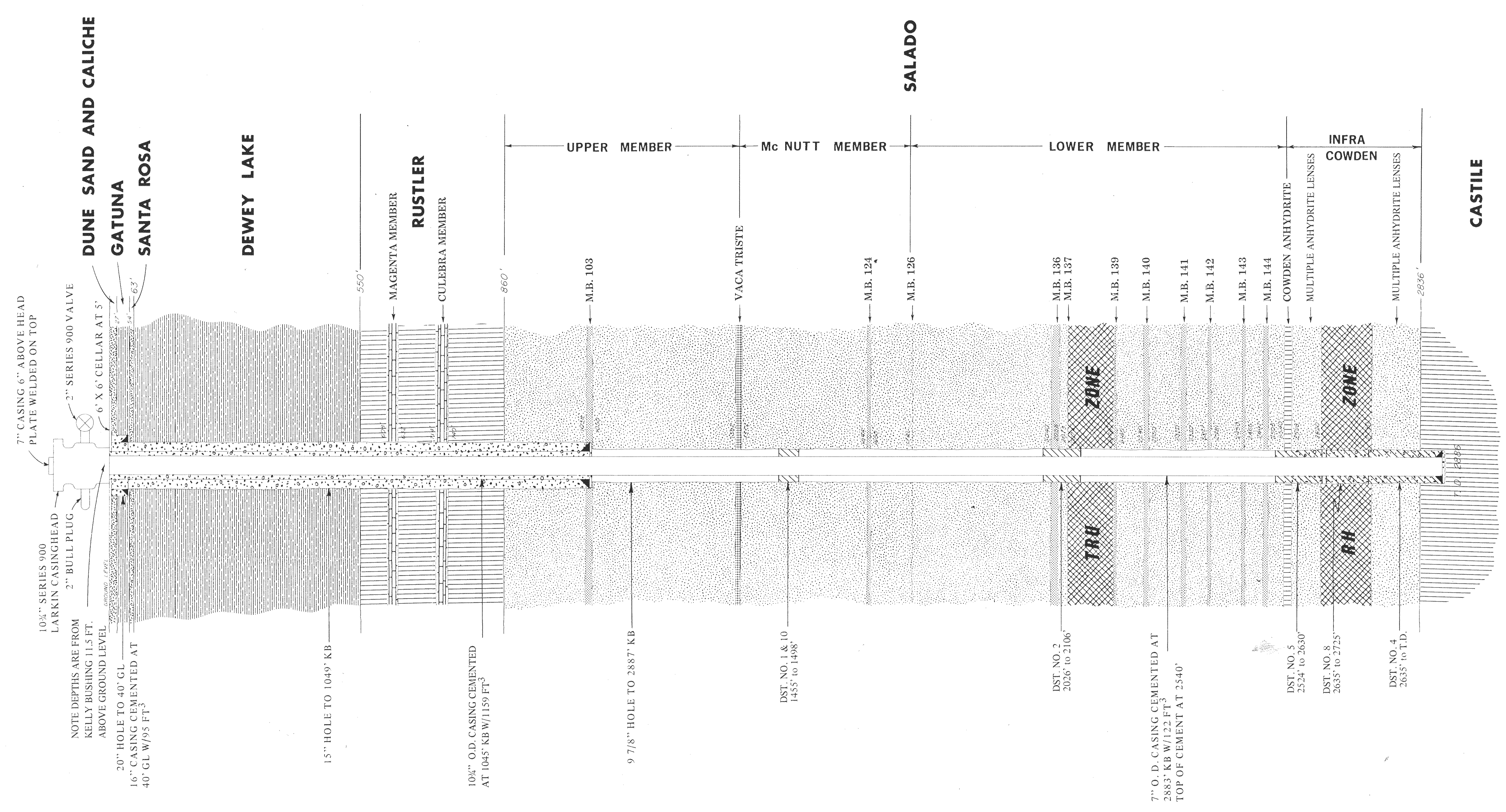

FIGURE 19

ERDA NO. 9 SCHEMATIC DIAGRAM 


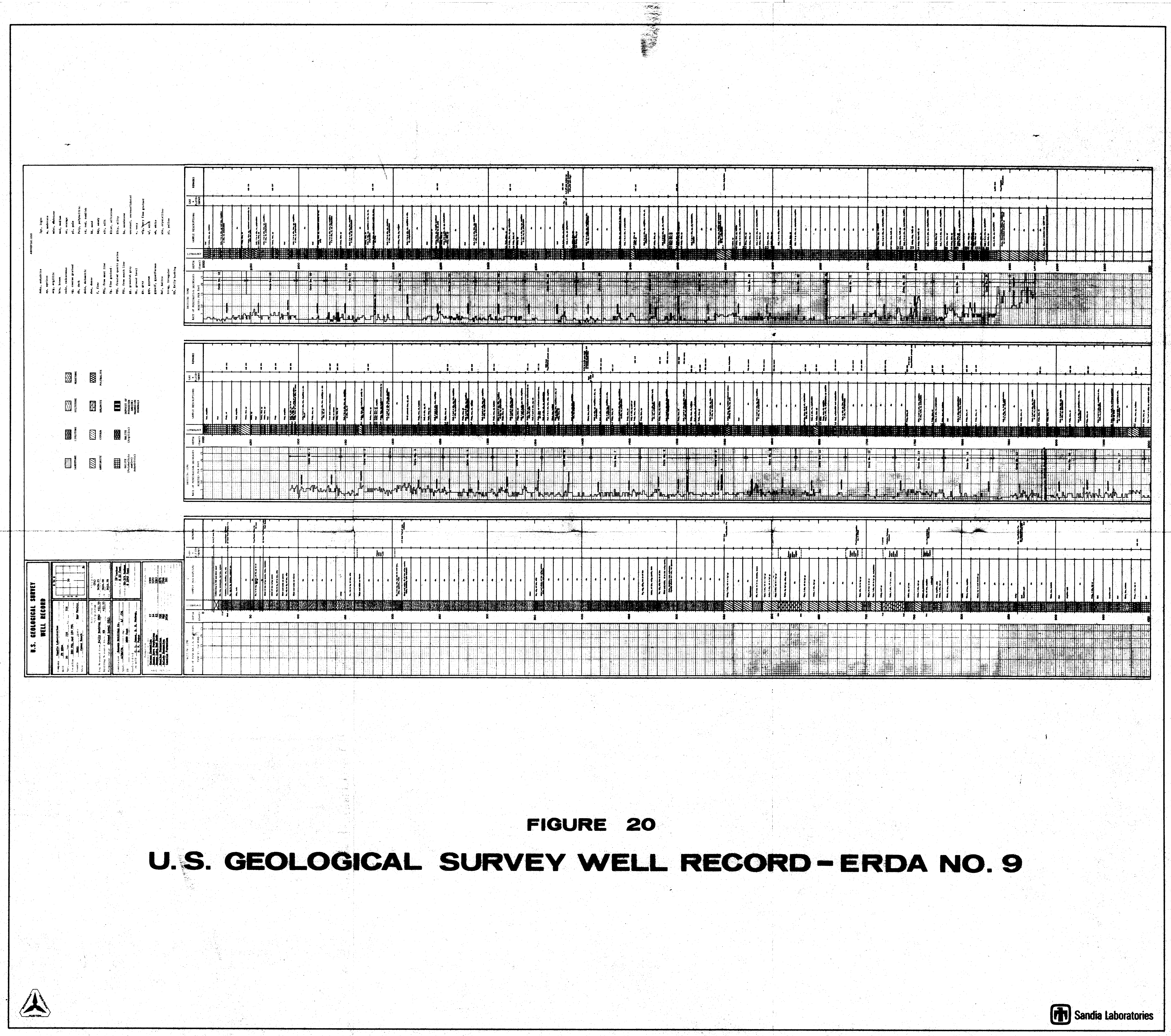




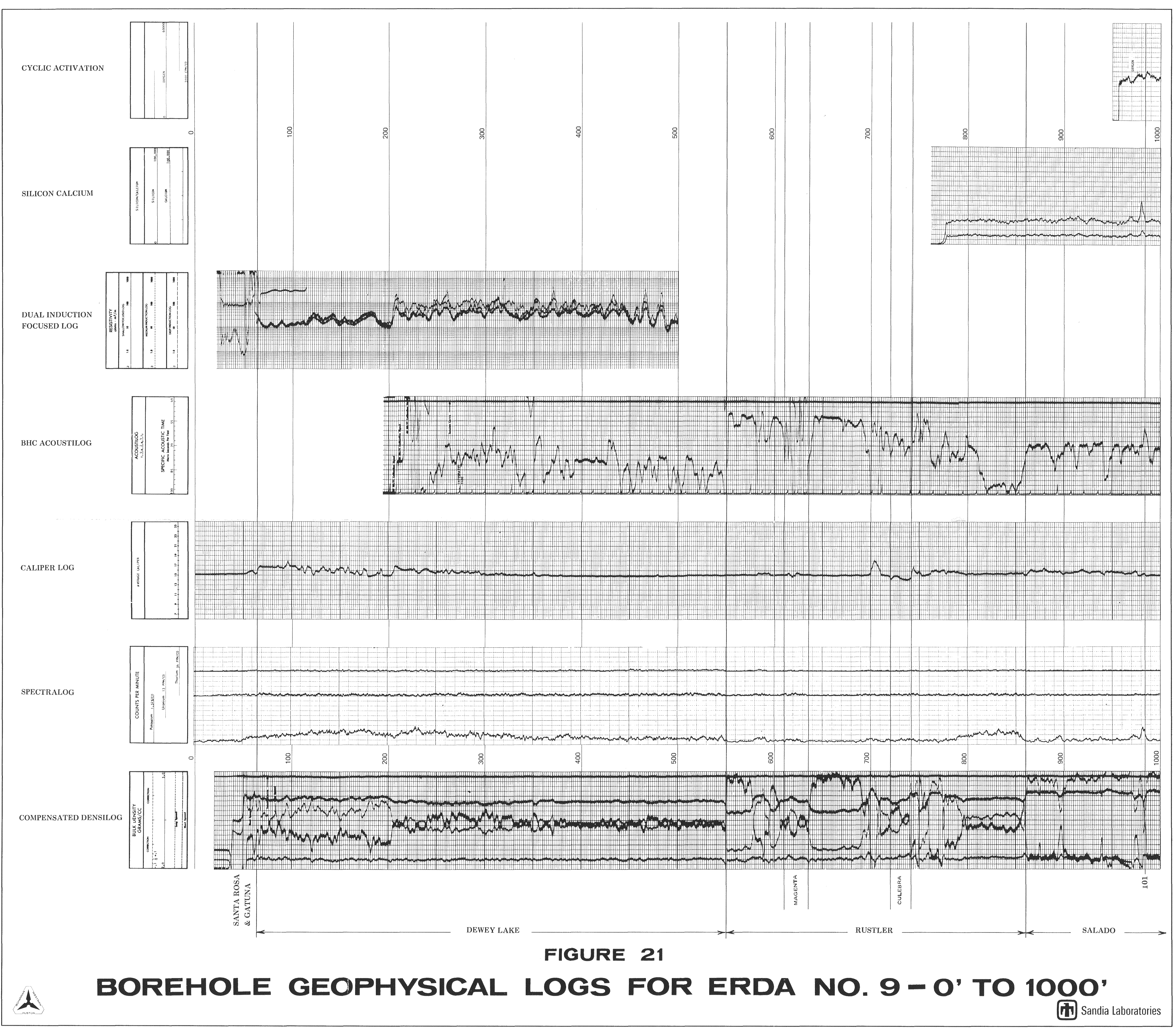




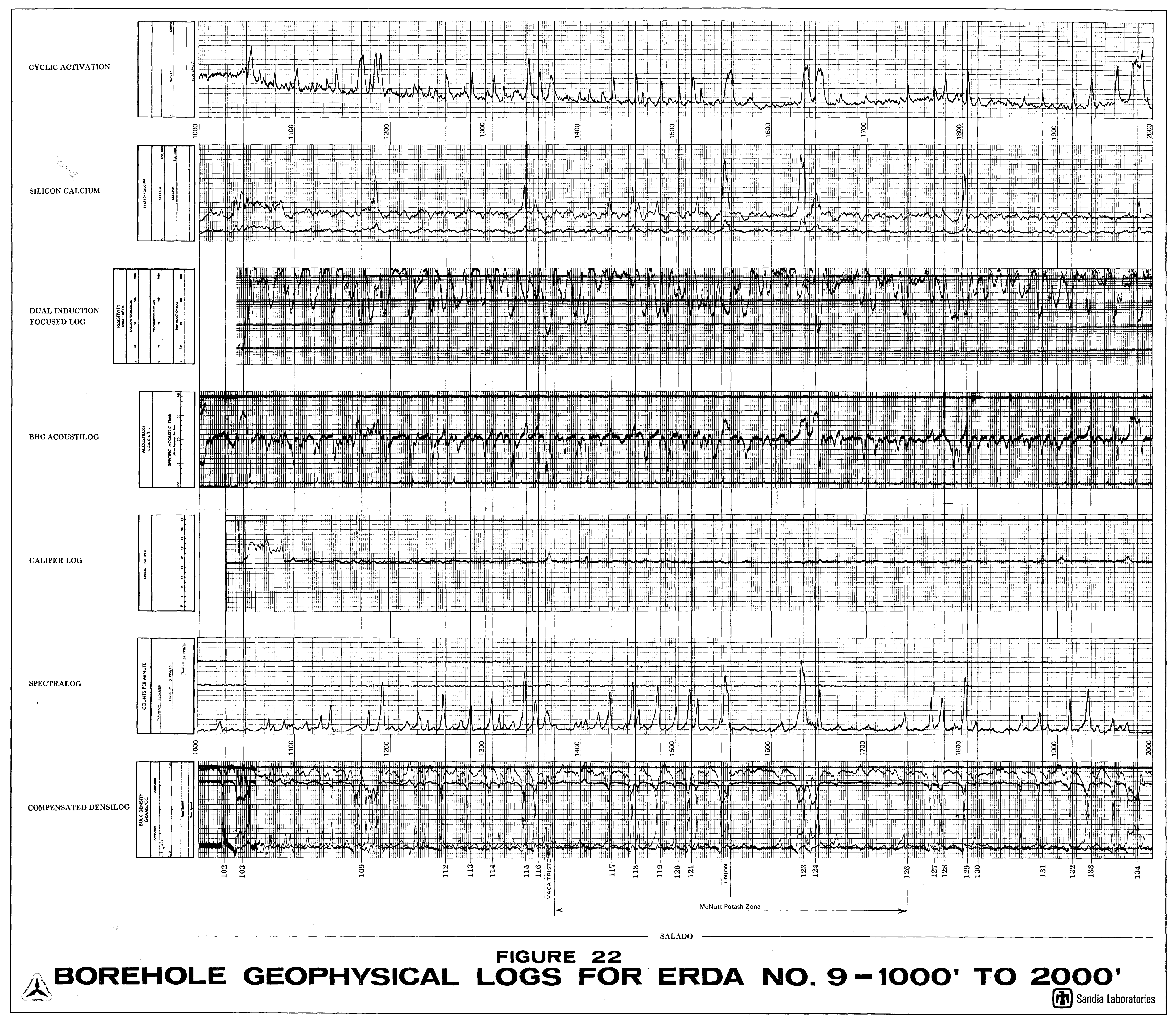




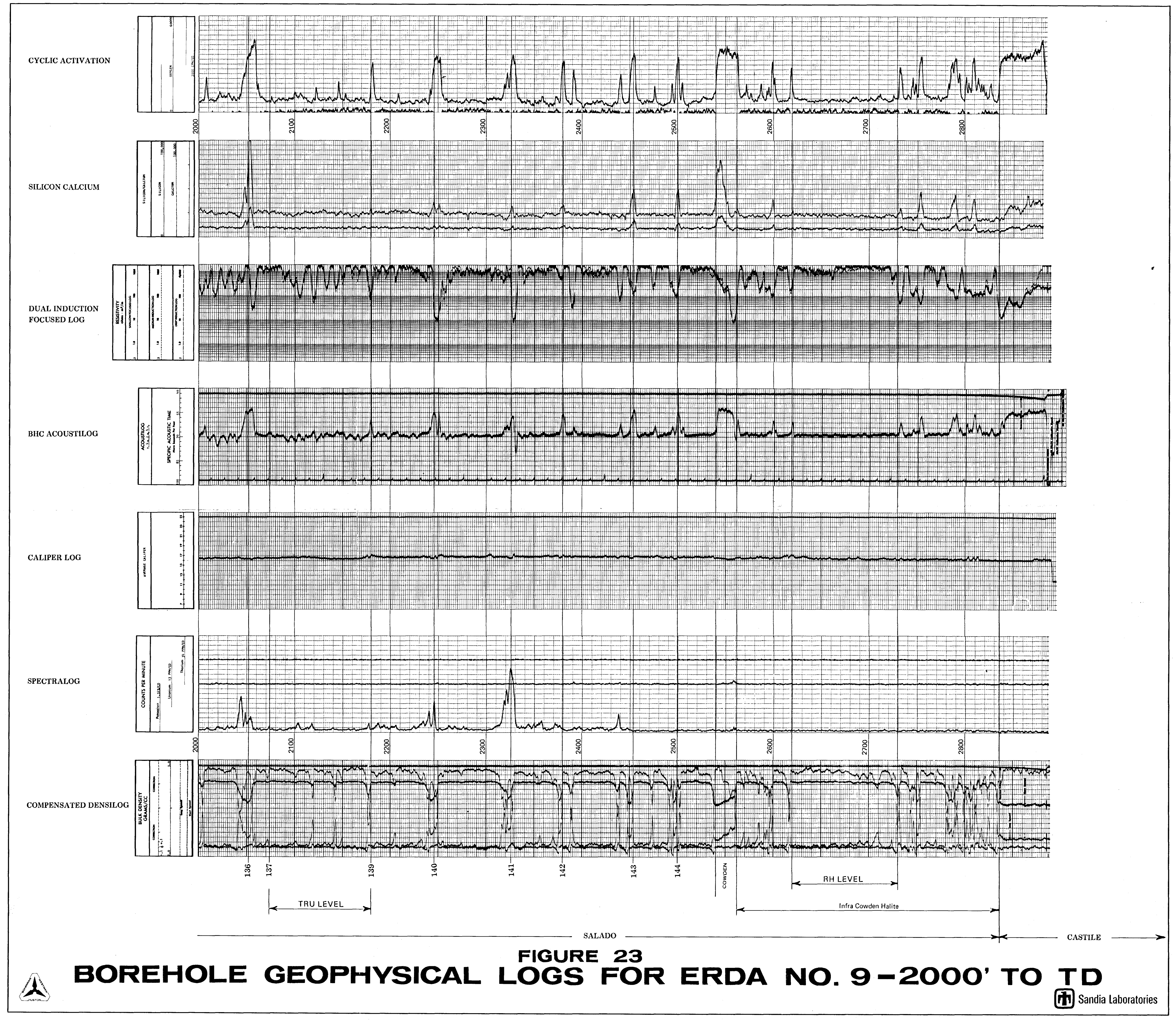




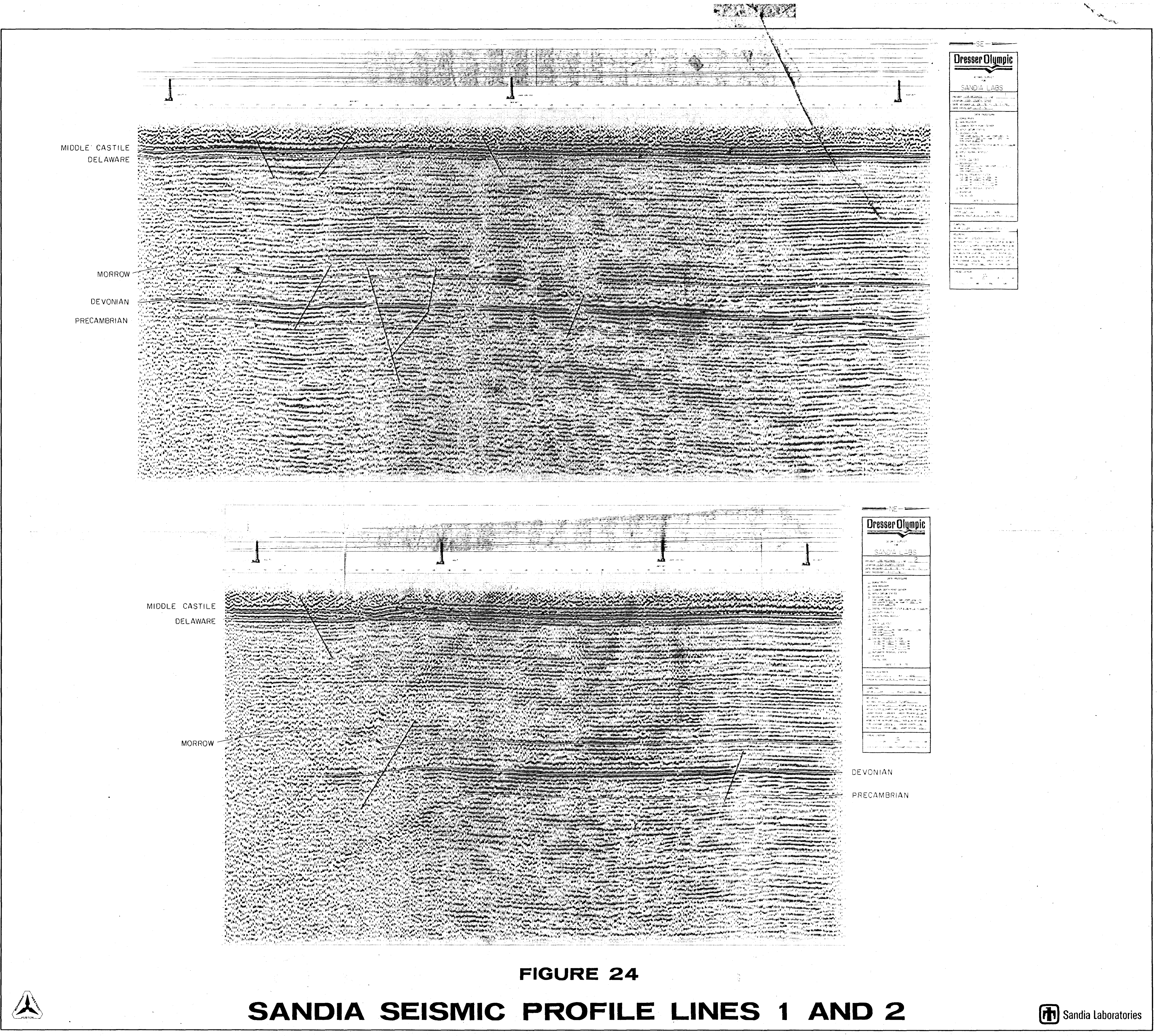



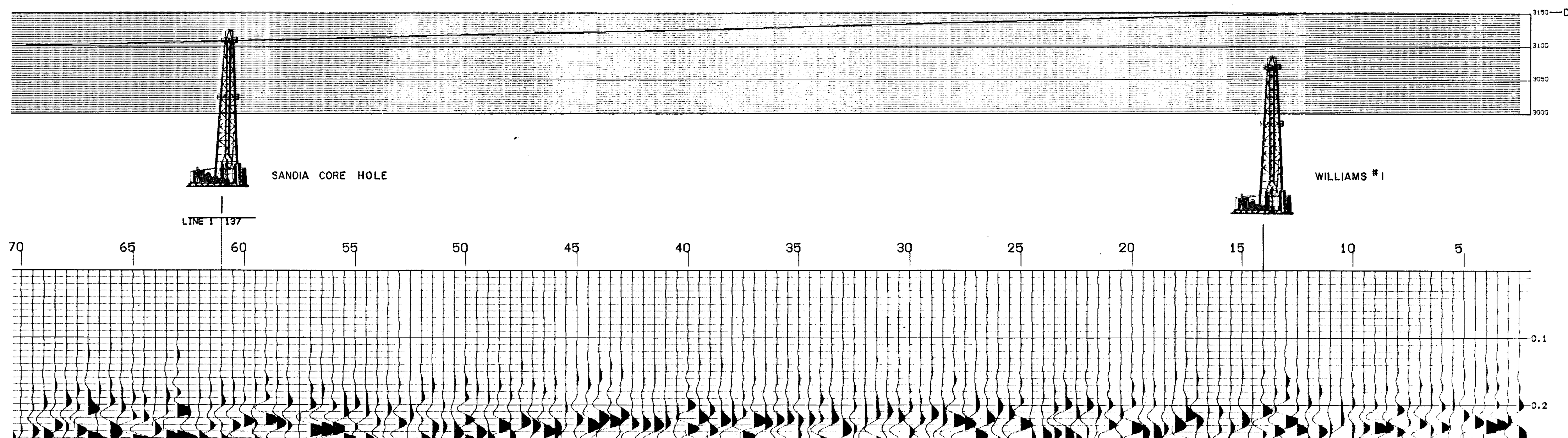

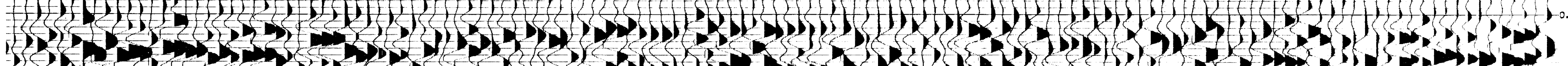

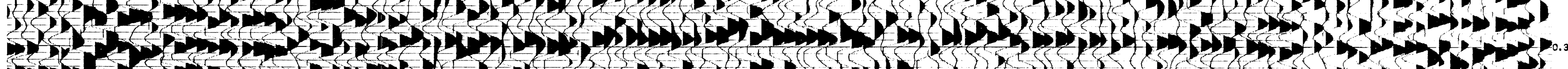

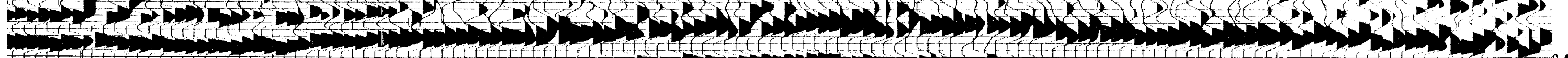
47 (1)

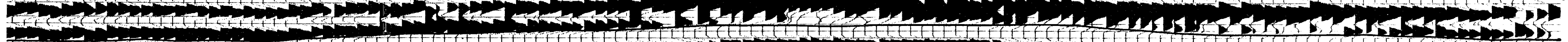

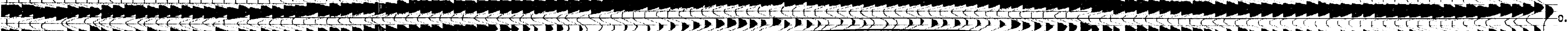

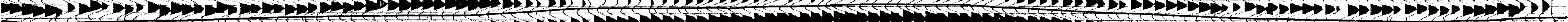

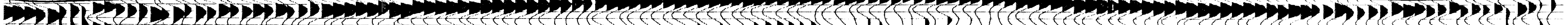

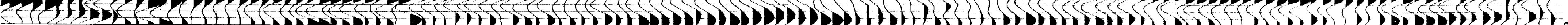
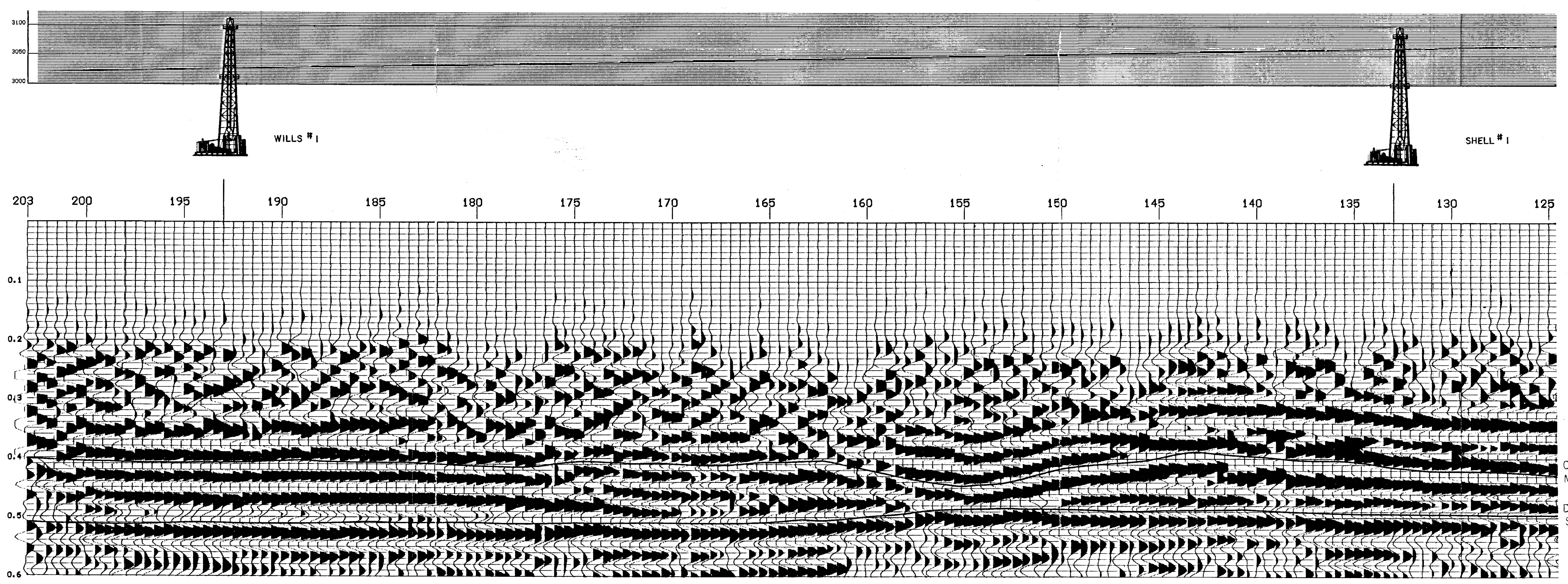

STATIONS 125 TO 203

FIGURE 25

A DETAILS OF TWO ANOMALIES ALONG SEISMIC PROFILE LINE 2 


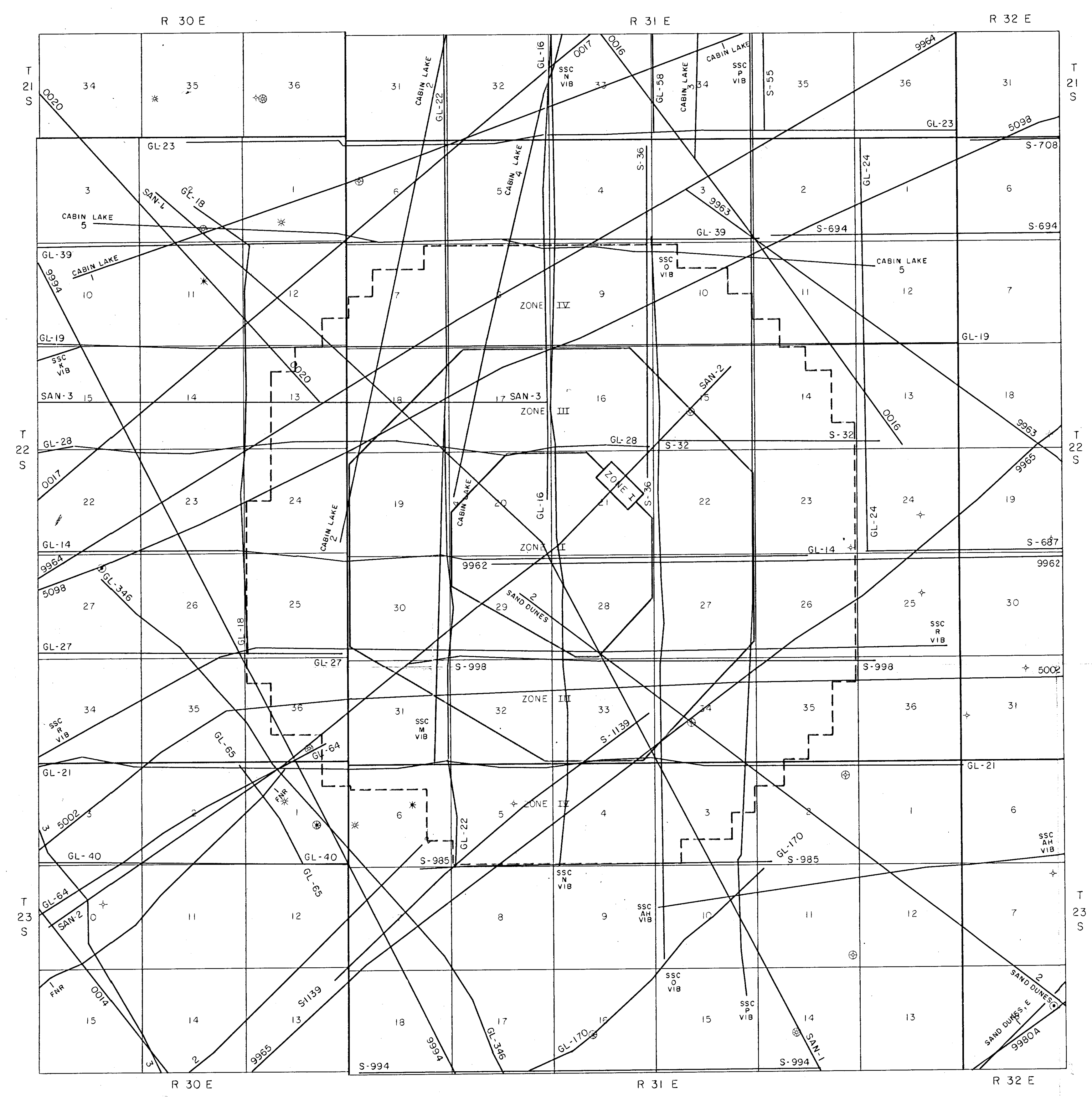

EXPLANATION

All lines Only Sandia Lines 1, 2, and 3 are available for inspection.

FIGURE 26

COMPILATION OF

SEISMIC LINES 


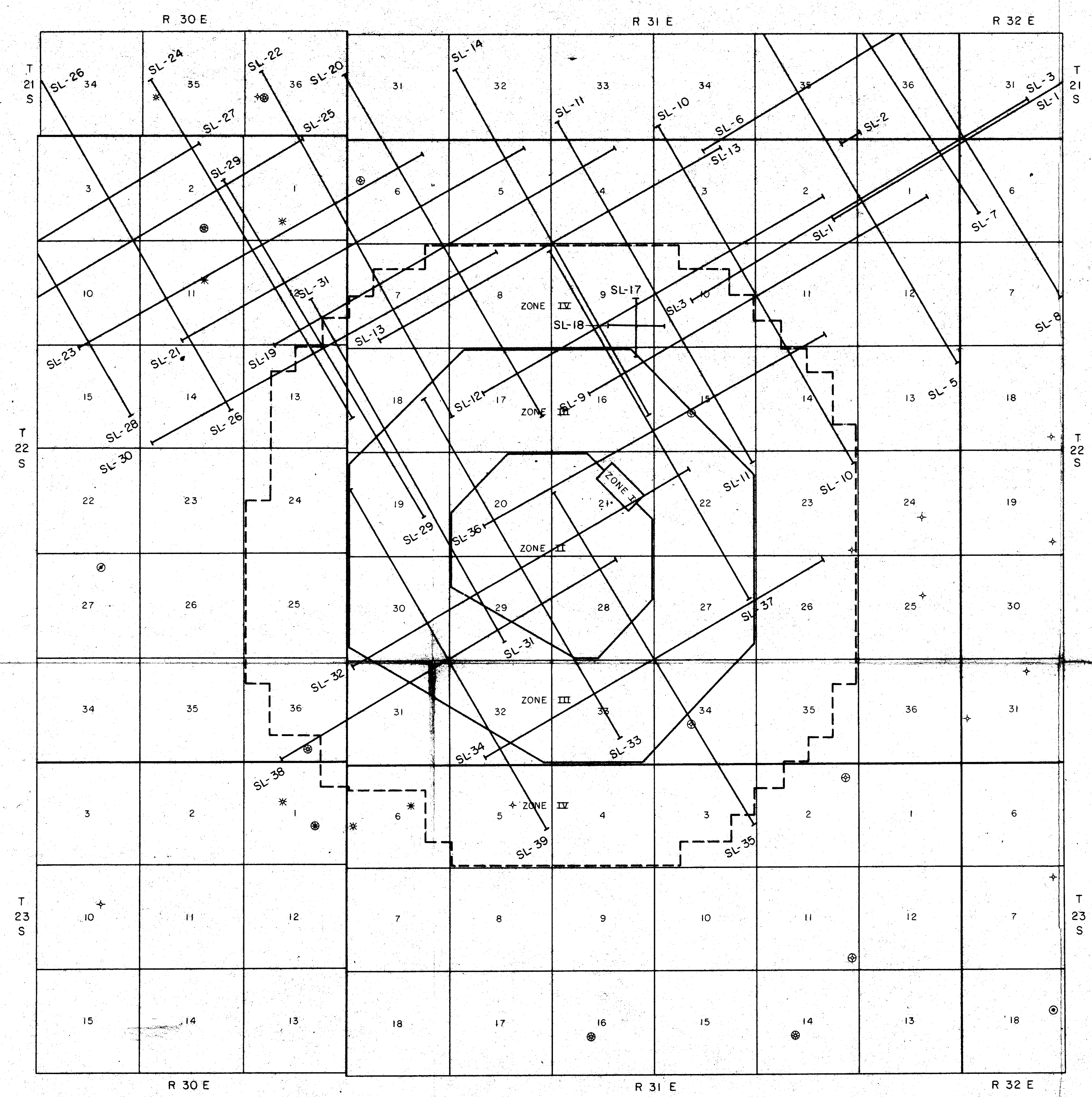

FIGURE 27

LOCATION OF

SCHLUMBERGER EXPANSION ARRAYS 


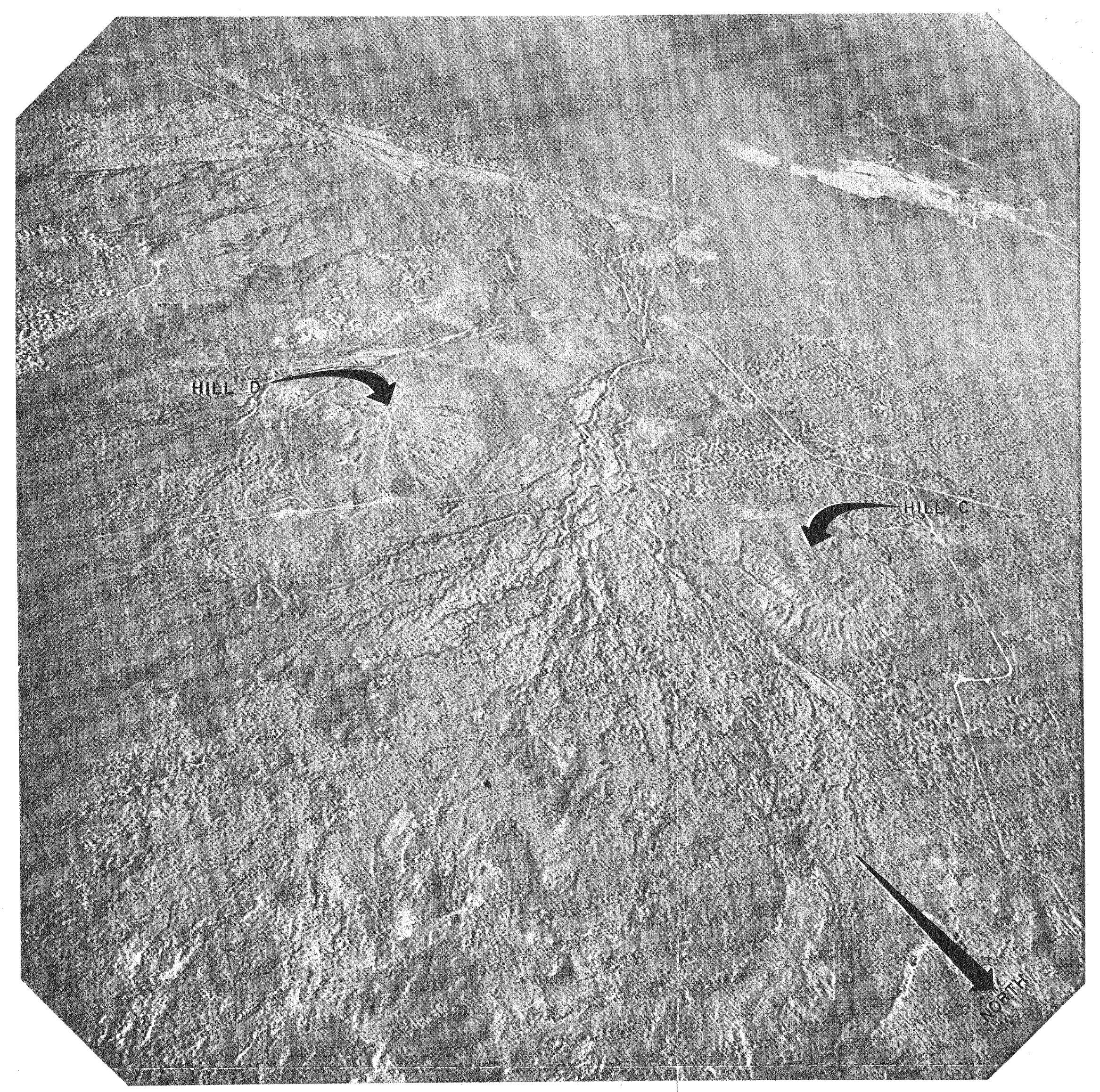

HILL C AND D

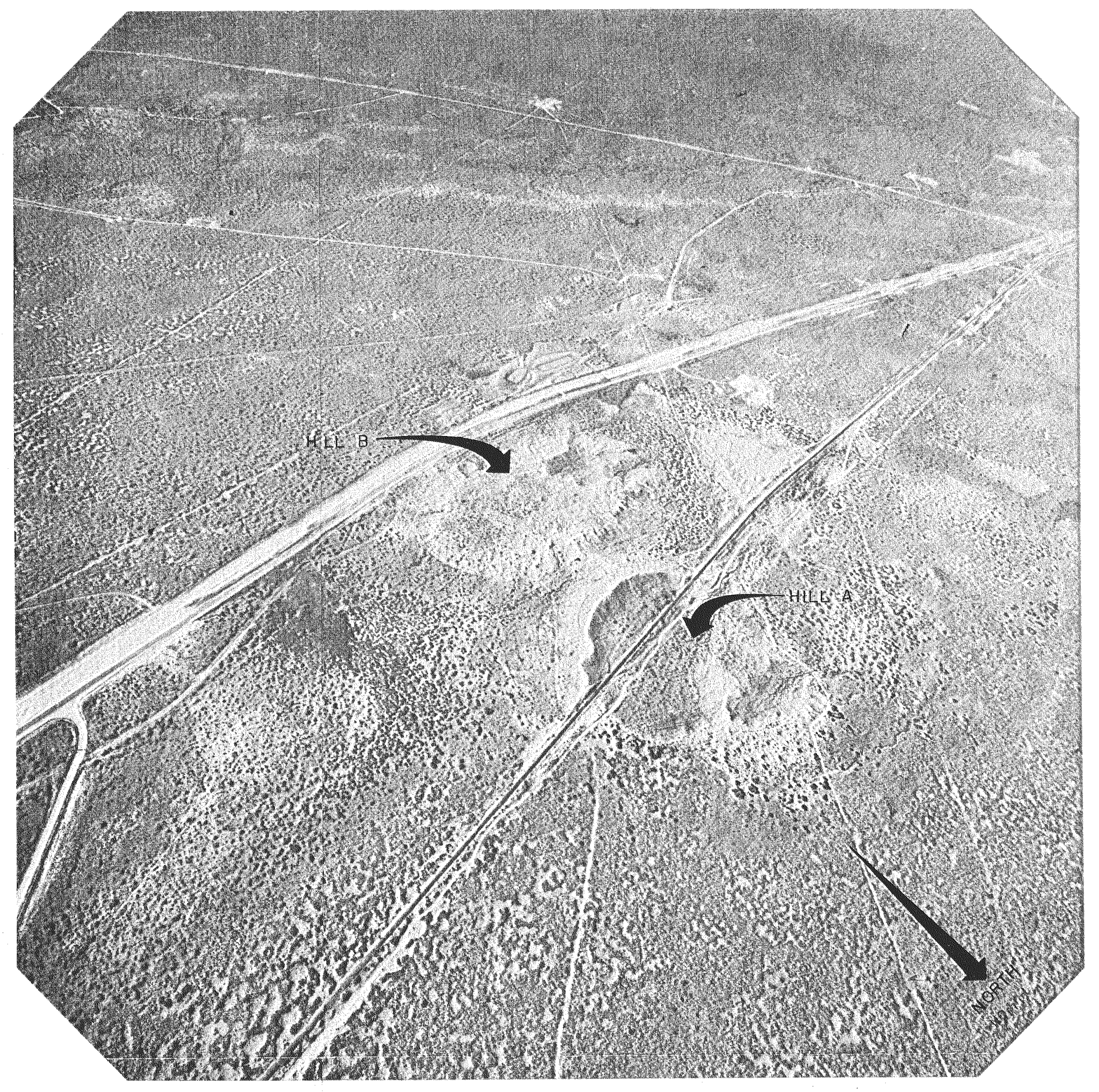

HILL A AND B

beds capped by caliche Blocks of Santa Rosa are present inside crater. Hill B is caliche capped, but parti

possed.

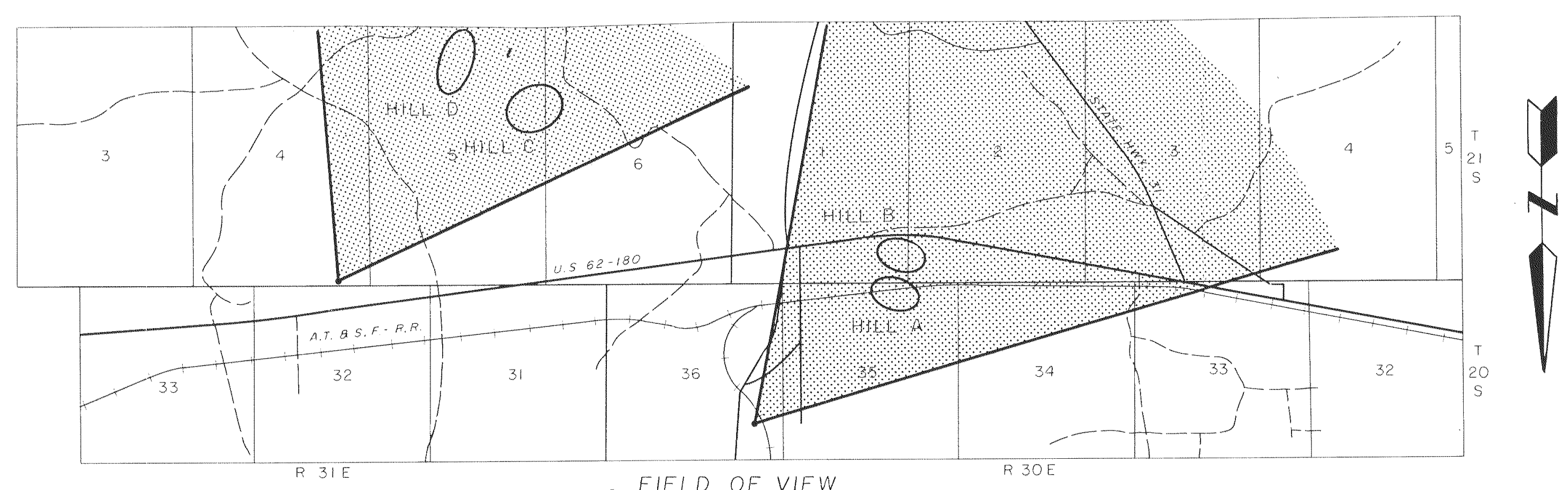

FIGURE 28

INCLINED AIR PHOTOS OF BRECCIA PIPES 


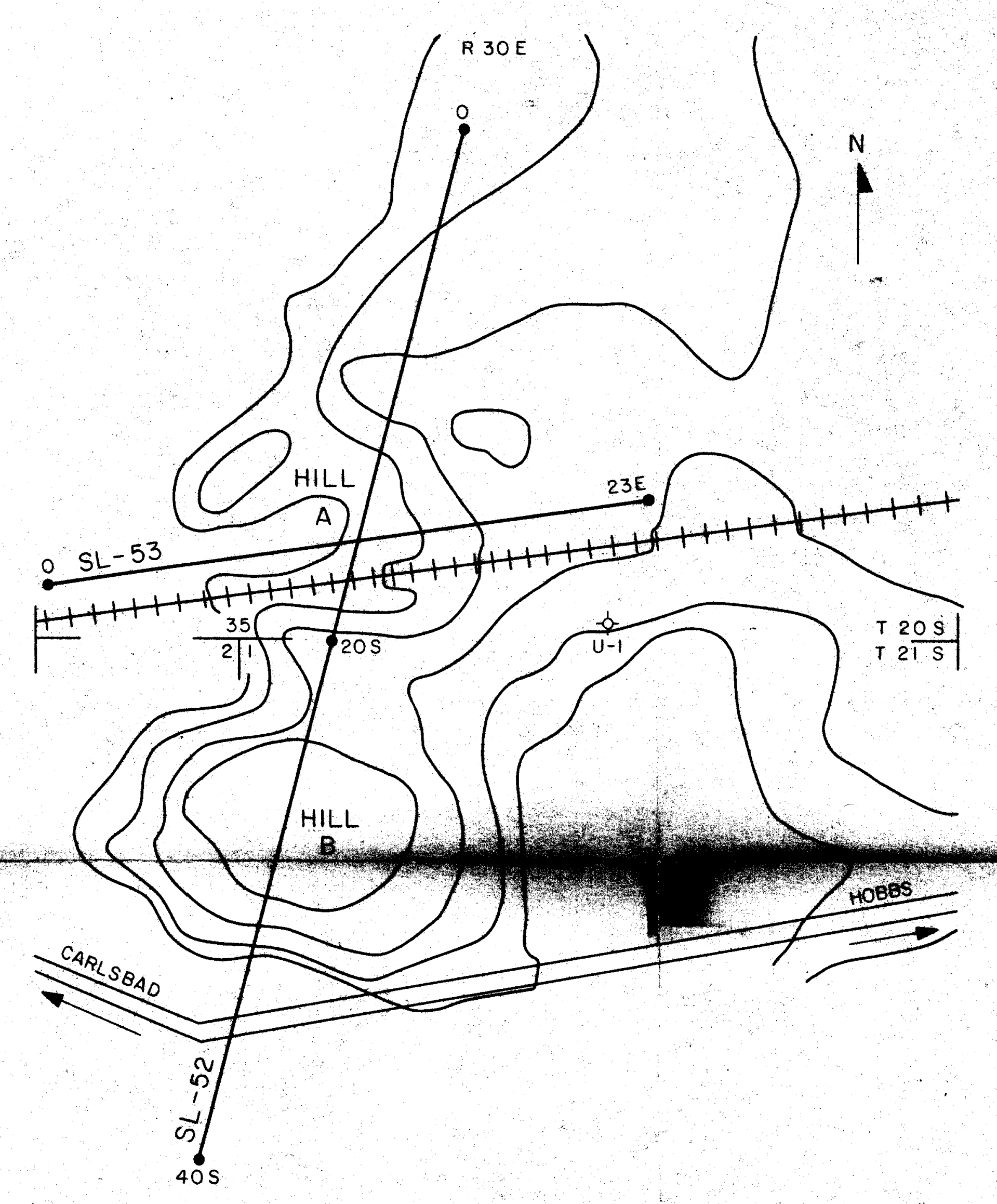

NOTE: IDEALIZED CONTOURS

RESISTVITY PROFLES
HILL A Q B AREA
EDDY COUNTY NEW MEXICO

LR29E SCALE: $1: 6000$ DATE: $12-22-76$ REF : SL IE

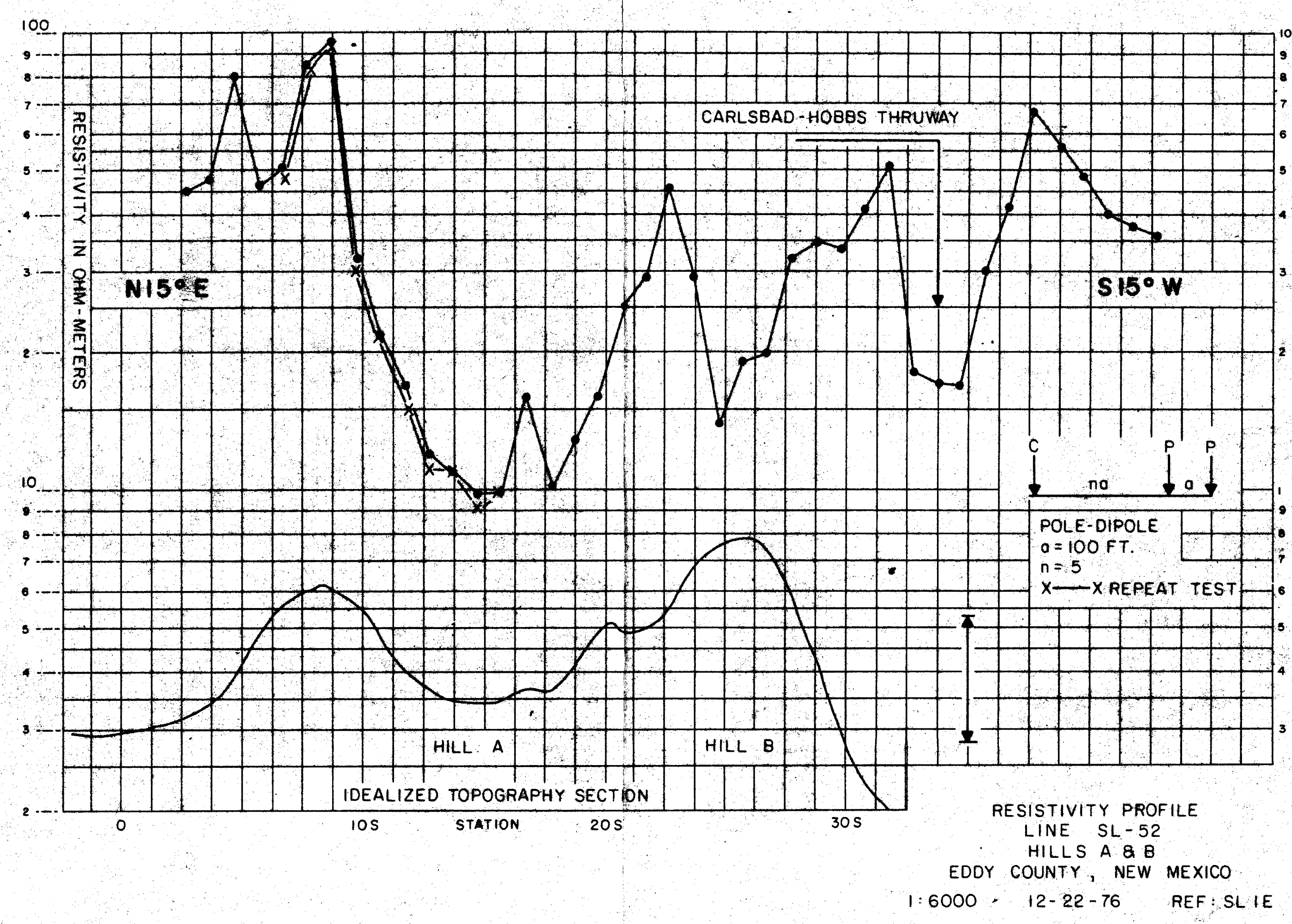

100

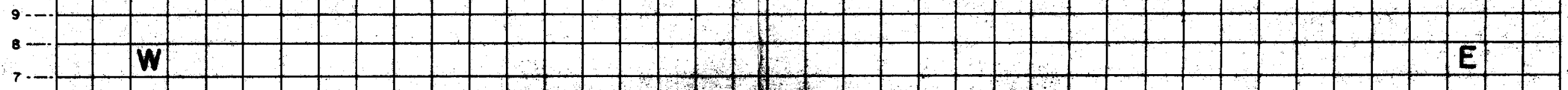

-. 1 -

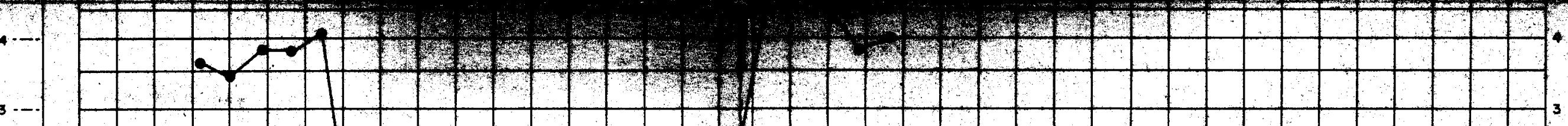

FIOURE 20

ELECTRIOAL SURVEY RESULTS OVER A BRECCIA PIPE (HILL A \& B) 


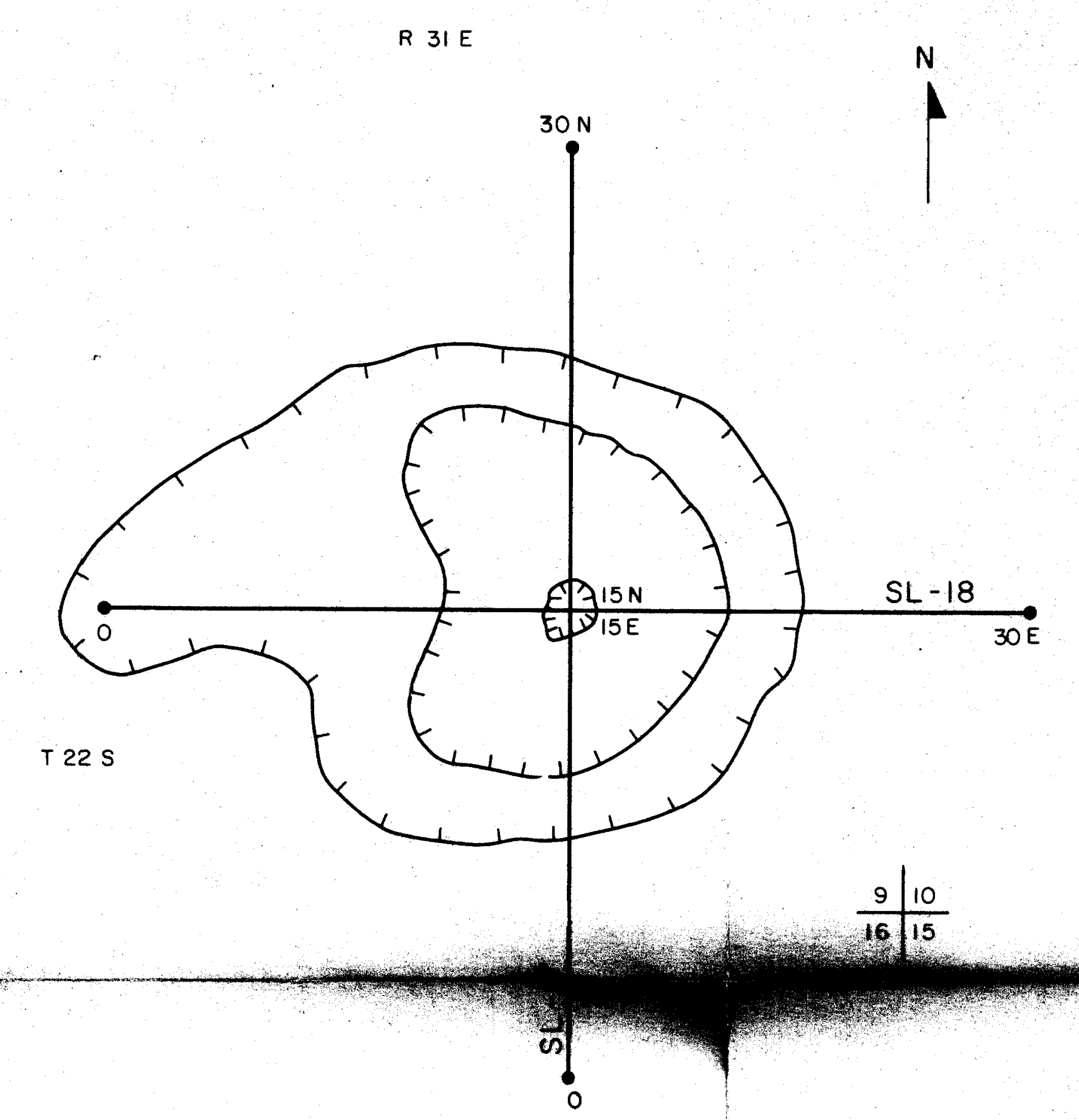

NOTE : IDEALIZED CONTOURS

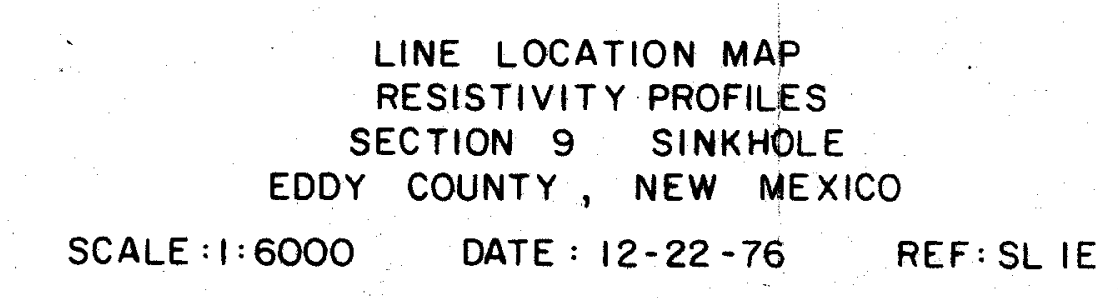

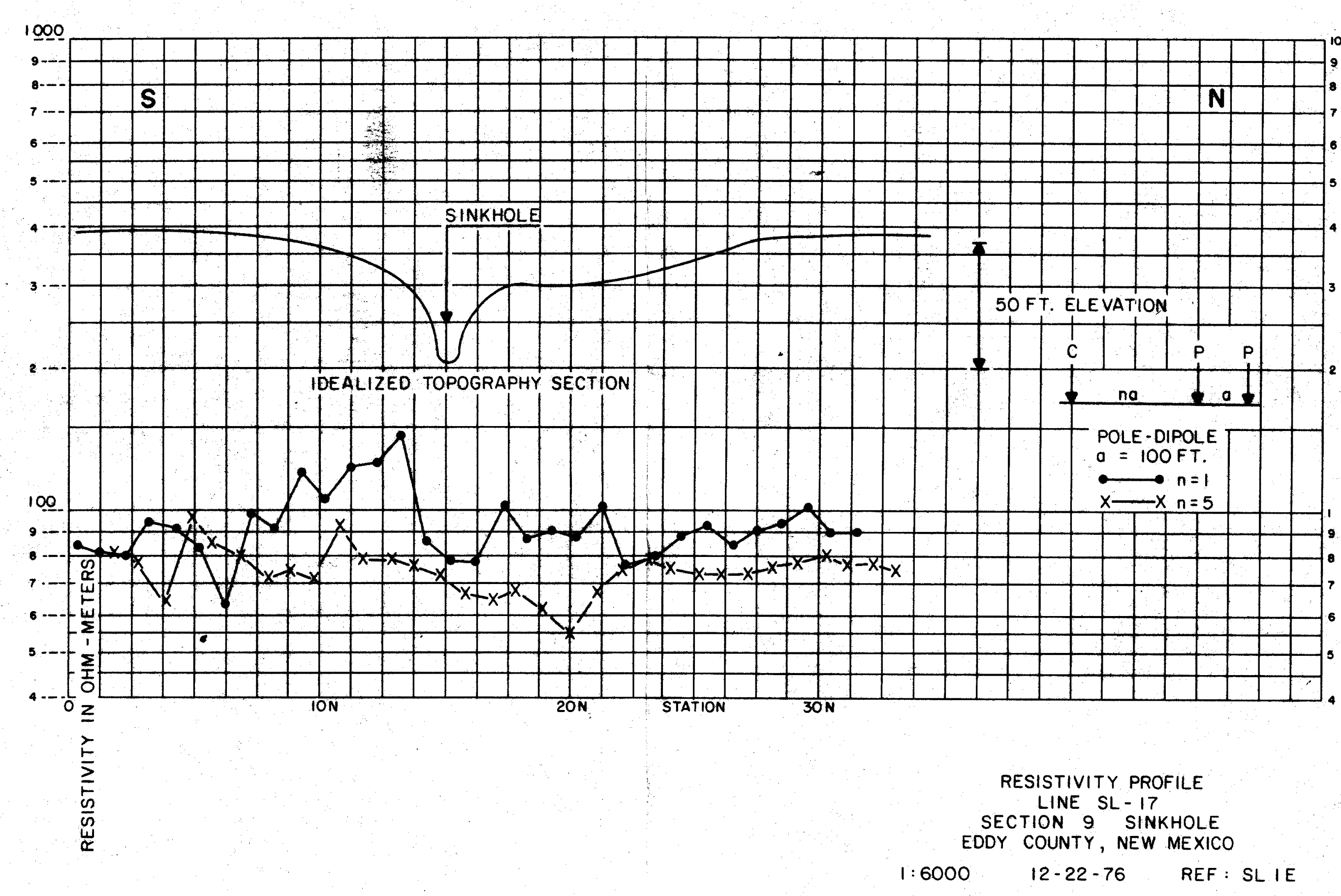

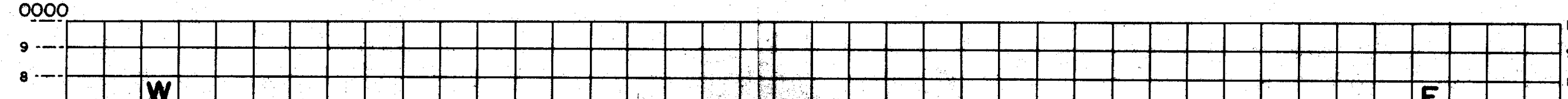

w

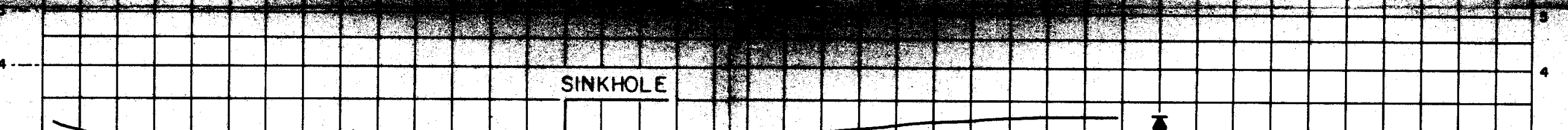

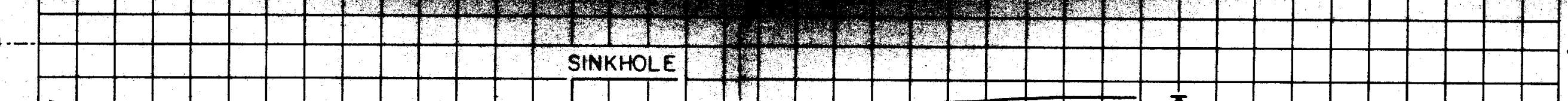

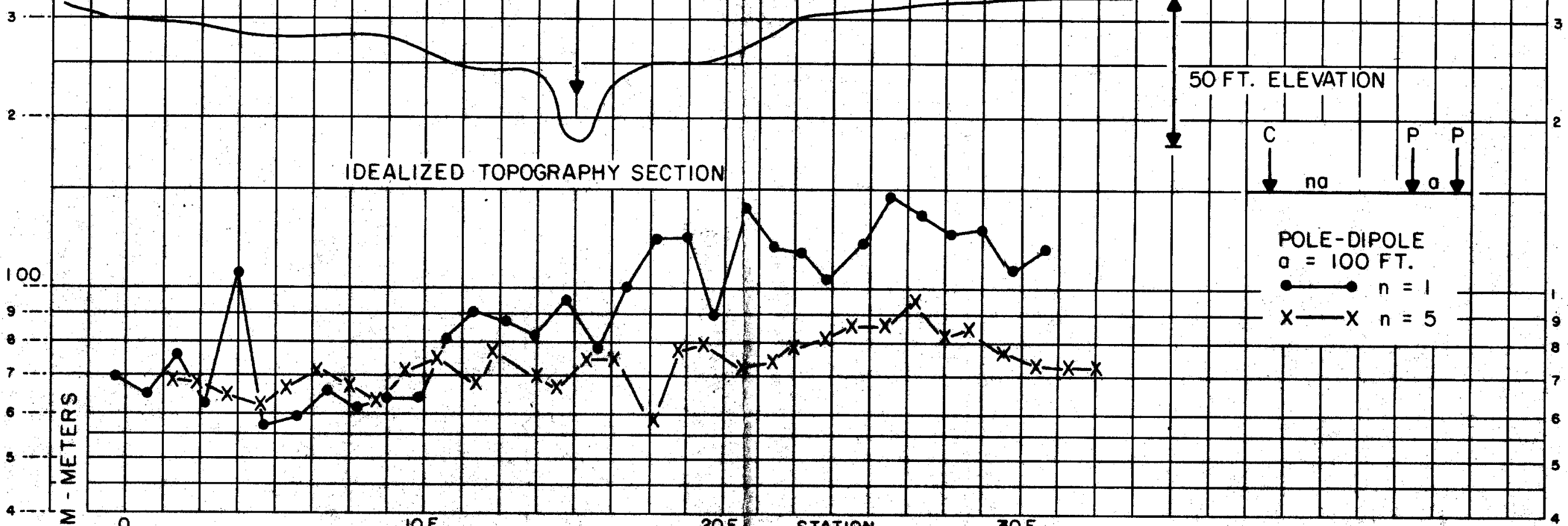

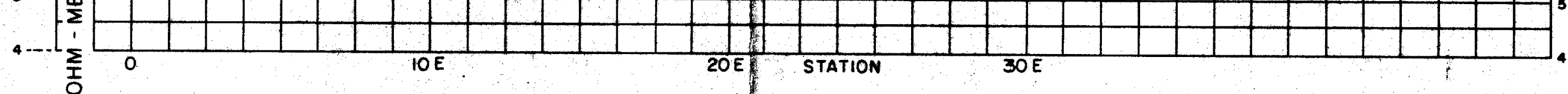

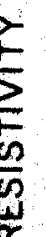

FIGURE 30

ELECTRICAL SURVEY RESULTS OVER A SHALLOW SINK HOLE IN SECTION 9 


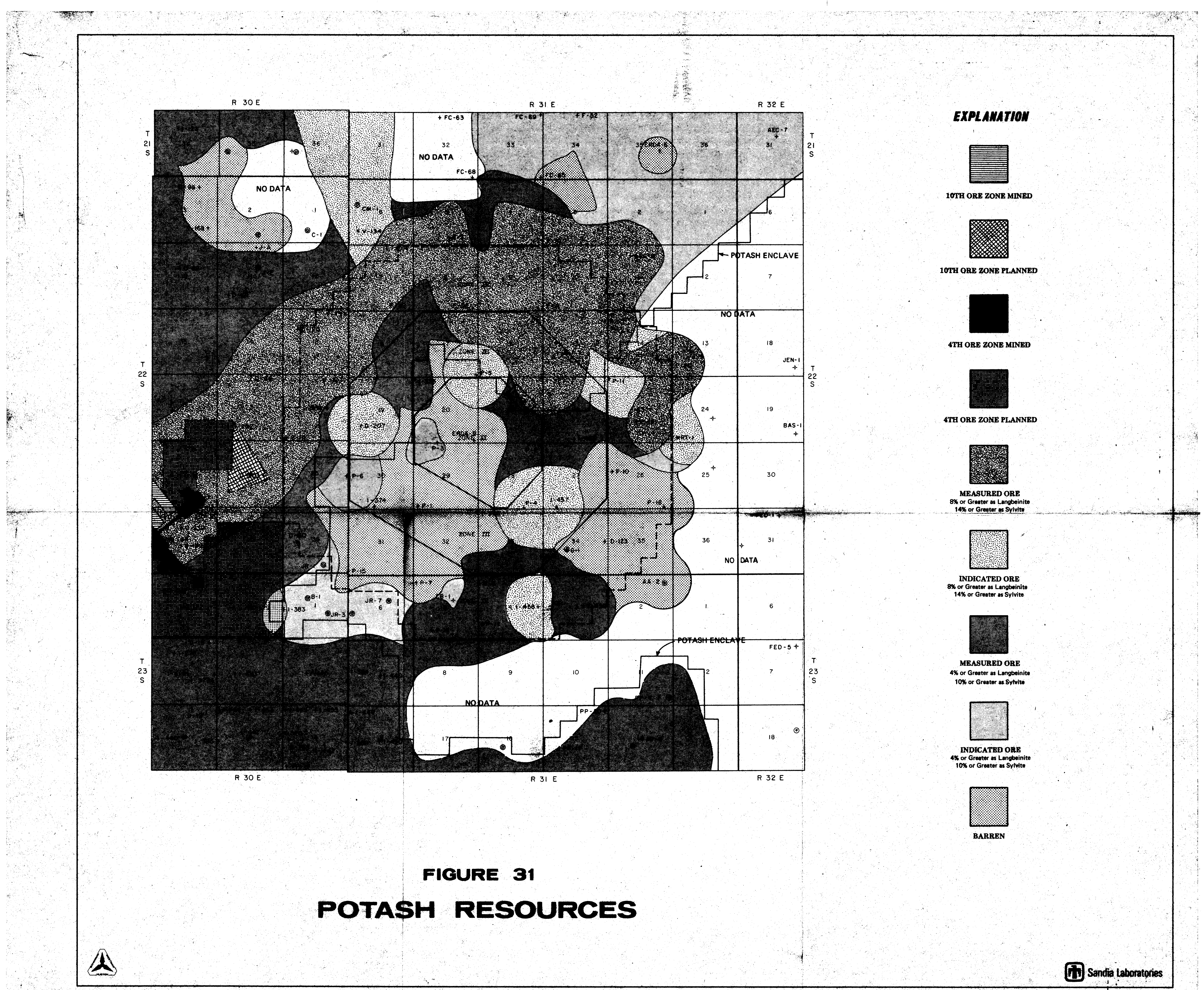




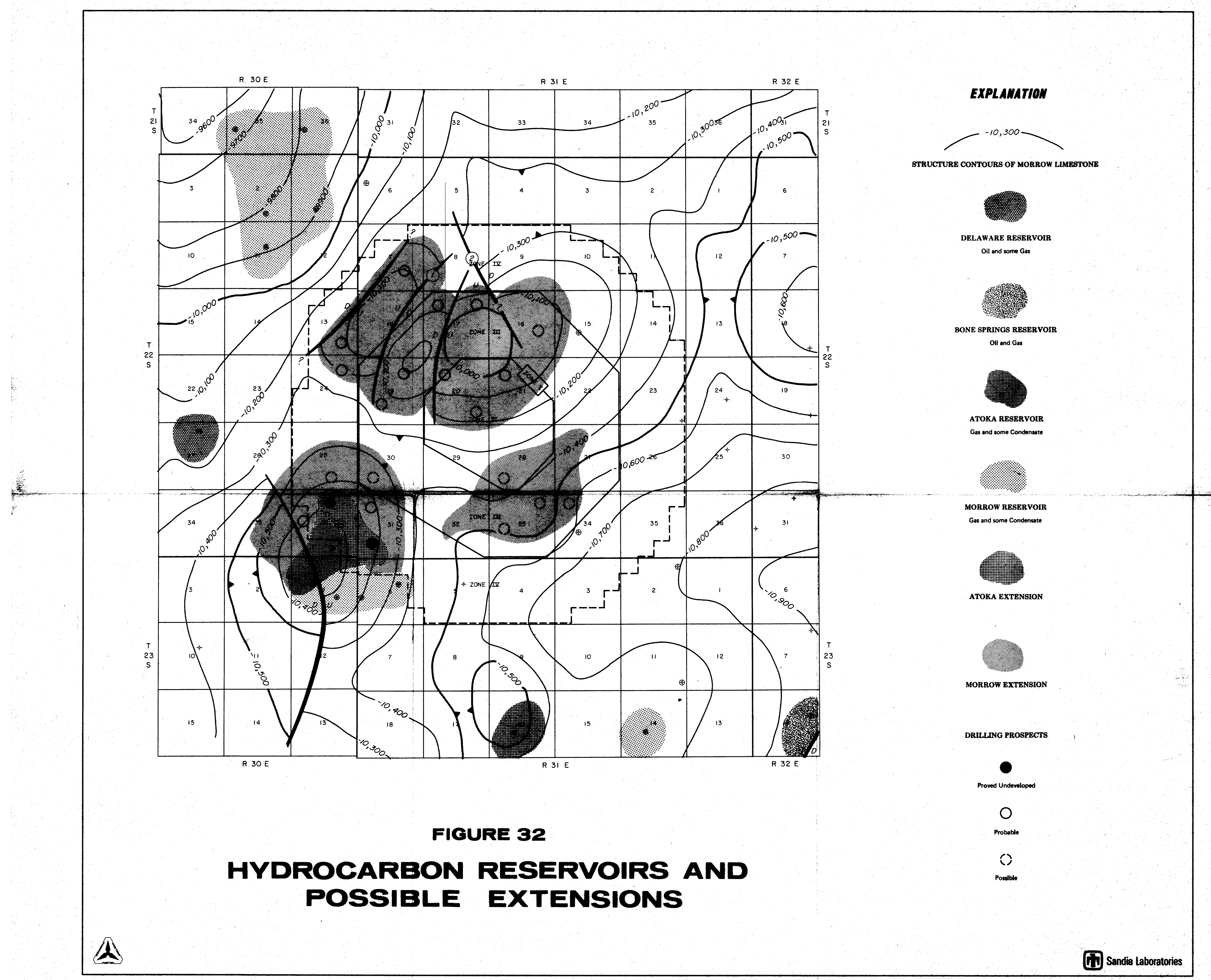




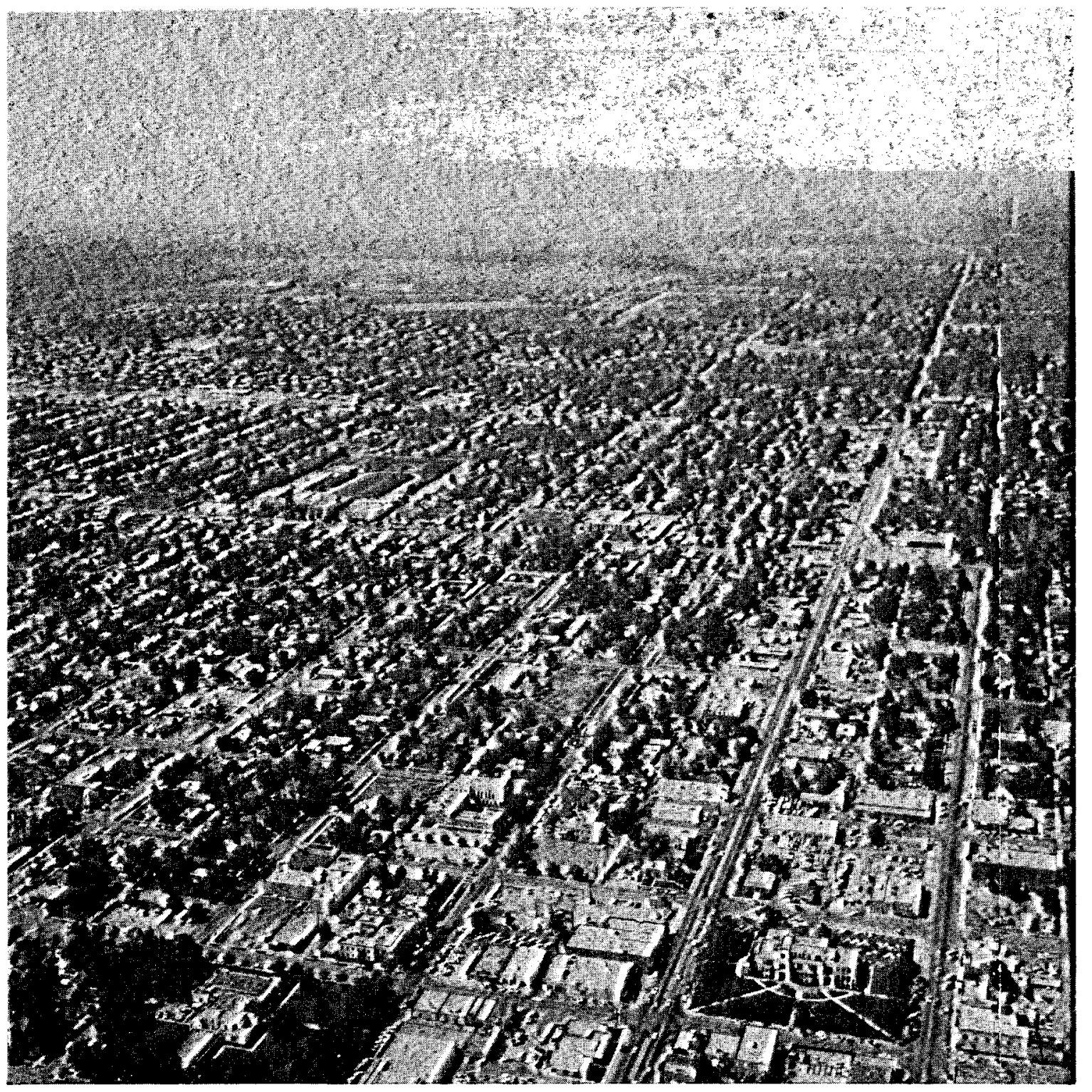

CITY OF CARLSBAD

View is to the north. County Court House in lower right.

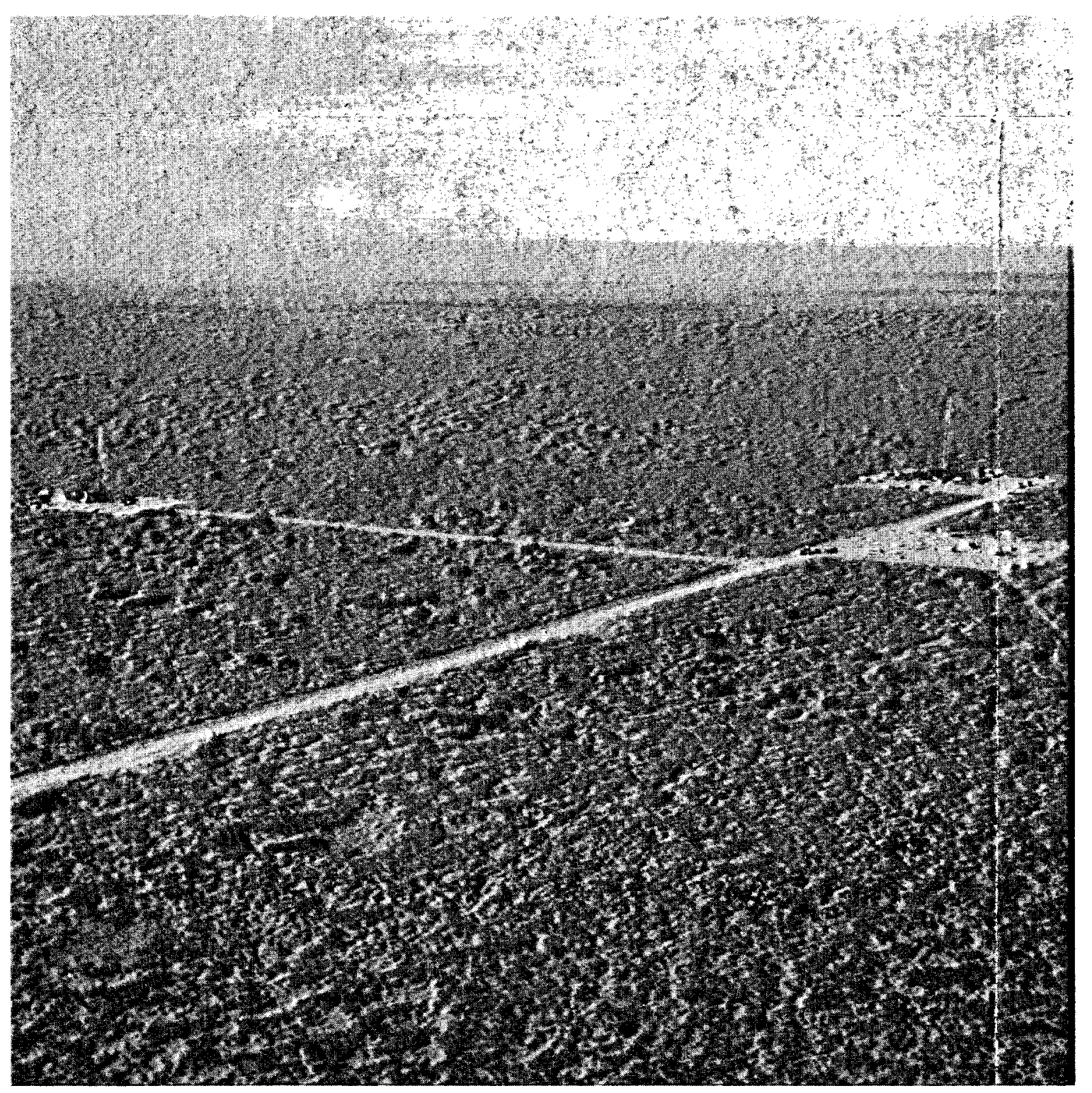

AIR VIEW ACROSS WIPP SITE

View is to the
H-1 (far left).

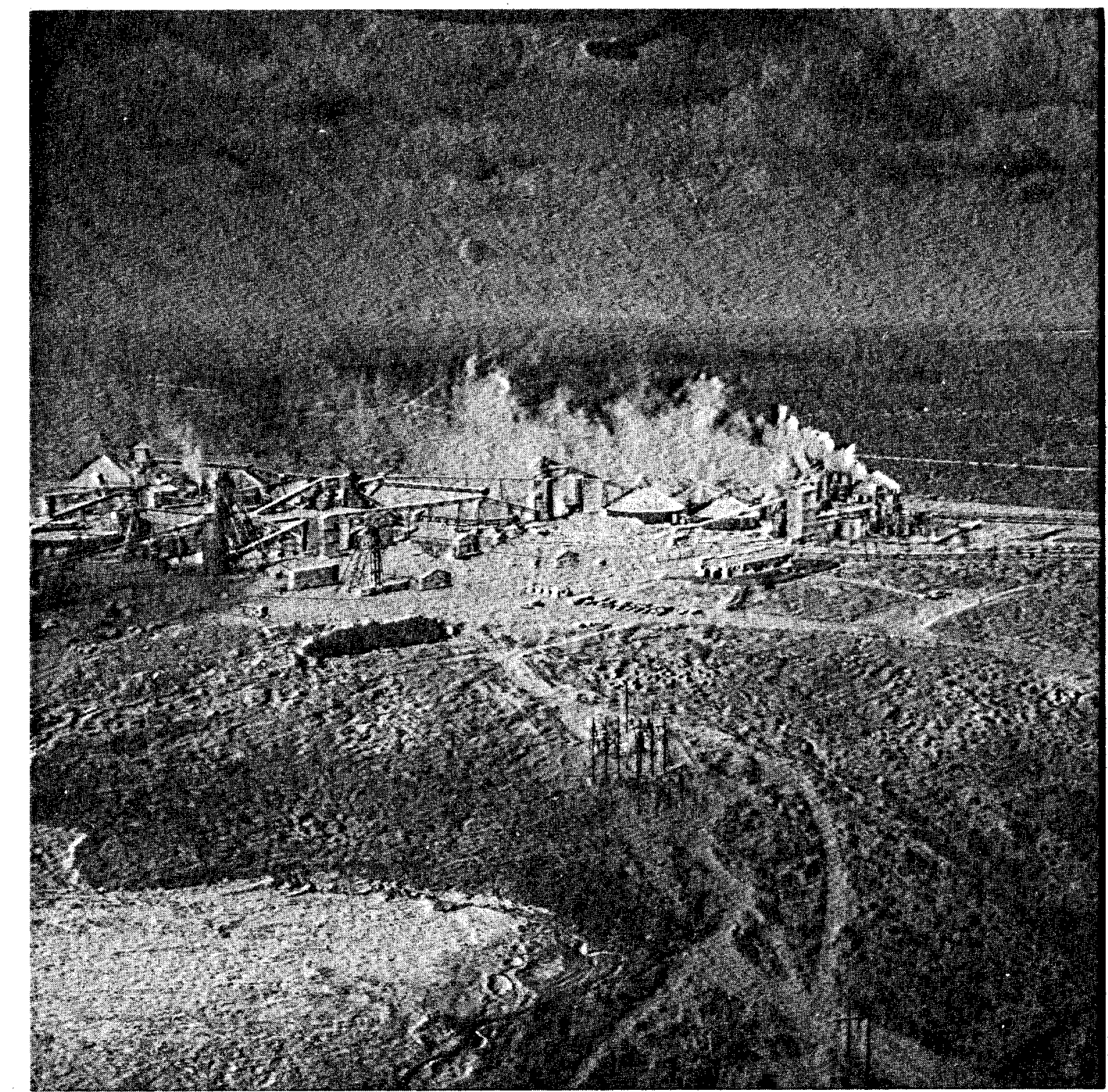

POTASH REFINERY

Owned by Duval Corporation located 20 miles west of Carlsbad.

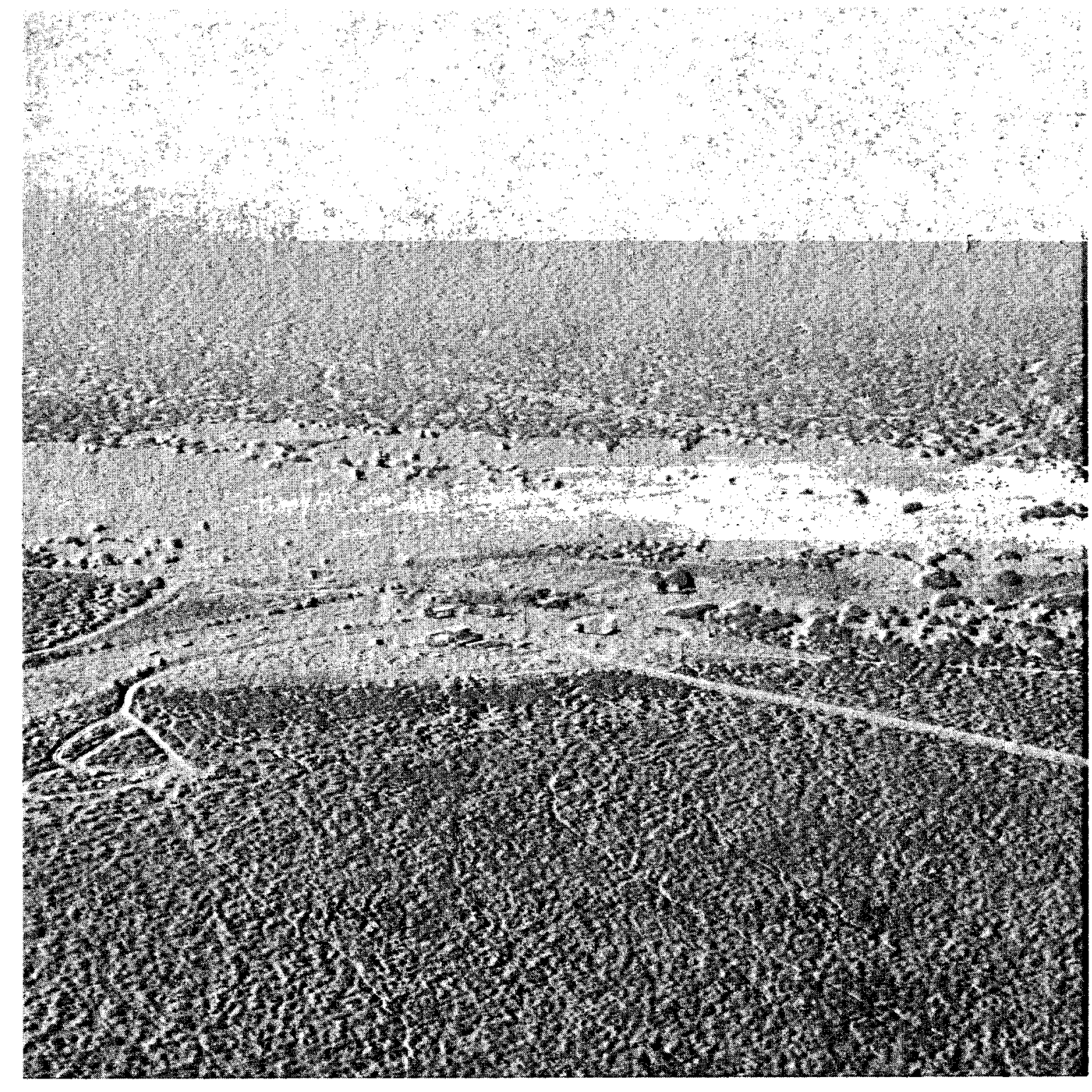

JAMES RANCH HEADQUARTERS

Located 3 miles south of the site. Note active sand dunes. View is to the southeast.

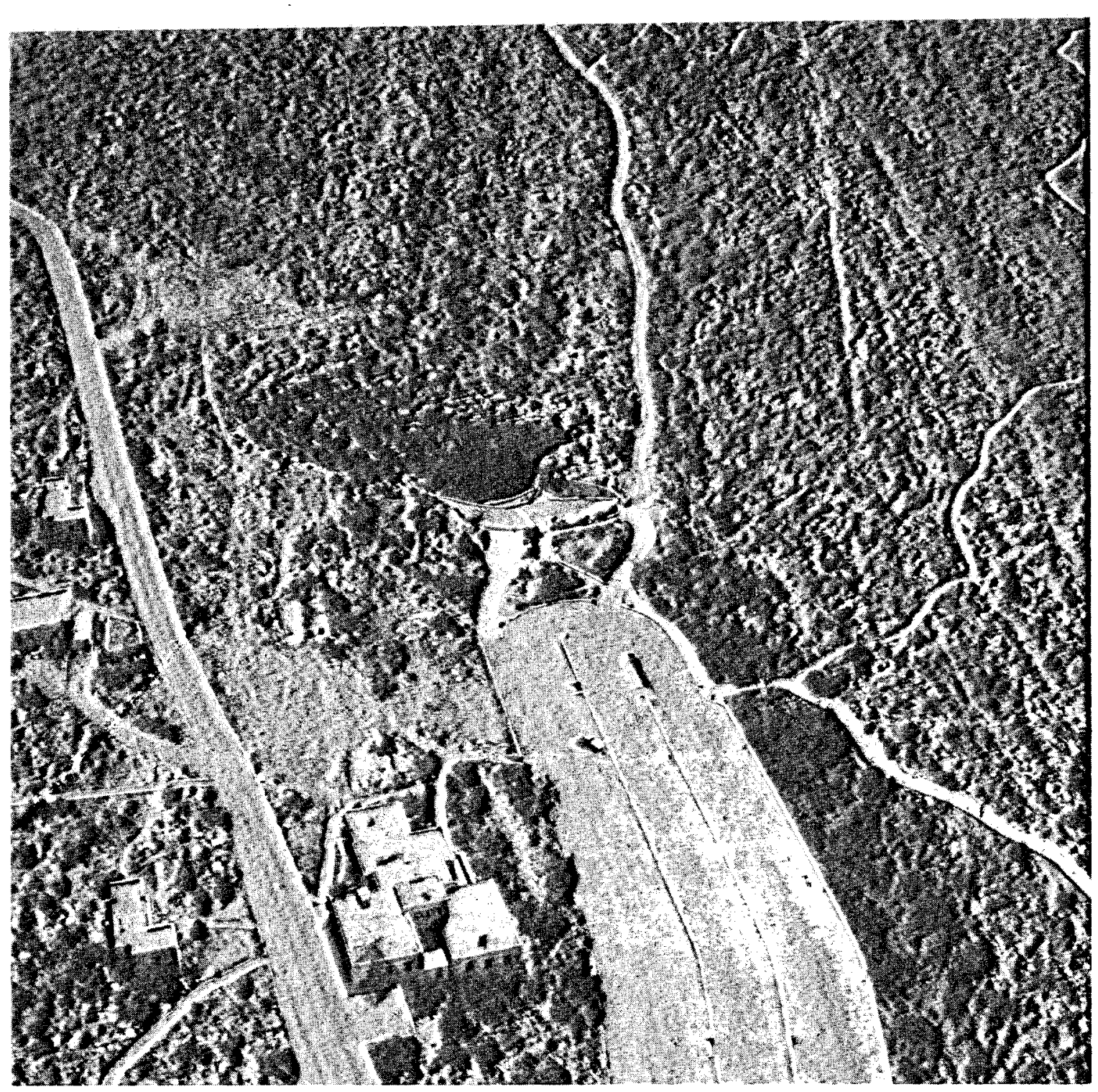
Carlsbad caverns

Loca.
site.

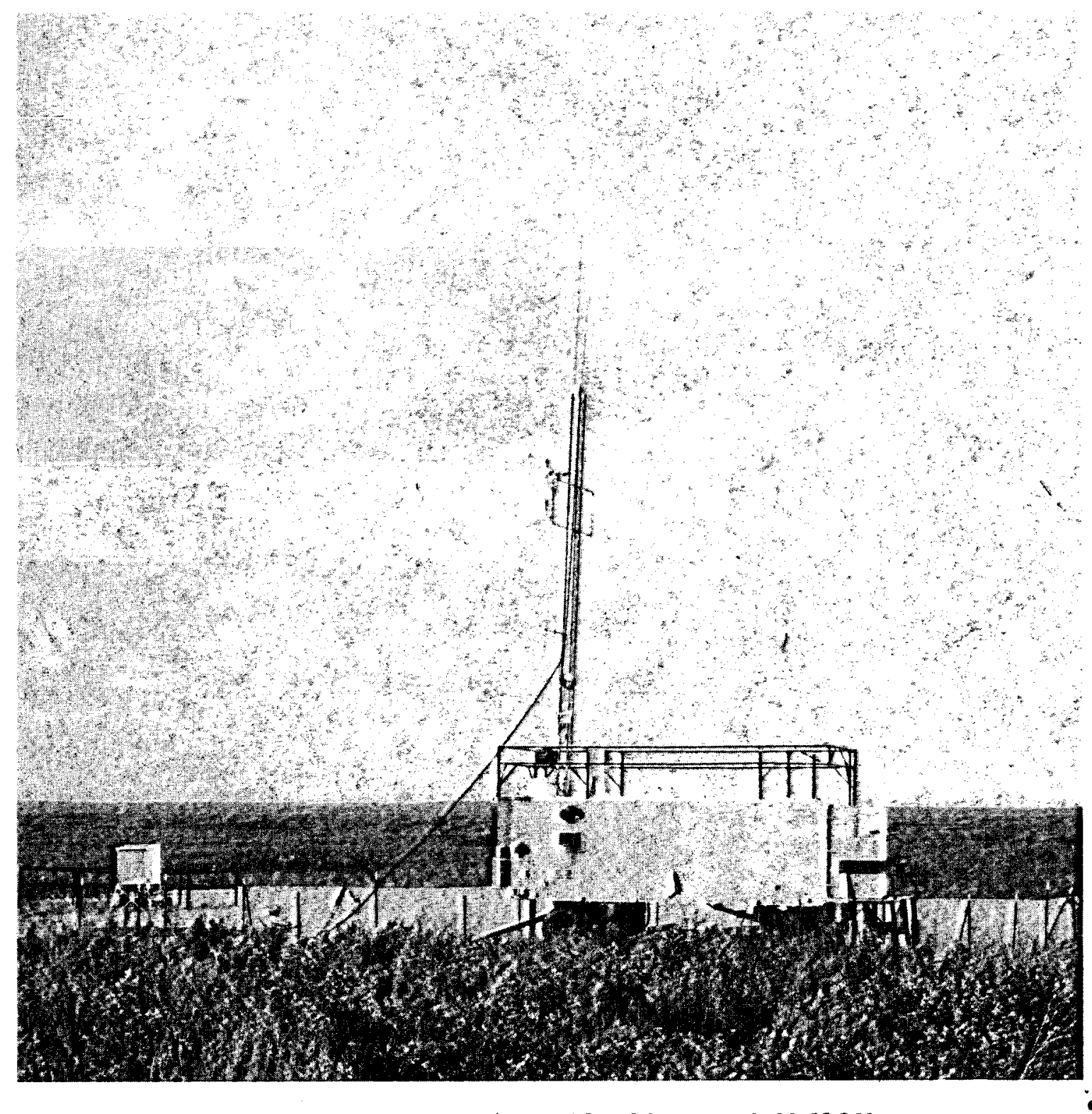

TEMPORARY METROLOGICAL STATION

This station was located at AEC No. 7 drill location. A new station has been erected

FIGURE 33 